\title{
Performance of a Wastewater Treatment Pond System with Microfiltration
}

\author{
A Master's Thesis Presented to the Faculty of \\ California Polytechnic State University \\ San Luis Obispo
}

\author{
In Partial Fulfillment \\ Of the Requirements for the Degree \\ Master of Science in \\ Civil and Environmental Engineering
}

By

Eric Martin

December 2012 
(C) 2012

Eric Martin

ALL RIGHTS RESERVED 


\section{AUTHORIZATION FOR REPRODUCTION OF MASTER'S THESIS}

I hereby grant permission for the reproduction of this thesis in its entirety or any of its parts, without further authorization, provided acknowledgment is made to the authors and advisors.

Eric Martin

Date 


\section{APPROVAL PAGE}

TITLE: Performance of a Wastewater Treatment Pond System with Microfiltration AUTHOR: Eric Martin

DATE SUBMITTED: December 2012

Committee Chair: $\quad$ Dr. Tryg Lundquist

Committee Member: $\quad$ Dr. Yarrow Nelson

Committee Member: $\quad$ Dr. Sam Vigil 


\title{
ABSTRACT \\ PERFORMANCE OF A WASTEWATER TREATMENT POND SYSTEM WITH MICROFILTRATION
}

\author{
Eric Martin
}

The Woodlands Wastewater Treatment Plant (WWWTP) treats wastewater from the Woodlands housing community near Nipomo, California. The treated effluent is recycled for irrigation of a golf course within the community. The treatment facility consists of three facultative ponds in series followed by a microfiltration system and chlorine disinfection. Microfiltration of wastewater pond effluent is a fairly new, and potentially challenging, application of microfiltration. This thesis describes the operating conditions and behavior of the WWWTP pond system followed by a microfiltration system for the purpose of producing recyclable water fit for reuse under the regulations of Title 22.

Water quality data were compiled in two ways. Weekly influent and effluent water quality and flow measurements conducted by the WWWTP operators over the course of three years were studied to show the treatment trends of the treatment plant as a whole. In addition, weekly water quality tests were performed on samples of wastewater influent, effluent, and intermediate stages of treatment for 20 weeks and studied to show treatment performance of each individual pond and the microfiltration system. Pond treatment performance was analyzed based on removal of biochemical oxygen demand (BOD) and total suspended solids (TSS) and accumulation of sludge within the pond system. Microfiltration performance was analyzed in terms of meeting 
the TSS discharge requirement and the membrane fouling rate. The power consumption of the pond system components and the microfiltration system were estimated.

The data show that the WWWTP is producing very high quality discharge. Without microfiltration, five-day carbonaceous soluble BOD $\left(\operatorname{csBOD}_{5}\right)$ averaged $3.0 \mathrm{mg} / \mathrm{L}$ and TSS averaged $42.5 \mathrm{mg} / \mathrm{L} . \mathrm{BOD}_{5}$ and TSS removal efficiencies were greater than $90 \%$. Microfilter effluent $\mathrm{BOD}_{5}$ and TSS concentrations averaged $3.0 \mathrm{mg} / \mathrm{L}$ and $1.6 \mathrm{mg} / \mathrm{L}$, respectively. Total ammonia nitrogen was reduced to $1.61 \mathrm{mg} / \mathrm{L}$. $\mathrm{pH}$ remained between 6.5 and 8.5 with few temporary exceptions. The sludge accumulation was at the high end of the range of typical accumulation rates. However, the measured rate is for the first three years of operation and so likely over-estimates the long-term accumulation rate. Although the treatment performance of the WWWTP is excellent, the power consumed was high. 


\section{ACKNOWLEDGMENTS}

To Dr. Tryg Lundquist

Thank you for your support, guidance, and willingness to be available to your students who would not succeed if not for your guidance and knowledge in the area of study that we have endeavored to learn.

To Dr. Yarrow Nelson and Dr. Sam Vigil

Thank you for support, your time, and your willingness to be available. Success would not have been possible without your contribution.

To Jenny Struthers, Mike Wentzel, and and Scott Ryczek at Fluid Resource Management. Thank you for your willingness, your knowledge, and your patience for my studies. Without your consistent help with the treatment plant operations, this would not have been possible.

Thank you to Rob Miller at Wallace Group, San Luis Obispo who helped arrange access to the site.

To my undergraduate lab technicians: Jennifer Shedden, Christos Mavrakis, Miles Johnson, Shauna Falvey, Katie Rollins, and Samantha August.

Thank you for your time and dedication and help in my attempt to teach and manage a successful laboratory.

To my parents Todd and Julie, and my family, Thank you for your support and confidence throughout this process. This is all possible because of the encouragement you regularly gave when I needed it most. 


\section{TABLE OF CONTENTS}

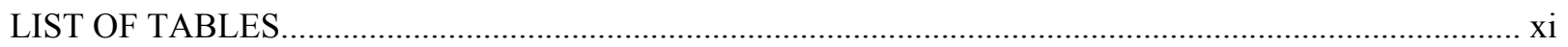

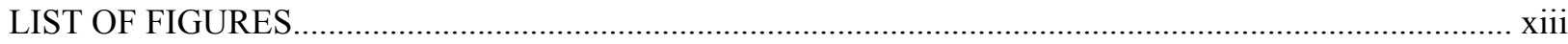

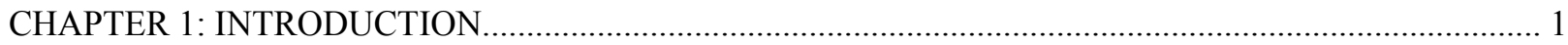

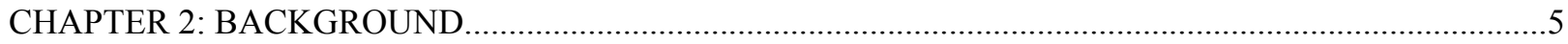

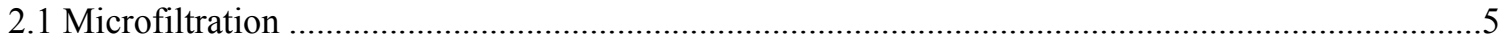

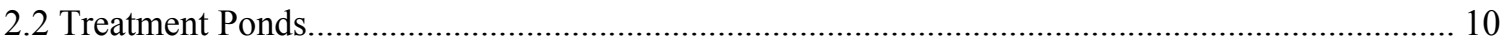

CHAPTER 3: POND TREATMENT CHARACTERISTICS................................................................ 13

3.1 Short History of the Woodlands Wastewater Treatment Plant..................................................... 13

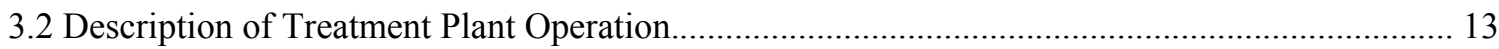

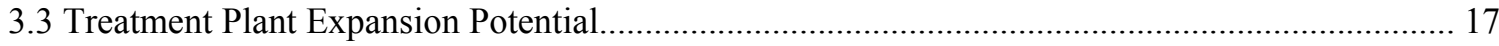

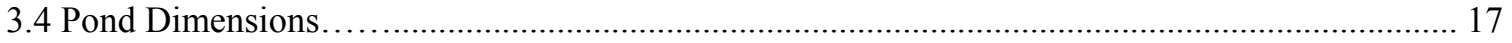

3.5 Flow Characteristics................................................................. 19

3.6 Load Characteristics.............................................................. 20

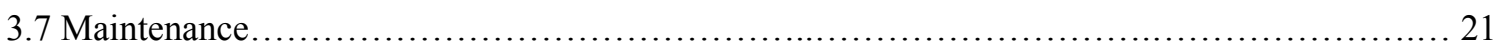

3.8 Regional Water Quality Control Board Regulations .................................. 23

CHAPTER 4: MICROFILTER CHARACTERISTICS ............................................... 24

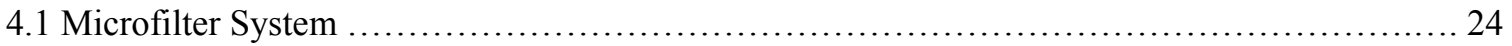

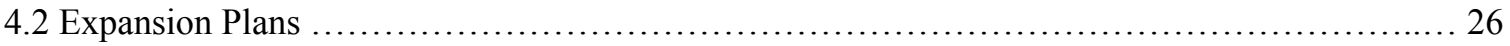

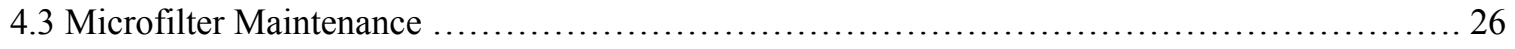

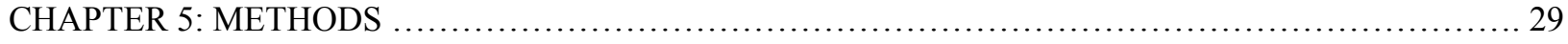

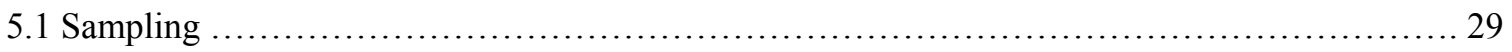

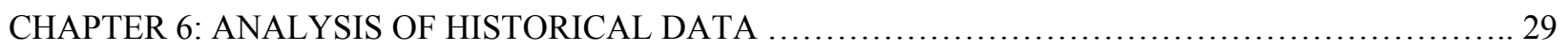

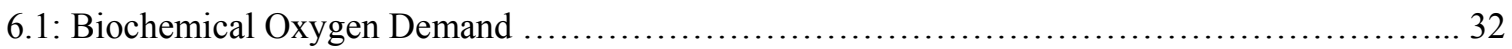

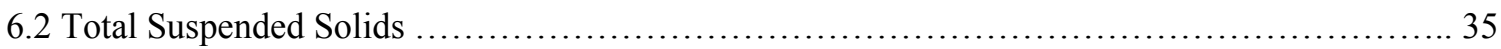

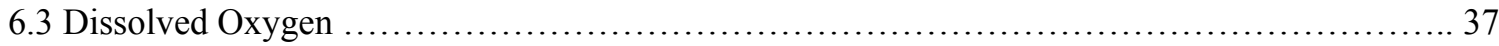




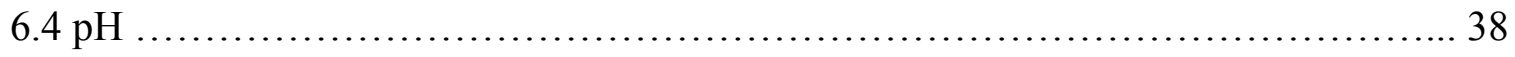

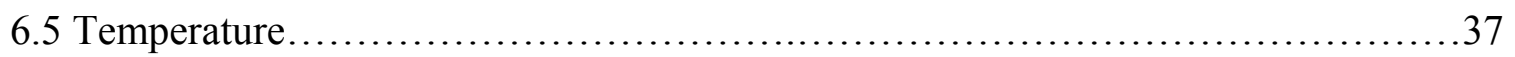

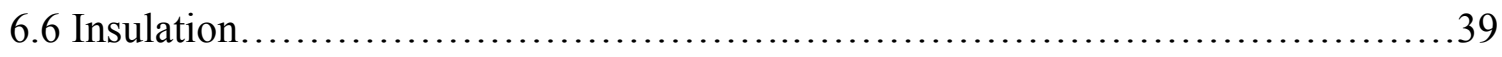

6.7 Analysis of Historical Data and Conclusion.......................................40

CHAPTER 7: ANALYSIS: A CLOSER LOOK AT WATER QUALITY .................... 42

7.1 Biochemical Oxygen Demand .............................................. 42

7.2 Total Suspended Solids ...................................................... 46

7.3 Total Ammonia Nitrogen ................................................. 48

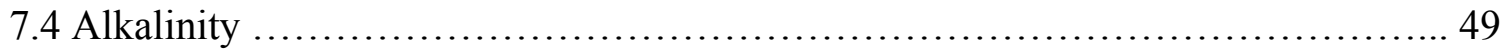

7.5 Sludge Production ........................................................... 50

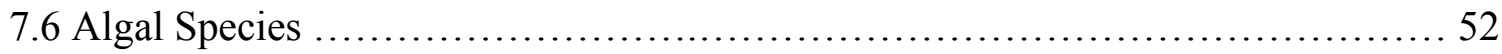

7.7 Microfiltration ............................................................. 54

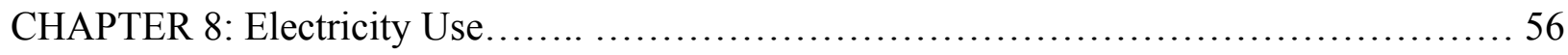

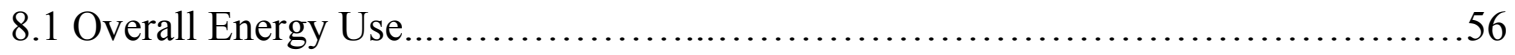

8.2 Aeration Energy Use........................................................ 57

8.3 Estimated Energy Use by Equipment.......................................... 58

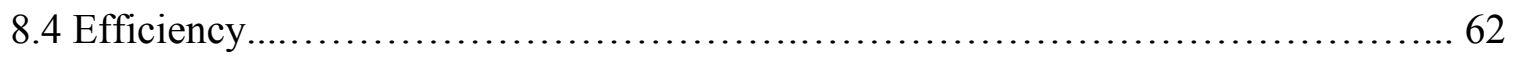

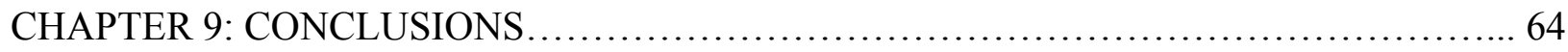

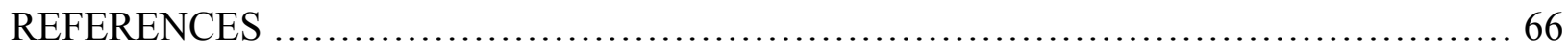

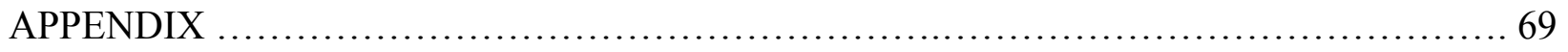




\section{LIST OF TABLES}

Table

Page

1.1 Limits set by the RWQCB for discharge effluent (Water Quality Permit).

"BOD" indicates $\mathrm{tBOD}_{5}$ limits

2.1 Membrane types, pore sizes, and contaminants commonly removed

3.1 Full volumes and approximate dimensions of the ponds. The water surface width and length are given. Digester pits are two feet deeper than recorded depth. The treatment portion of Pond $\mathrm{C}$ and the maturation portion of Pond $\mathrm{C}$ have a combined volume of $1.75 \mathrm{MG}$. Volumes were given in the plant specifications

3.2 Volume in millions of gallons (MG) and retention time for each pond and the total pond system, with a 25,000 gallon per day average flow

3.3 Dissolved oxygen set-points for automatic aerator operation in each pond at the WWWTP

3.4 The effluent water quality requirements of the Woodlands treatment facility set by the RWQCB

4.1 Caustic and acidic additions to rinse water during chemical cleaning

6.1 Summary of effluent characteristics of the WWWTP $\left(\mathrm{tBOD}_{5}, \mathrm{TSS}, \mathrm{DO}\right.$ and $\mathrm{pH}$ from March 2009 to March 2012 and comparison to regulations set by the RWQCB

7.1 Data of $\operatorname{csBOD}_{5}$ for Pond A, B, C, and the microfilter from September 2011 to March 2012

7.2 Summary of $\mathrm{csBOD}_{5}$ data collected from September 2011 to March 2012. Note that the detection limit for BOD is $1 \mathrm{mg} / \mathrm{L}$

7.3 Summary of kinetic parameters and soluble carbonaceous $\mathrm{BOD}_{5}$ removal efficiency determined from the average data collected during September 2011 to March 2012

7.4 Summary of TSS data collected from September 2011 to March 2012 48

7.5 Summary of TAN data collected from September 2011 to March 2012 
7.6 Summary of ALK data collected from September 2011 to March 2012 ........... 50

7.7 Measured sludge accumulation rates compared to typical ranges in the WWWTP system from March 2009 to March 2012

8.1 WWWTP energy consumption and cost for each month of the year of $2011 \ldots \ldots 5$

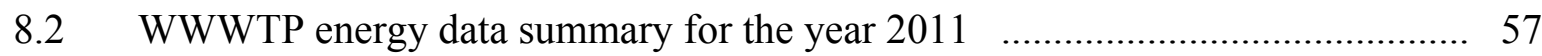

8.3 Summary of aerator motor nameplate power and operating settings in each pond at the WWWTP 58

8.4 Aerator and Microfilter energy estimates and costs per year during the months of March 2009 and March 2012

8.5 Summary of the performance of WWWTP and those treatment plants included in the study by PG\&E (Benschine et al. 2003)

9.1 Treatment pond and microfilter performance of $\mathrm{BOD}_{5}$ and TSS and associated costs of operation at the WWWTP 


\section{LIST OF FIGURES}

Figure

Page

1.1 Location of Woodlands Wastewater Treatment plant in Nipomo California, approximately 30 miles south of San Luis Obispo (Google Maps).............. 2

1.2 Layout diagram of wastewater treatment plant showing flow through plant operations 3

2.1 Sizes of common water constituents and pore sizes of membrane filters $\ldots \ldots \ldots .6$

2.2 Electron micrographs of a PVDF membrane. The pores have a nominal size

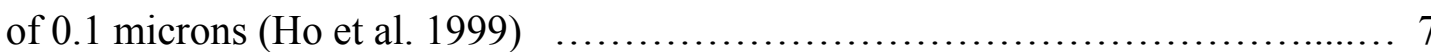

2.3 Diagram showing the symbiotic relationship between bacteria and algae with the products and constituents of each process. (Oswald et al. 1955)

3.1 Photo of layout of the Woodlands wastewater treatment plant with labeled treatment unit operations

3.2 Headworks of the WWWTP. Below the grate, a grinder reduces waste to small particles and a screen separates and disposes of debris before it enters the pond system

3.3 Pond A seen from the influent end of pond facing southwest $\ldots \ldots \ldots \ldots \ldots \ldots \ldots . \ldots \ldots$

3.4 Pond B seen from the influent end of pond facing northwest $\ldots \ldots \ldots \ldots \ldots \ldots \ldots$

3.5 Left: Pond C from influent end. Right: Pond C looking down at a maturation (un-aerated) zone of pond $\mathrm{C}$. Maturation zone in relation to Pond $\mathrm{C}$ can be seen in Figure 1.2

3.6 Topographical Plan of the three treatment ponds with pond depth and digester depth shown. Proposed ponds can be seen in the center of the current ponds and treatment plant facility

3.7 Topographical plan of the three treatment ponds. Proposed ponds can be seen in the center of the current ponds and treatment plant facility

3.8 Schematic of the treatment ponds and the Horizontal Rotor Aerators in Ponds

$\mathrm{A}, \mathrm{B}$, and $\mathrm{C}$

4.1 Right: Microfilter skid containing 30 microfilter modules. Each filter module is filled with hollow fiber tube filters. Left: Pall Brand Aria AS series control 
module

4.2 The Pall Aria AP-4 series used at the Woodlands wastewater treatment facility is similar to the one shown above. Left: A system with five modules. Right: cross section of single module with hollow fibers

5.1 Photographs of locations of sample collection. (a) Influent flume. (b) Pond A effluent weir. (c) Pond B effluent weir. (d) Pond 3 collection box. (e) Microfilter effluent spigot. (f) Microfilter backwash 30

6.1a Total $\mathrm{BOD}_{5}$ in the influent and effluent of the WWWTP from March 2009 through March 2012, as reported in monthly reports to the RWQCB

6.1b Total $\mathrm{BOD}_{5}$ influent and effluent of the WWWTP from March 2009 through March 2012, as reported in monthly reports to the RWQCB. Y-axis scale has been changed to omit the highest measurements in order to show more detail in the typical influent range

6.1c Total $\mathrm{BOD}_{5}$ concentration of plant effluent from January 2009 to March 2012. The increase in BOD effluent concentration was reported by the operators to be the result of acetic acid addition to the microfilter effluent in the chlorine contact basin for $\mathrm{pH}$ control

6.2a TSS influent and effluent of the WWWTP from March 2009 through March 2012, as reported in monthly reports to the RWQCB

6.2b TSS influent and effluent of the WWWTP from March 2009 through March 2012, as reported in monthly reports to the RWQCB. Y-axis scale has been changed to omit the highest measurements in order to show more detail in the typical influent range

6.2c TSS effluent of the WWWTP from March 2009 through March 2012, as reported in monthly reports to the RWQCB

6.3 Effluent dissolved oxygen effluent of the WWWTP from March 2009 through March 2012, as reported in monthly reports to the RWQCB

6.4 Effluent pH of the WWWTP from March 2009 through March 2012, as reported in monthly reports to the RWQCB

6.5 Monthly ambient temperature recordings from CIMIS Station 202 in Nipomo 
6.6: Insulation monthly recordings from CIMIS station 202 in Nipomo California ...

7.1a $\operatorname{csBOD}_{5}$ at various locations at the WWWTP from September 2011 through March 2012. Locations include influent (total $\mathrm{BOD}_{5}$ ), influent (carbonaceous soluble BOD 5 ), Pond A effluent, Pond B effluent, Pond C effluent, microfilter effluent, and the microfilter backwash outlet to Pond A

7.1b Soluble carbonaceous $\mathrm{BOD}_{5}$ at various locations at the WWWTP from September 2011 through March 2012. Locations include Pond A effluent, Pond B effluent, Pond C effluent, and microfilter effluent

7.2 TSS at various locations at the WWWTP from September 2011 through March 2012. The sample locations were the Influent, Pond A effluent, Pond B effluent, Pond $\mathrm{C}$ effluent, and microfilter effluent

7.3 VSS at various locations at the WWWTP from September 2011 through March 2012. The sample locations include Influent, Pond A effluent, Pond B effluent, Pond $\mathrm{C}$ effluent, and microfilter effluent

7.4 Total ammonia nitrogen (TAN; $\mathrm{NH}_{3}+\mathrm{NH}_{4}{ }^{+}$) at various locations at the WWWTP from September 2011 through March 2012. Locations include Influent, Pond A effluent, Pond B effluent, Pond C effluent, and microfilter effluent

7.5 Alkalinity as $\mathrm{mg} / \mathrm{L} \mathrm{CaCO}_{3}$ at various locations at the WWWTP from September 2011 through March 2012. Locations include Influent, Pond A effluent, Pond B effluent, Pond C effluent, and microfilter effluent

7.6 Sludge depth diagram of 22 depth locations in the pond system at the Woodlands Wastewater Treatment Plant

7.7 Identification of algae present in the effluent of Pond C on June 5, 2012

7.8 TSS influent and effluent of the WWWTP microfilters from September 2011 through March 2012, as recorded in monthly reports to the RWQCB. All data points shown as $1 \mathrm{mg} / \mathrm{L}$ were recorded as $<1 \mathrm{mg} / \mathrm{L}$ in the monthly report

7.9 TSS effluent of the WWWTP microfilters from March 2009 through March 2012, as reported in monthly reports to the RWQCB. All data points shown as $1 \mathrm{mg} / \mathrm{L}$ were reported as $<1 \mathrm{mg} / \mathrm{L}$ in the monthly reports 
A.2 Elevation plan view of Pond A. Digester floor and pond floor elevations are displayed on image

A.3 Elevation plan view of Pond B. Digester floor and pond floor elevations are displayed on image

A.4 Elevation plan view of Pond C. Pond floor elevations are displayed on image .... 72

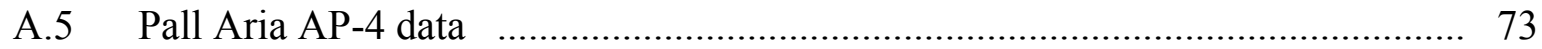

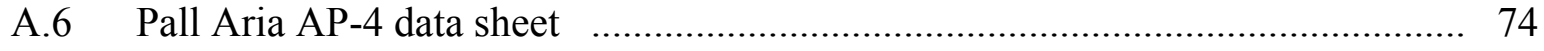




\section{CHAPTER 1: INTRODUCTION}

Wastewater treatment pond systems are a common technology throughout the world. Most municipal pond systems in the US treat to the secondary level, achieving removal of organic matter (USEPA 2003) and some incidental removal of pathogens and nutrients. Chlorine disinfection is often applied before discharge or reuse. At many pond facilities producing water for reuse, filtration is also applied, often using granular media filtration. Low levels of suspended solids are often required for effluent recycling for irrigation. Use of microfiltration to improve algae pond effluents is currently rare. Reasons for this may include the relatively recent application of microfiltration to wastewater, its cost, and inexperience with the fouling rate of microfilters subjected to pond effluents. In particular, the effluent of many pond systems contains high concentrations of suspended microalgae, which can be expected to accelerate fouling. Microfiltration has been more commonly applied to water supply treatment and not wastewater pond effluent treatment. Increased frequency of backwashing, membrane cleaning, and membrane replacement are cost factors that need to be better understood for wastewater applications. The present thesis research sought to better characterize pond-microfilter treatment by collecting water quality data at such a facility and using it to evaluate the performance of both the microfilter and the overall pond-microfilter combination. In addition to water quality and microfilter operations issues, the energy efficiency of the overall process was assessed. The WWWTP near Nipomo California, was used as a case study for this thesis. The water quality constituents studied were biochemical oxygen demand, suspended solids, total ammonia nitrogen, alkalinity, $\mathrm{pH}$, temperature, and dissolved oxygen. Although the subject facility was not intended for nutrient removal, ammonium removal was extensive. 
The Woodlands Wastewater Treatment Plant (WWWTP) is a secure facility located off of Highway 1 at Professional Parkway and Via Entrada within the Woodlands housing community near Nipomo, California (Figure 1.1). The WWWTP treated effluent is used to irrigate the nearby golf course.

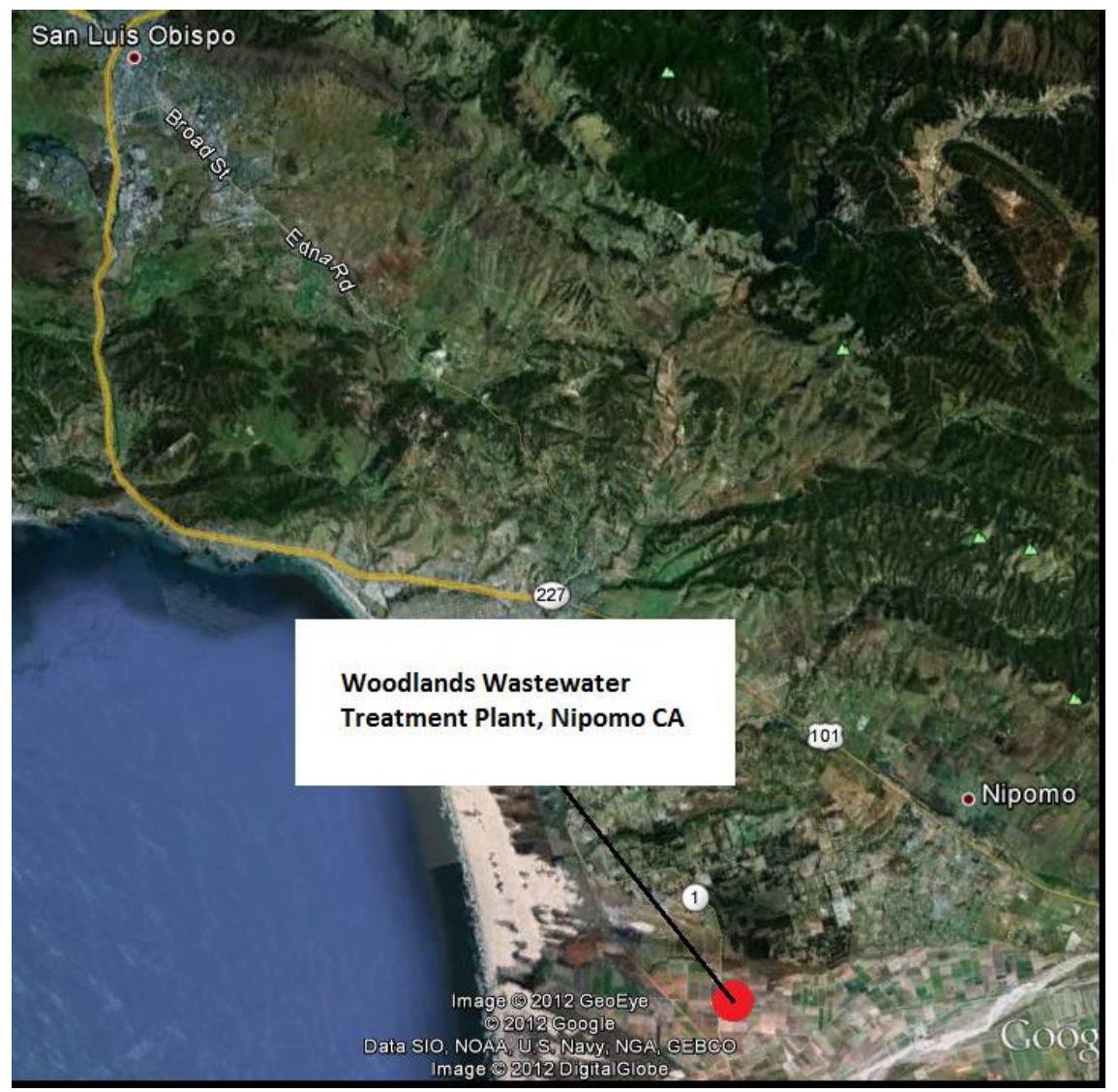

Figure 1.1: Location of Woodlands Wastewater Treatment plant in Nipomo California, approximately 30 miles south of San Luis Obispo (Google Maps).

The wastewater treatment plant processes wastewater first by three facultative ponds, and then by microfiltration and chlorination. Treatment unit operations are listed here and shown in Figure 1.2

1. Headworks: grinder, screen, solids auger

2. Ponds A-C: three aerated facultative ponds in series

3. Microfilter: Pall Brand Aria AP-4 in operations building

4. Chlorine contact basin 


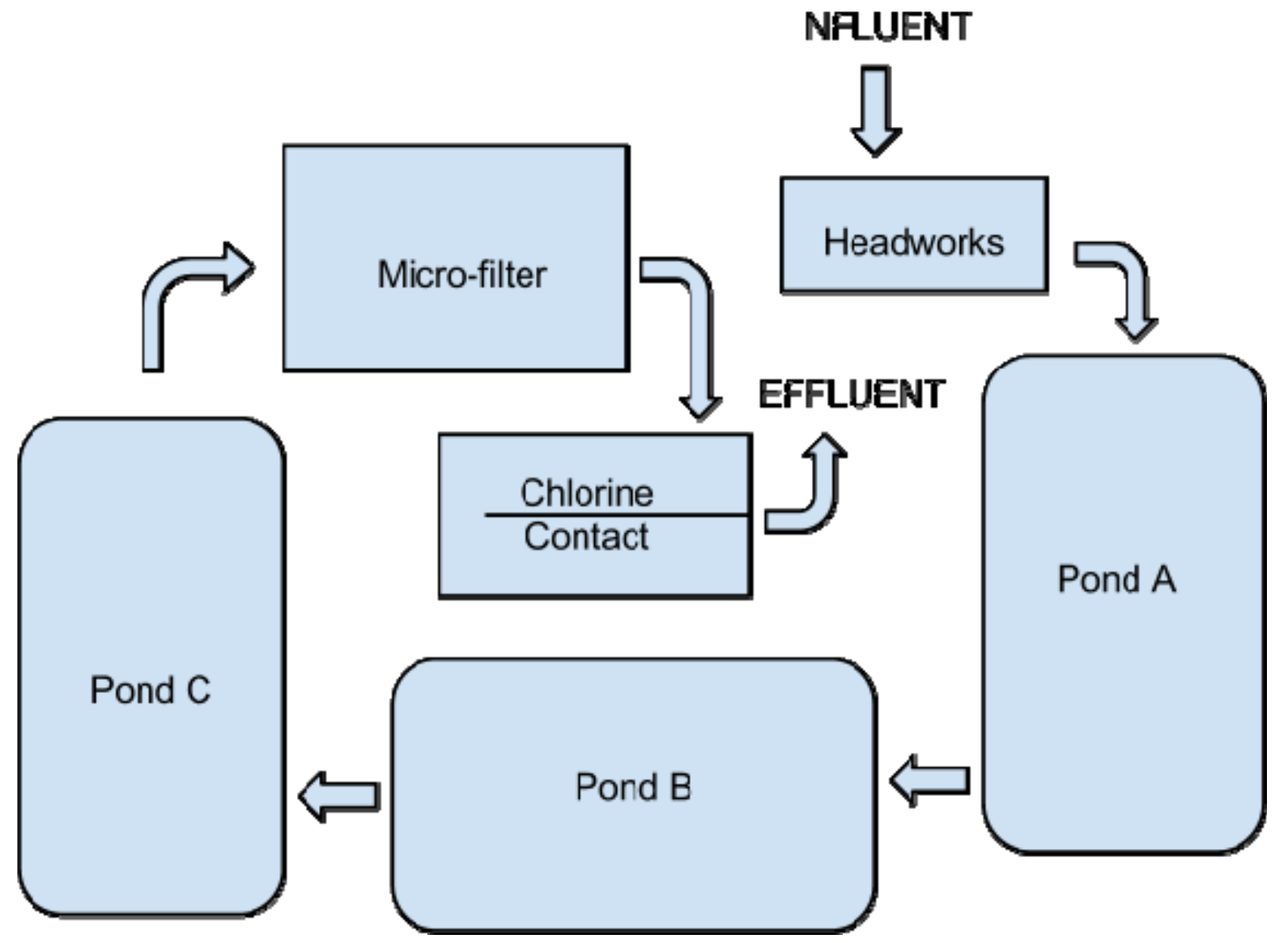

Figure 1.2: Schematic layout diagram of wastewater treatment plant showing flow through plant operations.

Table 1.1: Limits set by the RWQCB for discharge effluent. "BOD” indicates total $\mathrm{BOD}_{5}$ including the nitrogenous $\mathrm{BOD}_{5}$ component.

\section{Effluent Limits}

\begin{tabular}{l|c|c|c|}
\hline Parameter & Units & Mean & Max \\
\hline BOD & $\mathrm{mg} / \mathrm{l}$ & 10 & 30 \\
\hline Suspended Solids & $\mathrm{mg} / \mathrm{l}$ & 10 & 30 \\
\hline Settleable Solids & $\mathrm{ml} / \mathrm{l}$ & 0.1 & 0.3 \\
\hline Turbidity & $\mathrm{NTU}$ & $2^{\star}$ & $5^{\star \star}$ \\
\hline TDS & $\mathrm{mg} / \mathrm{l}$ & & 710 \\
\hline $\mathrm{pH}$ & \multicolumn{2}{|c|}{ Within range of 6.5 to 8.4} & \\
\hline
\end{tabular}


The goal of this thesis is to characterize the treatment conditions and performance of the WWWTP in its objective to provide secondary treated reclaimed water to the Woodlands community. The main questions to be answered are listed below.

1. Does the WWWTP remove $\mathrm{BOD}_{5}$ to below the limit of $10 \mathrm{mg} / \mathrm{L}$ (Table 1.1)?

2. Does the WWWTP remove TSS to below the limit of $10 \mathrm{mg} / \mathrm{L}$ (Table 1.1)?

3. Does the WWWTP provide effluent with $\mathrm{pH}$ that falls within the allowable range (Table $1.1) ?$

4. How effective is the WWWTP at removing nitrogen? (The RWQCB does not require nitrogen removal at this plant.)

5. How much sludge is accumulating in the pond system?

6. Has there been any permanent fouling of the microfiltration membranes?

7. How does the energy intensity of the WWWTP compare to activated sludge plants?

Chapter 2 reviews microfilter technology and treatment pond characteristics typical to wastewater treatment, and Chapter 3 describes the WWWTP in some detail. 


\section{CHAPTER 2: BACKGROUND}

\subsection{Microfiltration}

"Membrane filtration is defined as a pressure- or vacuum-driven separation process in which particulate matter larger than $1 \mu \mathrm{m}$ is rejected by an engineered barrier, primarily through a size exclusion mechanism, and which has a measurable removal efficiency of a target organism that can be verified through the application of a direct integrity test" (USEPA 2005).

Membranes that are used in the treatment of water and their approximate respective pore sizes are listed in Table 2.1 and shown in Figure 2.1. Microfiltration is used to filter particulates with nominal pore size of $0.1 \mu \mathrm{m}$ to $1 \mu \mathrm{m}$.

Table 2.1: Membrane types, pore sizes, and contaminants commonly removed. (USEPA 2005).

\begin{tabular}{lcc}
\hline $\begin{array}{l}\text { Treatment } \\
\text { Membrane }\end{array}$ & $\begin{array}{c}\text { Approximate Pore Size Range } \\
(\mu \mathbf{m})\end{array}$ & Commonly used to remove \\
\hline Microfiltration & $0.1-1$ & Bacteria, algae, protozoan cysts \\
Ultrafiltration & $0.01-0.1$ & Viruses, colloids \\
Reverse Osmosis (RO) & $0.05-0.0001$ & Most ions \\
\hline
\end{tabular}




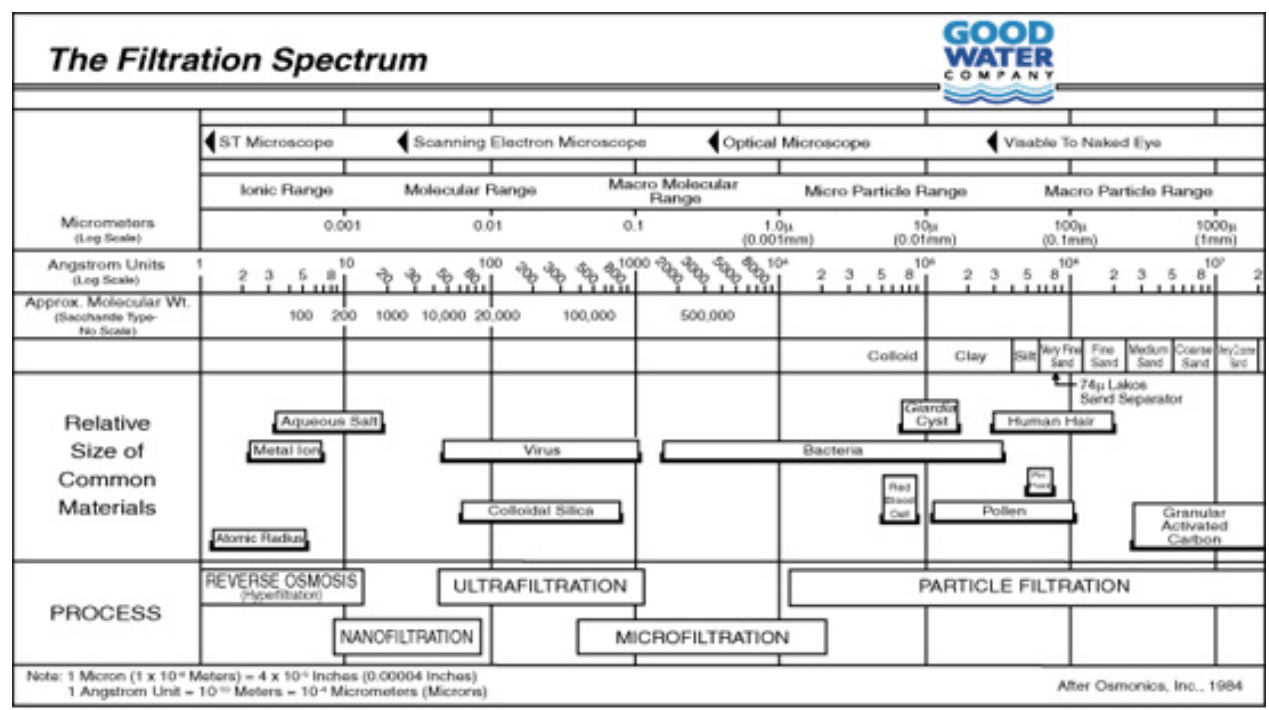

Figure 2.1: Sizes of common water constituents and pore sizes of membrane filters (Good Water Company 2012).

The microfiltration system used at the WWWTP is the Pall Brand Aria AP-4 microfiltration system and has a nominal pre size of $0.1 \mu \mathrm{m}$. The Aria AP-4 is a olyvinylidene difluoride (PVDF) hollow fiber membrane (Figure 2.2). The patent for the hollow fiber PVDF describes the PVDF as follows: "having a high selectivity in permeation, a high permeability, a high porosity, an excellent mechanical strength and an excellent chemical resistance and an excellent inertness to living bodies" (Nohmi et al. 1981). Figure 2.2 below shows a micrograph of a PVDF membrane. 


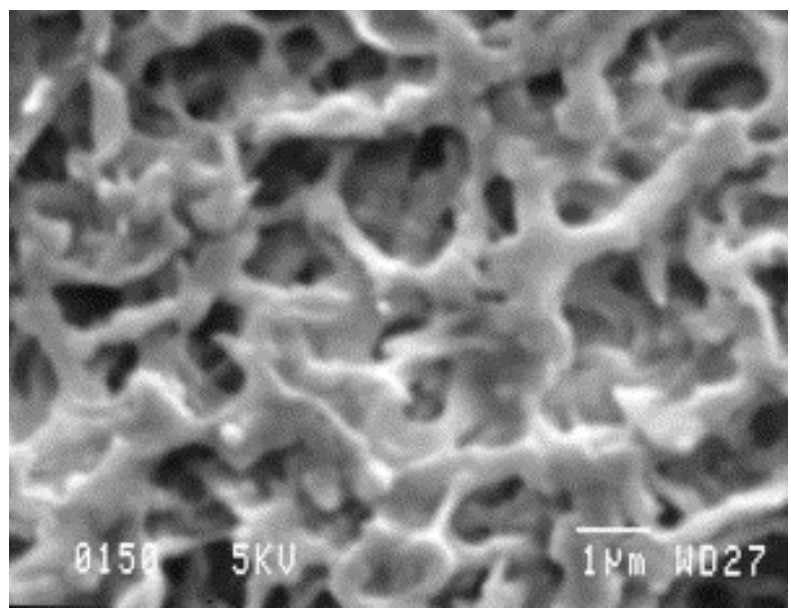

Figure 2.2: Electron micrographs of a PVDF membrane. The pores have a nominal size of 0.1 microns (Ho et al. 1999).

The pores of the PVDF membrane are very regular or similarly sized throughout the structure. The contaminants in the wastewater are captured by the membrane matrix and removed from the waste stream. Due to the porous nature of the structure, particles are likely to be lodged in the structure, potentially clogging the filter and hindering performance. Membrane clogging occurs when the physical obstructions to the membrane become too great for productive filtration. Biofouling occurs when a buildup of microorganisms decreases the flux through the membrane. Deterioration of flux through the membrane must be periodically prevented in order to prevent clogging and preserve the life of the filter membrane. If measures are not taken to prevent cake formation on the membrane surface, the filter flux through the membrane will decrease or transmembrane pressure will have to be increased to maintain the same flow.

Periodic backwashes and chemical cleanings are standard procedures to maintain microfiltration performance, but other methods of preventing permanent fouling of microfilters are being explored. One study (Fabris et al. 2007) examined the effects of pretreatments of the feed stream to decrease the effects of natural organic matter (NOM) on microfilter biofouling. They found 
that removal of colloidal suspensions and dissolved organic carbon (DOC) helped prevent biofouling of a microfilter. The removal of colloids with pretreatment included the use of a magnetic ion exchange resin or MIEX (Orica Australia Pty. Ltd.), followed by the addition of aluminum sulfate (alum), then powdered activated carbon (PAC), and alum again. Before MIEX treatment, coagulated colloids and DOC are removed by settling in order to increase the life of the microfilter. This study found that by nearly completely eliminating the concentration of DOC and colloids in the feed stream, biofouling could be reduced significantly in microfiltration.

One wastewater study (Ahn et al. 1999) explored the ability of hollow fiber microfiltration to process wastewater to reuse standards and found that it is capable of removing solids from wastewater so that it can be reused as irrigation. However, because wastewater has typically high levels of solids, preventative measures have to be performed more often in order to prolong the life of the filter.

Membrane filter biofouling is a major topic of research in the membrane bioreactor field, in which membranes are used to separate activated sludge suspended solids from mixed liquor. (Lim et al. 2003). It was found in this study that that the most effective way to prevent biofouling on submerged microfilter membranes in activated sludge basins is to combine a clean water backwash, sonication, and a chemical cleaning. Backwashing cleared particulates out of the membrane pores, sonication disintegrated flocculated particles that were caked on the surface of the membrane, and flushing with alkaline and acidic chemicals was needed to maintain flux. This process is not exclusively effective to activated sludge basins. 
Pretreatment is also another way to increase the life of the microfilter in wastewater reuse applications. Ferric sulfate and GAC have been shown to decrease the rate of biofouling on microfiltration of wastewater. It was found that pre-coagulation and clarification produces a flux $25 \%$ greater than a feed stream untreated (Hatt et al. 2011). The addition of $0.5 \mathrm{mg} / \mathrm{L}$ ferric sulfate, a common coagulant in the wastewater treatment industry, can increase the microfiltration flux to a constant pressure. By coagulating and clarifying the wastewater before microfiltration, the amount of solids being filtered out is less, which increases the time it takes for the solids to clog the membrane pores. Similar results were found with the addition of granular activated carbon (GAC) as a preconditioning additive to wastewater (Xing et al. 2012). By adding GAC to the microfiltration process in the feed stream followed closely by clarification prior to microfiltration, and controlling for pressure, flux was significantly increased in the fluidized bed reactor system. If the number of particles is decreased by pretreatment, flux through the microfilter is increased and the rate at which biofouling occurs is decreased (Xing et al. 2012).

No literature could be found on microfiltration of wastewater pond system effluent, and this topic provides a new opportunity for study. The treatment of pond effluent with microfiltration is the topic of this thesis, but first wastewater treatment ponds are reviewed briefly in the following section.

\subsection{Treatment Ponds}

Wastewater treatment ponds provide biological treatment of municipal waste water with a low operations cost (Metcalf and Eddy, 1991). These ponds can be designed to be heavily-loaded anaerobic ponds, less loaded facultative ponds, or lightly-loaded aerobic ponds. . In facultative 
and aerobic ponds, suspended microalgae produce photosynthetic oxygen that can be used by aerobic bacteria to remove BOD (Figure 2.3). Mechanically aerated ponds are another option, and combinations of these ponds can be joined together in systems designs. Methanogenesis is a major mechanism of treatment in anaerobic ponds and in the anaerobic benthic layer of facultative ponds.

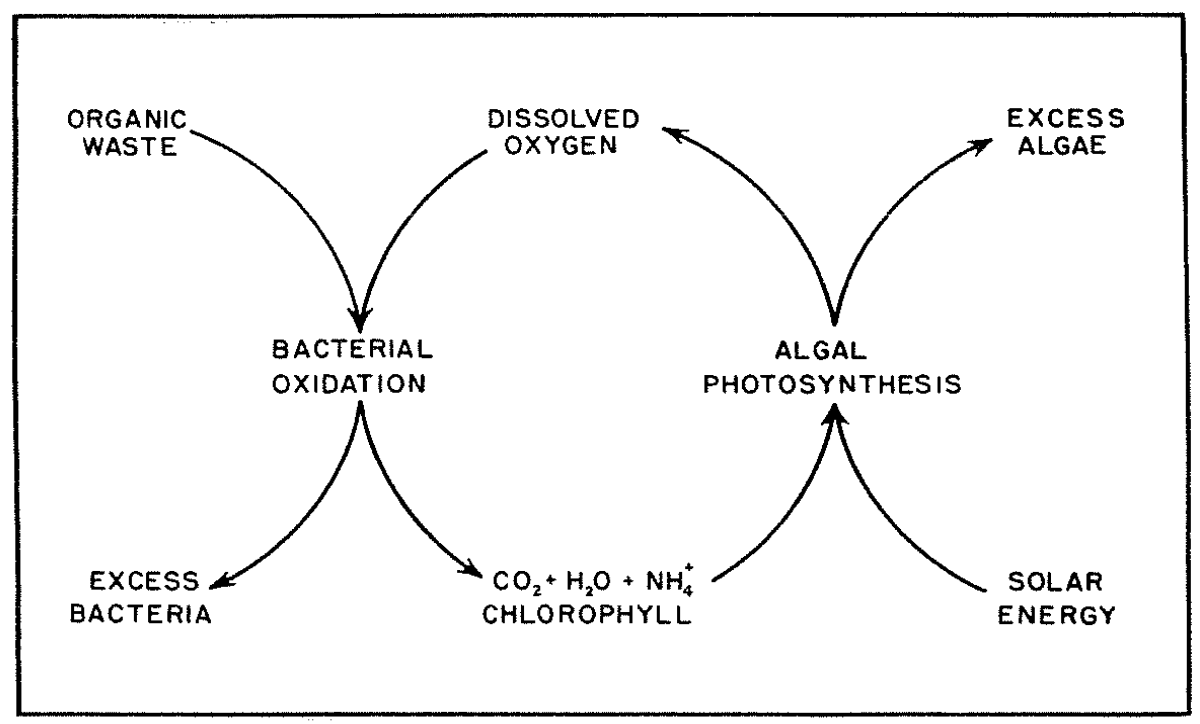

Figure 2.3: Diagram showing the symbiotic relationship between bacteria and algae with the products and constituents of each process (Oswald et al. 1955).

If the rates of algal photosynthesis and bacteria oxidation are in equilibrium, no additional oxygen need be added to the ponds. However, oxygen production can be hindered by many common occurrences such as a cloudy day and excessive zooplankton grazing (Metcalf and Eddy 1991). In order to prevent a slowing of biological activity within the pond, aerators are commonly installed in pond systems to add dissolved oxygen to the wastewater when $\mathrm{O}_{2}$ production by algae is insufficient.

There are many configurations of pond systems, but Oswald describes a system that the WWWTP seems to be modeled after. The pond system is characterized by a primary digestion 
pit followed by an aerobic zone, followed by a secondary solids digestion pit (Oswald et al. 1990). An anaerobic pond will provide some BOD removal and will provide anaerobic digestion of solids. The depth of this pond must be sufficient to allow for the settling and anaerobic digestion of primary wastewater solids. After 20 to 30 days, water exits into a facultative pond. This pond provides some anaerobic digestion in the benthic zone and aerobic respiration as BOD is removed from the water. An aerobic pond receives effluent from the facultative pond to polish the wastewater. In this pond pathogens die and remaining BOD is removed by heterotrophic bacteria. The WWWTP contains all of these zones in its three ponds. Two ponds contain anaerobic and facultative zones where solids digestion occurs and BOD removal is sustained by oxygen-rich water provided by algae and surface aerators. A third pond contains a facultative zone and a maturation or aerated zone where solids settle, and the final BOD present in the wastewater is meant to be consumed. The performance and conditions of these ponds are discussed in later sections.

Sludge accumulation is inevitable in a pond system because some sludge is inert and/or inorganic and thus not susceptible to anaerobic digestion. Over time, this material will decrease the liquid volume of the ponds, decreasing retention time and treatment performance. It is reported that in several pond treatment systems in Mexico, sludge production is evenly distributed in anaerobic ponds, and prevalent at the inlets of aerobic ponds (Nelson et al. 2004). Anaerobic ponds are usually smaller in size and deeper than aerobic ponds, and they bear the bulk of the solids deposits from the waste stream. Anaerobic digestion occurs when solids build up on the bottom and are eliminated as bacteria consume organic matter. (Nelson et al. 2004). In order to promote 
anaerobic conditions to digest the primary sludge settling near the influent pipes, Oswald suggested digestion pits (Oswald 1990), as implemented independently at WWWTP.

Pond configuration must be considered in the design of the treatment ponds for the efficient removal of wastewater contaminants and for the duration of the life of the pond. Successful designs optimize the life of the pond system by reducing the accumulation of sludge and provides the necessary treatment to the water entering the treatment plant (Oswald 1990). 
CHAPTER 3: WOODLANDS WASTEWATER TREATMENT PLANT DESCRIPTION

\subsection{Short History of the Woodlands Wastewater Treatment Plant}

The wastewater treatment plant for the Woodlands community started operation in March 2009. The plant currently treats domestic wastewater from 380 single- and multi- family homes, and a 1500 square foot multiuse center located at the golf course. At build-out, the Woodlands development will consist of 1,320 single-family and multi-family residences, a 500-unit resort hotel, 48-hole championship golf course, 150,000 square feet of retail and up to 650,000 square feet of commercial and office space. The increased loading from the additional development will be accommodated by the current under-utilized capacities of the treatment plant and by eventual treatment plant expansion.

\subsection{Description of Treatment Plant Operation}

Influent from the residential community enters the treatment plant where it is processed by a grinder and screen at the headworks. These devices eliminate debris from the wastewater and reduce biological matter to manageable sizes. Debris that cannot pass through the screen is disposed of into a trash receptacle dumpster (Figure 3.2) and transported to a solid waste landfill. Once the water passes through the screen, it enters the pond system. The system at the Woodlands wastewater treatment facility provides BOD removal, solids elimination, and pathogen destruction for the Woodlands community. 


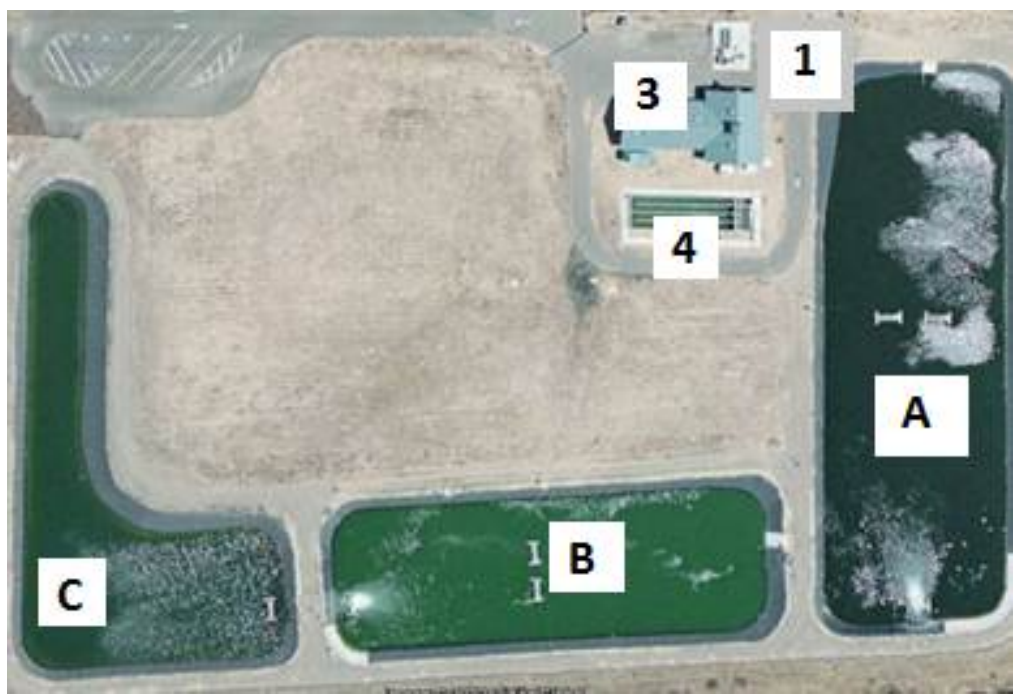

Figure 3.1: Photo of layout of the Woodlands wastewater treatment plant with labeled treatment unit operations (Google Maps, 2012 ).

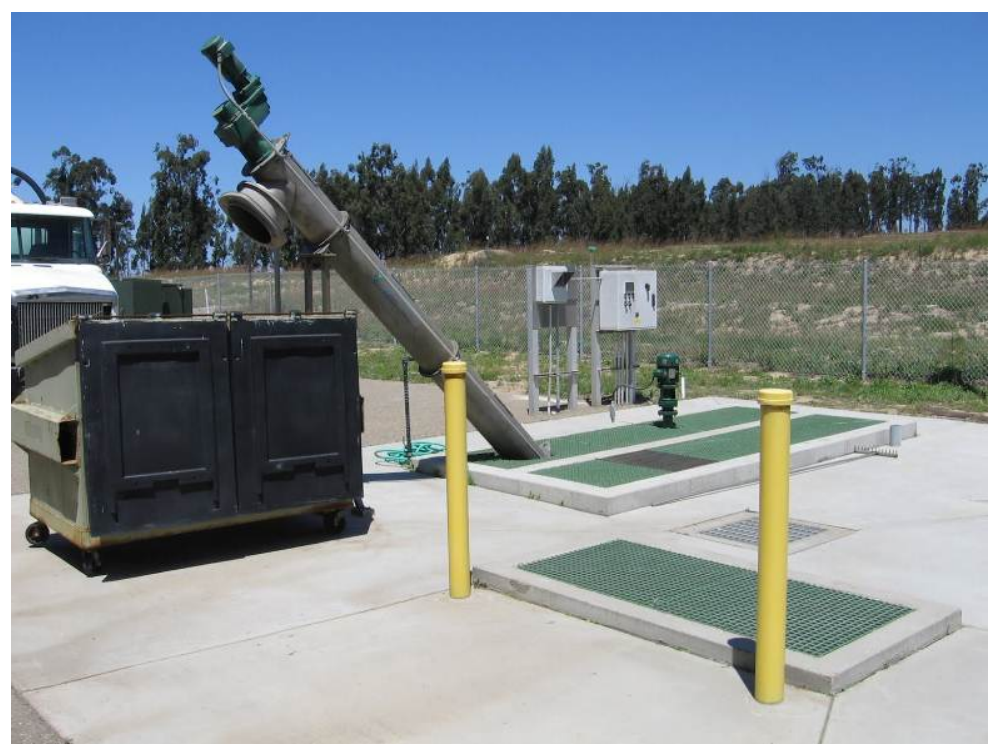

Figure 3.2: Headworks of the WWWTP. Below the grate, a grinder reduces waste to small particles and a screen separates and disposes of debris before it enters the pond system.

Pond $\mathrm{A}$ is a facultative pond with a volume of approximately 3.5 million gallons (MG) of water. Microfilter operation pulls water from the Pond C lowering the water level. 
Dissolved oxygen to support treatment is provided by microalgae suspended in the ponds and is subsidized by multiple aerators that operate independently to maintain the desired oxygen level. A small amount of $\mathrm{O}_{2}$ passively diffuses from the atmosphere into the ponds when surface dissolved oxygen concentrations are less than atmospheric saturation. Effluent from Pond A is discharged to Pond B and then to Pond C, in series. Pond B has a volume of approximately 2.1 MG and is similar in function to Pond A. Pond $\mathrm{C}$ has a volume of $1.71 \mathrm{MG}$ and serves to polish the effluent water before discharging to the microfilter. The maturation zone (Figure 3.5) provides little mixing, additional aeration, and removes all remaining settleable solids.

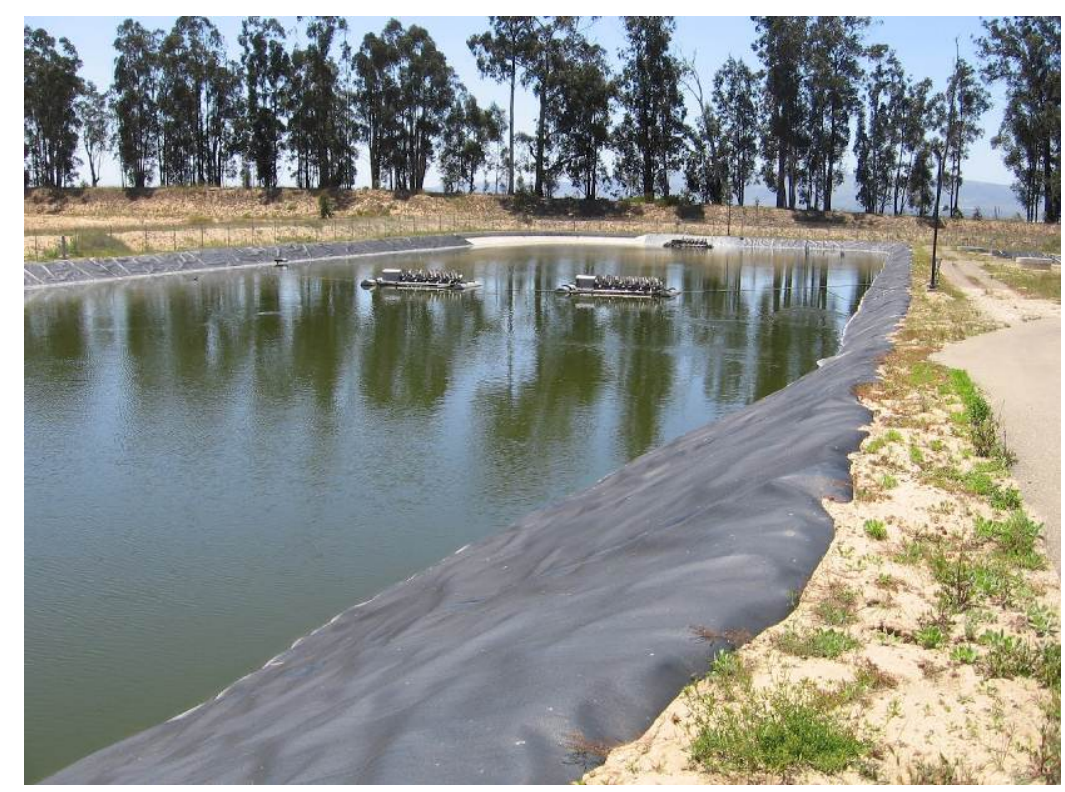

Figure 3.3: Pond A seen from the influent end of pond facing southwest. 


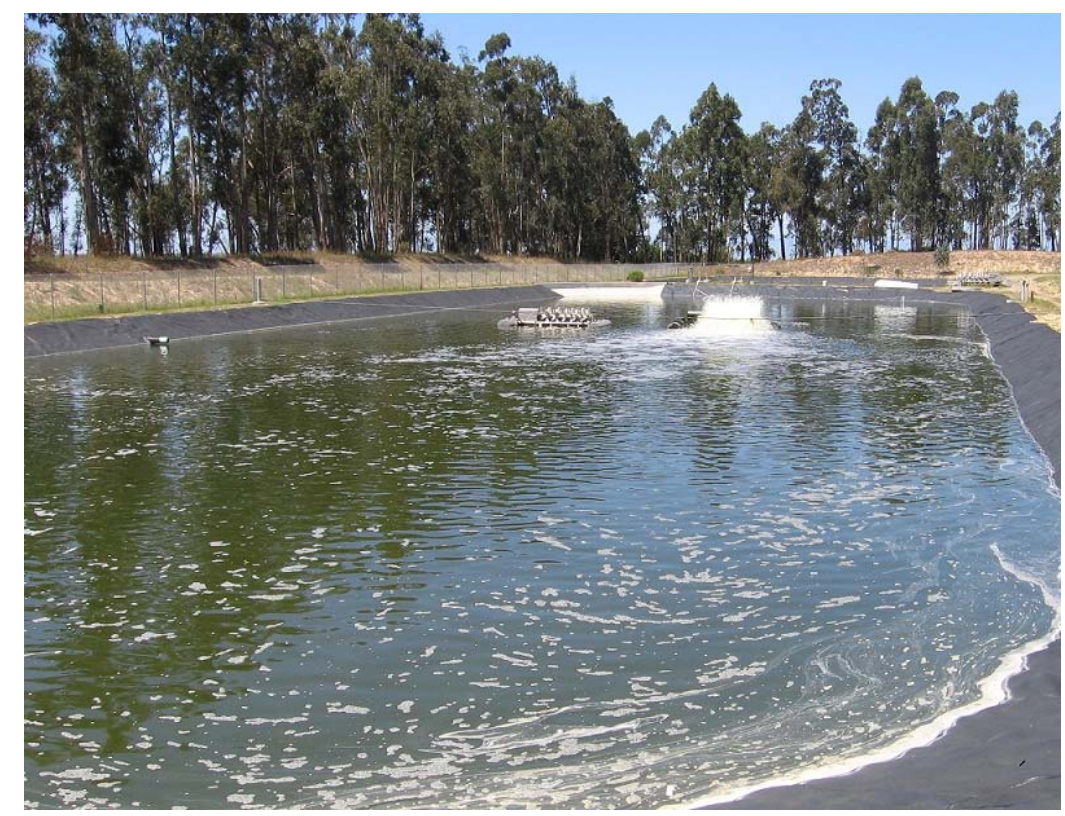

Figure 3.4: Pond B seen from the influent end of pond facing northwest.

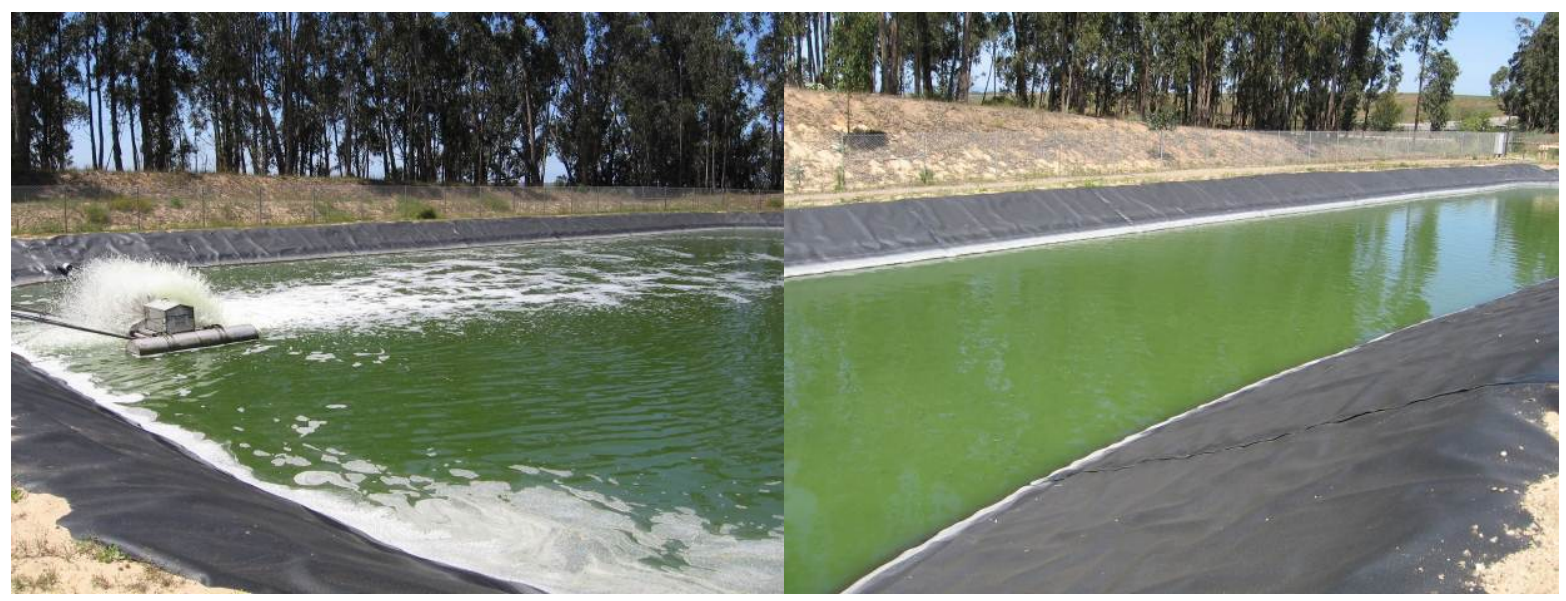

Figure 3.5: Left: Pond $\mathrm{C}$ from influent end. Right: Pond $\mathrm{C}$ looking down at a maturation (unaerated) zone of pond C. Maturation zone in relation to Pond C can be seen in Figure 1.2.

After chlorination, the effluent is pumped to the golf course storage pond for irrigation reuse.

Effluent permit requirements and typical concentrations for BOD and TSS are reported below.

Because this thesis is concerned only with the pond system and the microfilter, the chlorination operations will not be discussed further. 


\subsection{Treatment Plant Expansion Potential}

The current pond system is treating wastewater at approximately one-third capacity and is expected to be able to provide the required treatment for increases in flow expected from the initial stages of the further planned development. More treatment ponds will have to be constructed to treat the expected build-out flow. This expansion was anticipated during the initial planning and design, and thus sufficient land is available for expansion (Figure 3.6).

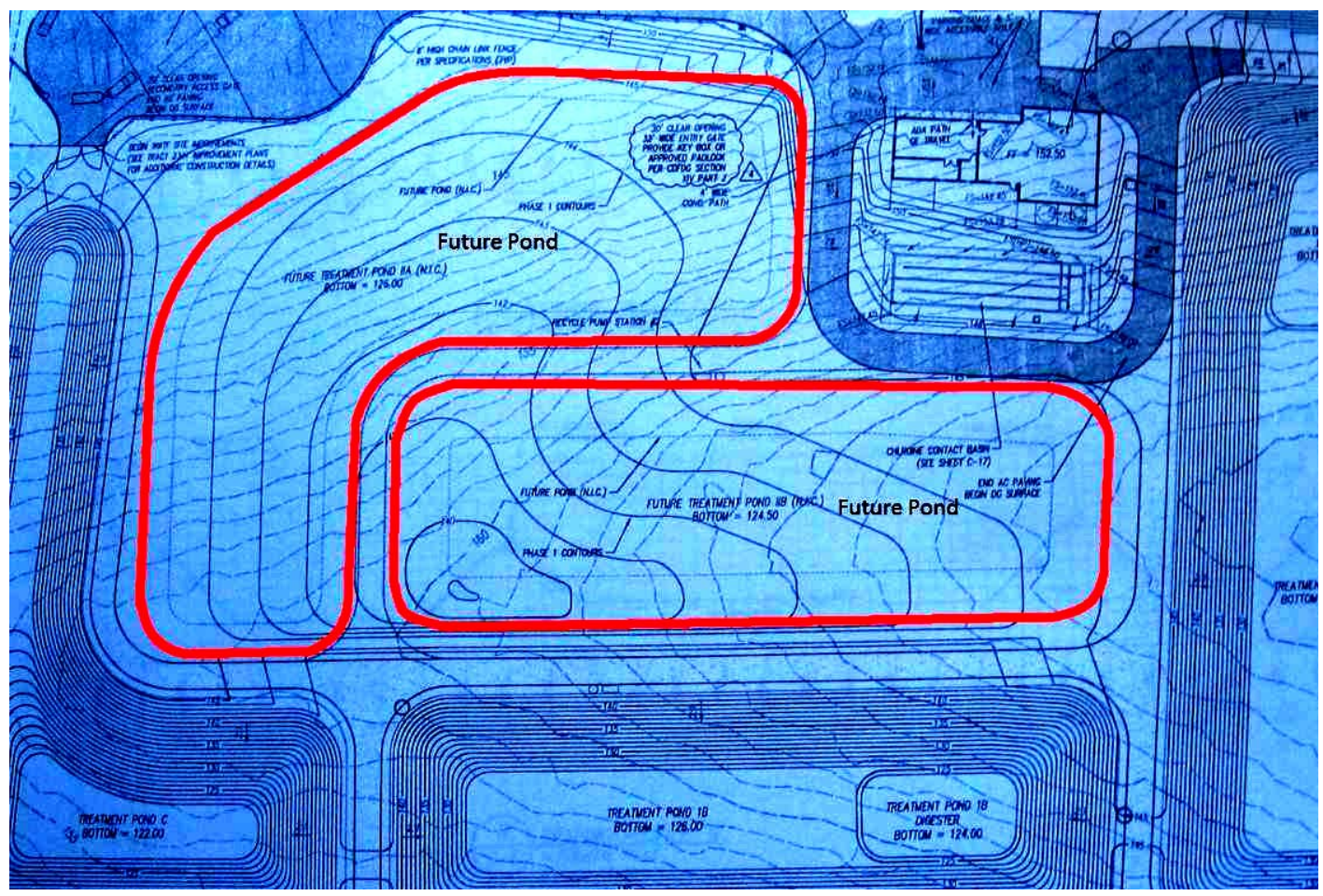

Figure 3.6: Topographical plan of treatment ponds. Highlighted in red are the unused land area available for future conversion to treatment ponds. The existing Ponds A, B, and C border the two future ponds.

\subsection{Pond Dimensions}

The wastewater treatment ponds at the Woodlands treatment facility consist of three ponds with similar dimensions (Table 3.1 Figure 3.7). Although their volumes are similar, the dimensions differ significantly, especially for Pond C. Ponds A and B have digester pits separated from the rest of the pond by a vinyl sheet pile, or equivalent material, wall constructed completely below 
the surface of the pond. All ponds are roughly the same depth except for the maturation zone of Pond C. The so-called maturation zone follows the bulk of Pond C and polishes the wastewater. Any settleable solids still preset, will settle here, decreasing the load to the microfilter.

Table 3.1: Full volumes and approximate dimensions of the ponds. The water surface width and length are given. Digester pits are two feet deeper than recorded depth. The treatment portion of Pond $\mathrm{C}$ and the maturation portion of Pond $\mathrm{C}$ have a combined volume of 1.75 MG. Volumes were given in the plant specifications.

\begin{tabular}{lcccc}
\hline \multicolumn{1}{c}{ Pond } & Width (ft) & Length (ft) & Depth (ft) & Volume (MG) \\
\hline A & 130 & 380 & 15 & 3.5 \\
B & 100 & 300 & 14.5 & 2.1 \\
C (total) & 100 & 180 & 16.5 & 1.25 \\
C (maturation zone) & 50 & 250 & 6 & .5 \\
Total & & & & 7.35 \\
\hline
\end{tabular}




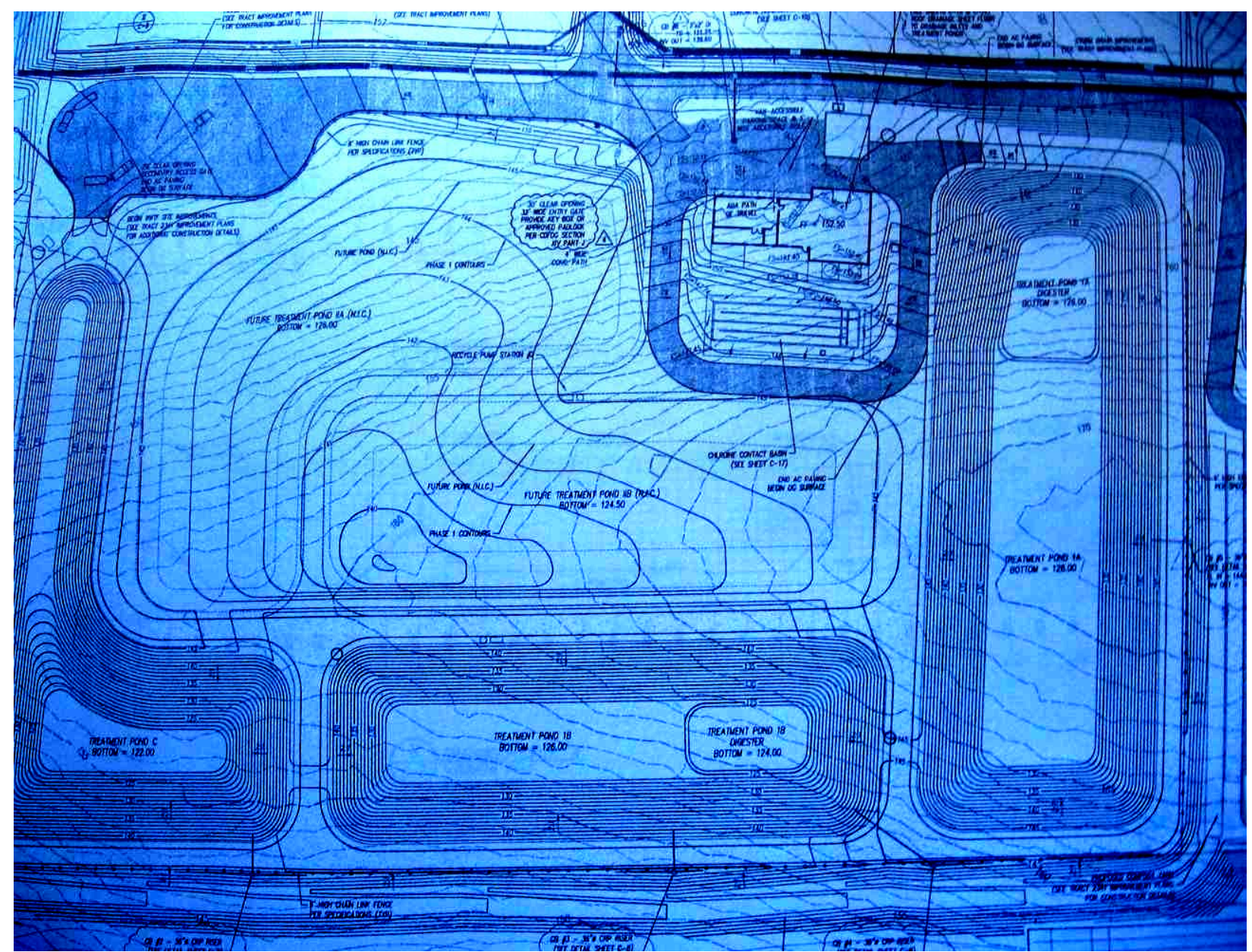

Figure 3.7: Topographical plan of the three treatment ponds. Proposed ponds can be seen in the center of the current ponds and treatment plant facility.

Figure 3.8 shows the plan view of each pond showing the digester location in Ponds A and B.

Digesters are two feet deeper than the main pond. Individual photographs of the plans for Ponds $\mathrm{A}, \mathrm{B}$, and $\mathrm{C}$ can be found in the appendix.

\subsection{Flow Characteristics}

Influent wastewater flow is monitored at the headworks using an influent flume and transducer.

Each week, when the operators perform their weekly quality tests, they record the weekly volume of influent. During this study the influent averaged about 25,000 gallons per day (GPD). This flow can be evaluated considering that the development has about 380 homes currently. At 
2 persons per home, 760 persons is a preliminary estimate of the population. However, at a typical wastewater production of $70 \mathrm{gal} /$ person-d, the flow would be about 53,200 gal per day. The lower actual flow leads one to conclude that about half of the residents of the development do not live in the homes year around. They are likely to be second homes or vacation homes. With a total pond volume of 7.35 MG, the residence time of the water being processed by the treatment plant is a long 294 days (Table 3.2), which is much longer than many California treatment ponds designs.

Table 3.2: Volume in millions of gallons (MG) and retention time for each pond and the total pond system, with a 25,000 gallon per day average flow.

\begin{tabular}{lcc}
\hline Pond & Volume (MG) & Retention Time (days) \\
\hline A & 3.5 & 140 \\
B & 2.1 & 84 \\
C & 1.75 & 70 \\
Total & 7.35 & $\mathbf{2 9 4}$ \\
\hline
\end{tabular}

\subsection{Load Characteristics}

Weekly total $\mathrm{BOD}_{5}$ and TSS influent values are determined by a commercial laboratory and submitted to the RWQCB by the operators. Since commissioning, average influent concentrations were found to be 400 and $385 \mathrm{mg} / \mathrm{L}$ of $\mathrm{BOD}_{5}$ and TSS, respectively. $\mathrm{BOD}_{5}$ values range from $100-1,000 \mathrm{mg} / \mathrm{L}$ with a few outliers above $1,000 \mathrm{mg} / \mathrm{L}$. TSS concentrations range between 50 and 1,000 $\mathrm{mg} / \mathrm{L}$. Using average BOD and TSS values, an influent load is calculated to be $38 \mathrm{~kg} \mathrm{BOD}_{5} /$ day and $36 \mathrm{~kg}$ TSS/day. $\mathrm{BOD}_{5}$ influent loading translates to 36.8 $\mathrm{kg} \mathrm{BOD}_{5} /$ hect-day and $33.1 \mathrm{lbs} \mathrm{BOD}_{5} /$ acre-day. Typical influent design loading recommendations for coastal California climate are slightly greater at $40 \mathrm{lbs} \mathrm{BOD}_{5} / \mathrm{acre}$-day, but 
aeration makes this a flexible criterion. Increased population in the Woodlands community will increase the load to the ponds.

\subsection{Maintenance}

Maintaining the pond system is limited to debris removal and mechanical maintenance on aerators and pumps. Inspection of the pond system at the Woodlands plant is carried out by the operators daily.

1. Water levels are managed by observation. Treatment plant operators manually engage the microfilter to decrease the level of treatment Pond C. The microfilter pulls water from Pond $\mathrm{C}$ for filtration, lowering the water level of the pond system. Pond A and B water levels are regulated automatically with overflow weirs and a recirculation pump, and are consistently the same volume.

2. Debris is removed from the ponds each day, if present.

3. Weekly water quality monitoring is conducted as follows:
A. Influent and post chlorination effluent BOD/TSS sampling
B. Chlorine level readings with adjustment, if necessary, to achieve target residual
C. $\mathrm{pH}$ reading of effluent

Dissolved oxygen levels are maintained automatically. DO probes are positioned throughout the pond system (Figure 3.8) and trigger aerator operation when levels drop below $2 \mathrm{mg} / \mathrm{L}$ DO (Table 3.3). 


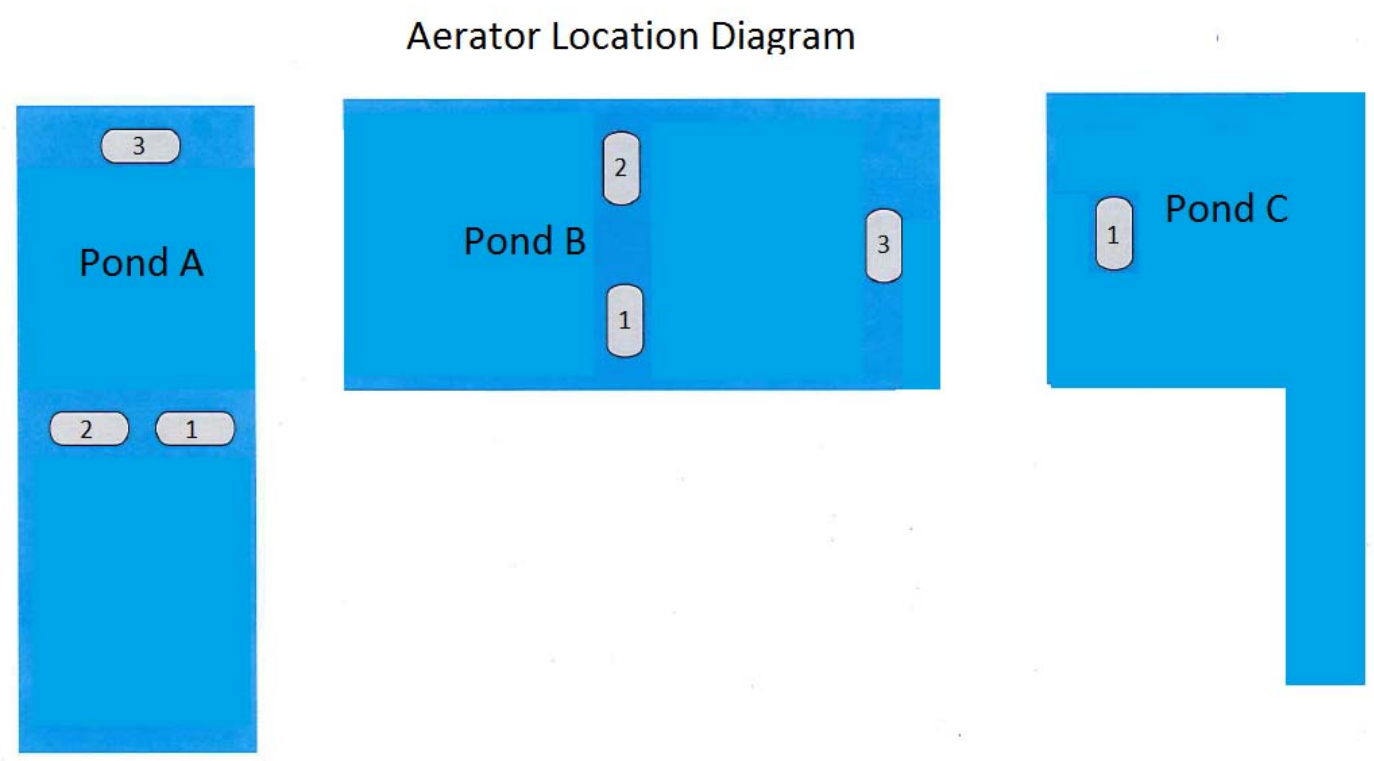

Figure 3.8: Schematic of the treatment ponds and the Horizontal Rotor Aerators in Ponds A, B, and $\mathrm{C}$.

Table 3.3: Dissolved oxygen set-points for automatic aerator operation in each pond at the WWWTP.

\begin{tabular}{ccc}
\hline & \multicolumn{2}{c}{ Dissolved Oxygen Trigger Levels } \\
\hline Aerator & Turn On mg/L & Turn Off mg/L \\
\hline $\mathbf{1}$ & 2.0 & 2.5 \\
$\mathbf{2}$ & 2.0 & 2.3 \\
$\mathbf{3}$ & 2.0 & 2.2 \\
\hline
\end{tabular}

In three years of operation, the pond system and the operators have experienced only routine maintenance requirements and have not encountered any large scale or emergency related maintenance issues. 


\subsection{Regional Water Quality Control Board Regulations}

The Central Coast Regional Water Quality Control Board (RWQCB) is the main regulatory agency for the WWWTP, including regulation of wastewater reuse for irrigation of the Monarch Dunes golf course. The RWQCB waste discharge requirements are outlined in Table 3.4, which is copied from the WWWTP permit from the RWQCB. Nutrients discharged by this plant are not regulated by the RWQCB, probably because most nutrients are assumed to be taken up by the golf course and prevented from reaching the water table and groundwater supply.

Table 3.4: The effluent water quality requirements of the Woodlands treatment facility set by the RWQCB.

\section{Effluent Limits}

\begin{tabular}{l|r|r|r}
\hline Parameter & Units & Mean & \multicolumn{1}{l}{ Max } \\
\hline BOD & $\mathrm{mq} / \mathrm{l}$ & 10 & 30 \\
Suspended Solids & $\mathrm{mg} / \mathrm{l}$ & 10 & 30 \\
\hline Settleable Solids & $\mathrm{ml} / \mathrm{l}$ & 0.1 & 0.3 \\
\hline Turbidity & $\mathrm{NTU}$ & $2^{*}$ & $5^{\star \star}$ \\
\hline TDS & $\mathrm{mg} / \mathrm{l}$ & & 710 \\
\hline pH & Within range of 6.5 to 8.4 & \\
Parameter & Units & Mean & Max
\end{tabular}




\section{CHAPTER 4: MICROFILTER CHARACTERISTICS}

\subsection{Microfilter System}

The WWWTP uses microfiltration to remove solids and pathogens from the waste stream.

Solids include remaining particulate organic matter not eliminated by the ponds and suspended microalgae. The microfilter is a Pall Aria AP-4, which is a hollow fiber tube microfiltration system. The product cut sheet and specifications of this filter can be found in the appendix and are summarized here.

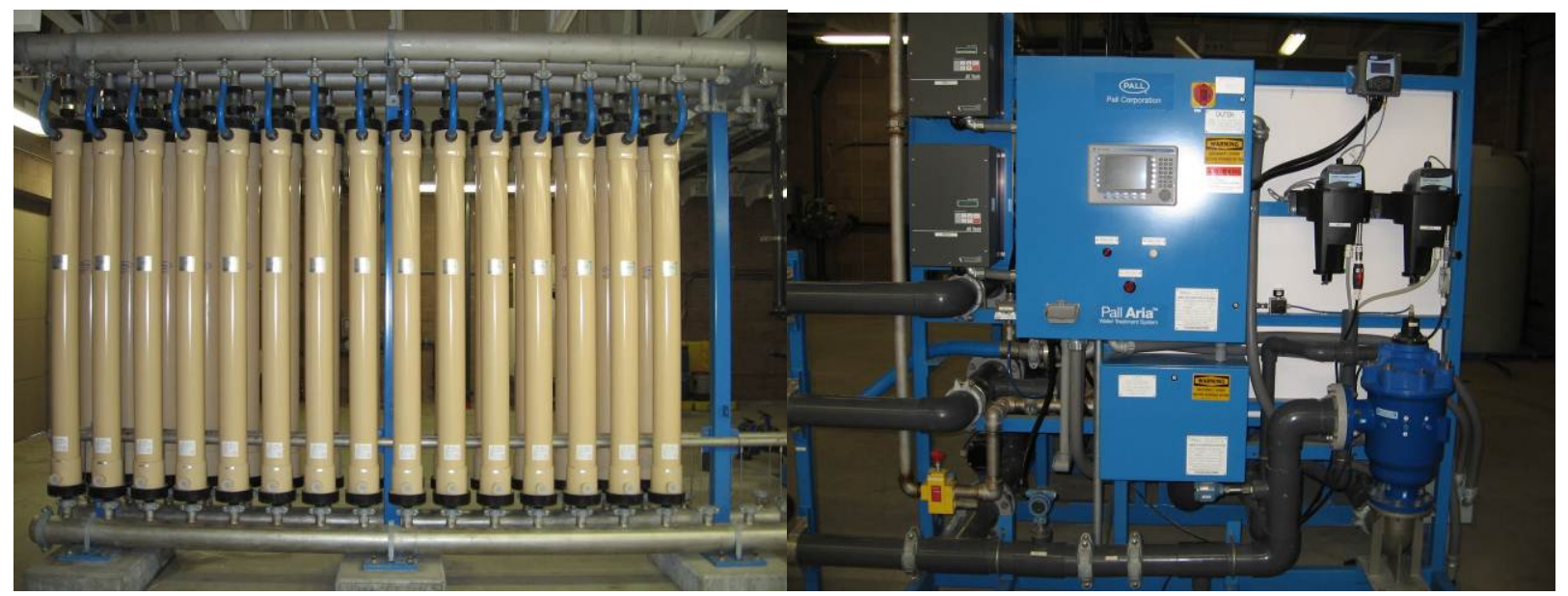

Figure 4.1: Right: Microfilter skid containing 30 microfilter elements. Each filter element is filled with hollow fiber tube filters. Left: Pall Brand Aria AS series control module. 

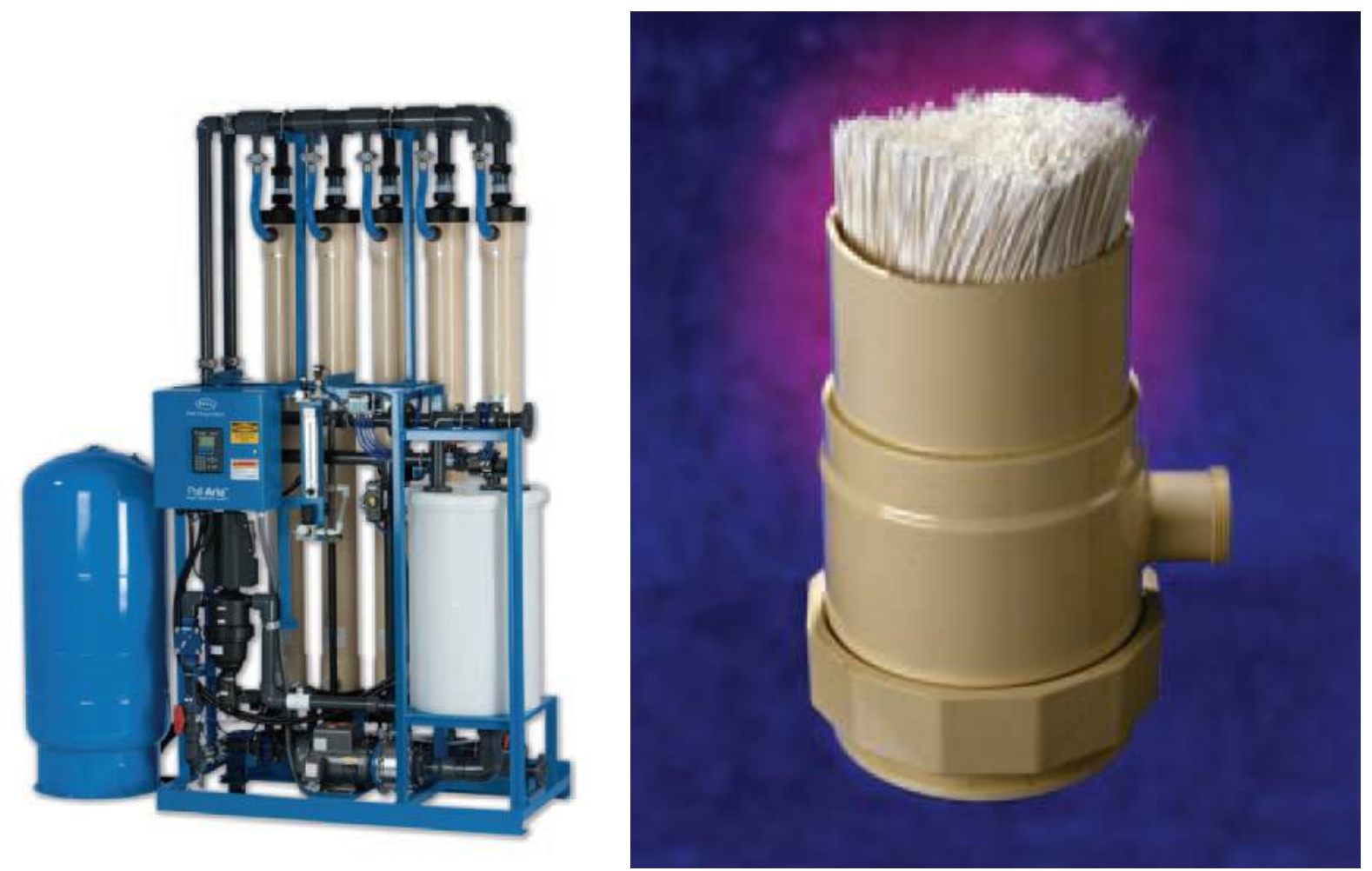

Figure 4.2: The Pall Aria AP-4 series used at the Woodlands wastewater treatment facility is similar to the one shown above. Left: A system with five modules. Right: cross section of single module with hollow fibers (Pall literature).

Prior to entering the modules, Pond C effluent passes through a 200-micron strainer. Elements house 0.1-micron polyvinylidene fluoride (PVDF) regenereable hollow fiber tubes. Each element is about one foot in diameter and $3.35 \mathrm{~m}(11 \mathrm{ft})$ tall, providing a nominal filter surface area of up to $50 \mathrm{~m}^{2}\left(538 \mathrm{ft}^{2}\right)$. The Woodlands treatment plant is currently using 30 elements for a total of $1500 \mathrm{~m}^{2}\left(16,140 \mathrm{ft}^{2}\right)$ of filter surface area. According to Pall, the microfilter system is capable or 6-log removal, or 99.9999\%, of Giardia, Cryptosporidium, total coliform, and E. coli (Figure A.6).

The Woodlands microfiltration system operates at an average flow of 100 gallon per minute (GPM). The hollow fiber elements are operated in the outside-in configuration, meaning that the 
water flows into the spaces surrounding the hollow tubes and is forced in through the membranous walls of the tube, filtering out anything larger than $0.1 \mu \mathrm{m}$ in size (Figure A.6).

\subsection{Expansion Plans}

When the Woodlands housing community expands and the load to the treatment plant increases, the microfiltration system may have to be expanded to maintain a sustainable flux. The building housing the current system is capable of housing extra microfiltration units needed for build-out of the Woodlands community. The retrofit would be accomplished by adding more microfiltration systems to the current plant. Adding modules to the current system will require more flow and pressure head than the current system is capable of providing, so additional modules will be installed when the need for larger filtering capacity is required.

\subsection{Microfilter Maintenance}

Microfilter maintenance is performed regularly and consists of periodic backwashes and chemical cleanings. Backwashes are induced by the computer system every 20 minutes or every 7,000 gallons of filtrate produced. The backwash procedure is summarized below.

1. Air Scrub: Air is pumped into the modules at a rate of 240 GPM for 60 seconds to scour the sides of the module of cake build-up.

2. Reverse Flux: Filtrate is pumped from the effluent tank back through the filter for 5 minutes, pushing out any particles caught in the pores of the microfilter.

3. Flush: Water is cycled into the filter for 30 seconds and discharged. This step is conducted under pressure too low for the feed water to enter the pores. The purpose 
of the flush is to clear away any air bubbles or particles still present in the module after the air scrub and simultaneous reverse flux.

Chemical cleanings are performed manually and as needed. Standard operation is that chemical cleanings be performed every three to six months depending on the amount of microfilter operation. Since commencement, chemical cleanings have been performed only on an as-needed basis when algae growth is high during the summer months. Three chemical cleanings per year have been typical for the WWWTP. Chemical cleaning operations are summarized below and in Table 4.1.

1. The Pall Aria AP system empties the hollow fiber modules of the feed stream.

2. A caustic soda and chlorine mixture is cycled through the microfilter modules for 60 $\min$.

a. Modules are rinsed with filtrate for 5 min to wash away caustic soda and chlorine from modules.

3. Acidic solution (citric acid) is cycled through the microfilter modules for $60 \mathrm{~min}$.

a. Final rinse with filtrate is conducted for 5 minutes to wash away citric acid from modules.

Table 4.1: Caustic and acidic additions to rinse water during chemical cleaning.

\begin{tabular}{cccccc}
\hline & Caustic Soda & Chlorine & Citric Acid & Water & Final Rinse \\
\hline Gallons Added & 7.6 & 1.2 & 15 & 475 & \\
Concentration & $1.6 \%$ & $0.025 \%$ & $3.1 \%$ & & \\
Time Cycled (min) & 60 & 60 & 60 & & 5 \\
\hline
\end{tabular}


During normal operating conditions, pressure is measured on either side of the filter to track the pressure required to push the water through the membrane. The microfilter operates at a pressure difference of 2.5 - 3 psi for the majority of the year. 


\section{CHAPTER 5: METHODS}

\subsection{Sampling}

Wastewater samples were collected at the WWWTP for analysis, approximately once per week from September 2, 2011 to March 7, 2012. Samples were taken at the following locations.

1. Headworks (after screening)

2. Pond A effluent weir splitter box

3. Pond B effluent weir splitter box

4. Pond C effluent holding tank (storage before micro-filtration)

5. Microfilter effluent from sampling spigot

6. Microfilter backwash

Samples were taken from water flowing over weirs to be representative of the bulk pond water, and free of concentrated debris (scum for example). Samples were collected using a pole sampler (Figure 5.1). 


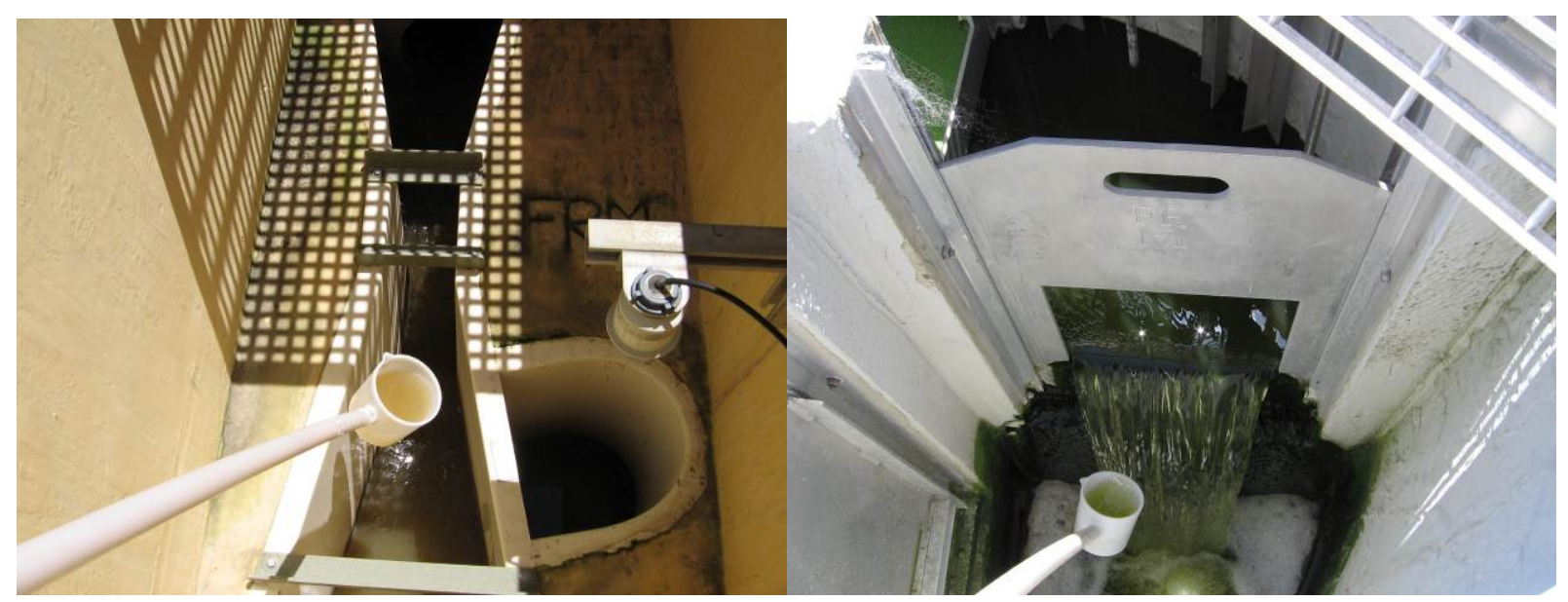

(a)

(b)

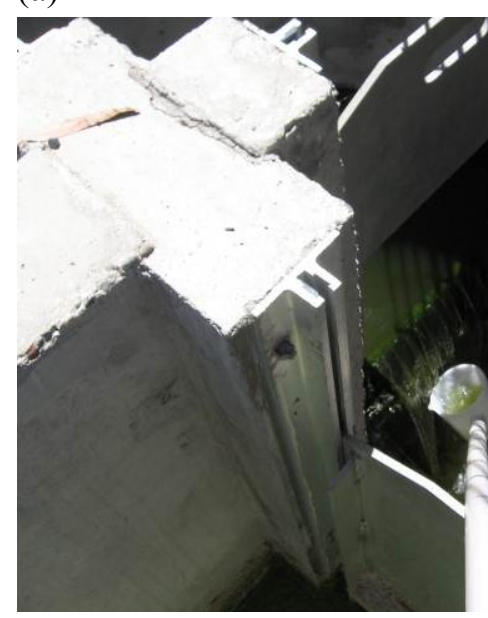

(c)

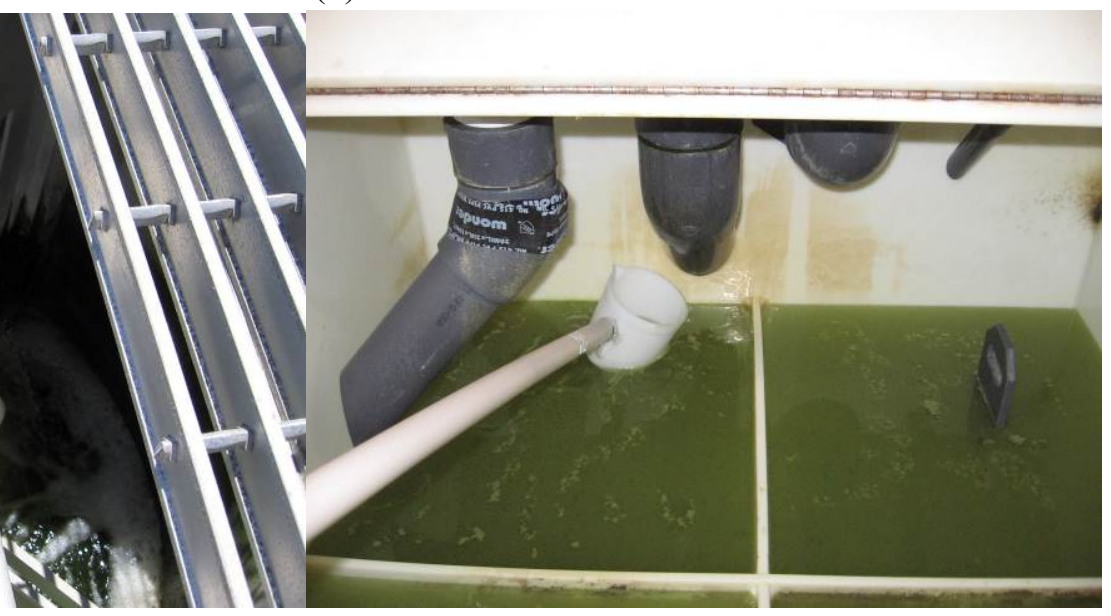

(d)

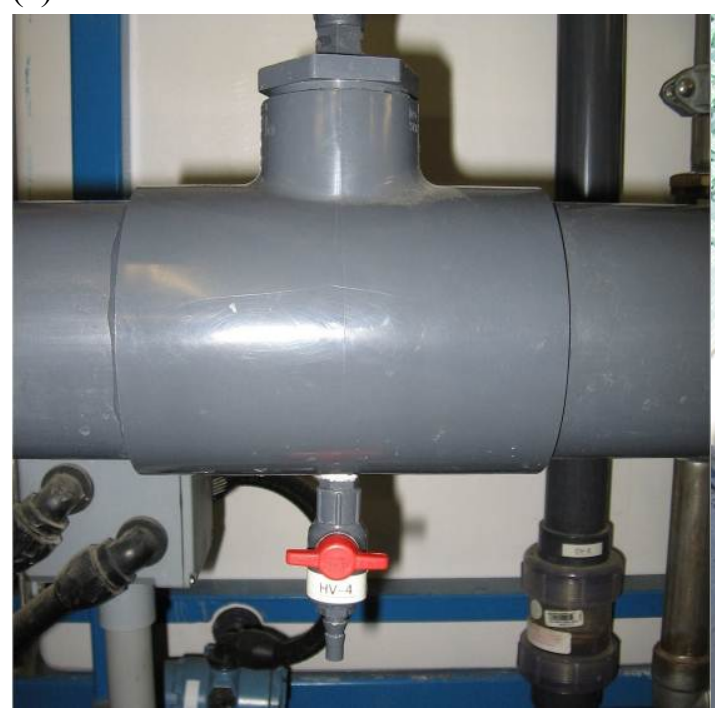

(e)

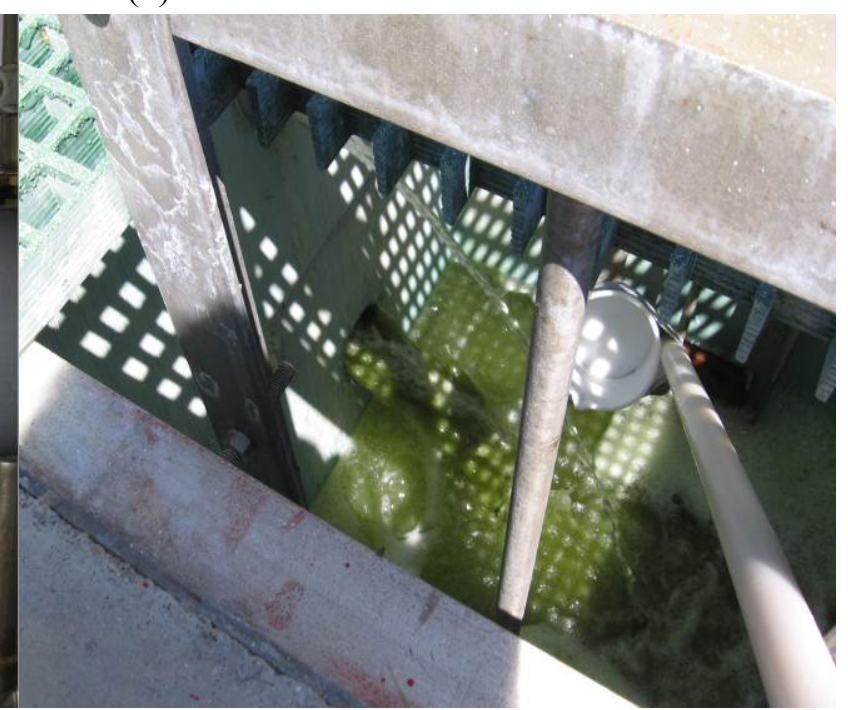

(f)

Figure 5.1: Photographs of locations of sample collection. (a) Influent flume. (b) Pond A effluent weir. (c) Pond B effluent weir. (d) Pond 3 collection box. (e) Microfilter effluent spigot. (f) Microfilter backwash. 
Samples were stored in 500-mL HDPE sample bottles. Approximately $1000 \mathrm{~mL}$ was collected from each location, each week for analysis. Samples were transported immediately back to Cal Poly for analysis. Samples were stored in an ice chest for transportation to reduce any effects temperature and light may have on the samples, and stored at room temperature in the lab until the tests were performed. Lab procedures were concluded within 3 hours of collection. The following lab tests were conducted in accordance with standard methods.

1. 5-day carbonaceous soluble biochemical oxygen demand $\left(\operatorname{csBOD}_{5}\right)$

a. Standard Methods 2004-2006 (5210)

b. Splits and standards were performed

2. Total suspended solids/volatile suspended solids (TSS/VSS)

a. Standard Methods 2004-2006 (2540)

b. Splits and standards were performed

3. Total alkalinity (ALK)

a. Standard Methods 2004-2006 (2320)

b. Splits were performed

4. Total ammonia nitrogen $\left(\mathrm{NH}_{3}{ }^{+}, \mathrm{NH}_{4}{ }^{+}\right.$or $\left.\mathrm{NHx}\right)$

a. Standard Methods 2004-2006 (4500)

b. Matrix spike was performed

Lab tests were conducted by undergraduate students in the Department of Civil and Environmental Engineering under the supervision of the author, with assistance from Prof. Lundquist. Data analysis was conducted by the author and reported in this thesis. Data obtained from the WWWTP for the past three years by the plant operators were used to analyze trends of pond quality. 


\section{CHAPTER 6: ANALYSIS OF HISTORICAL DATA}

Woodlands Wastewater Treatment Plant was commissioned March 2009. Plant operators submit monthly reports to comply with RWQCB permit requirements. The water quality limits prescribed in the RWQCB permit were discussed in Section 3.9 and, in this section, the performance of the treatment plant will be described.

For the RWQCB reports, routine samples are collected at two points: influent samples are collected after the grinder and screen (i.e., before discharge into Pond A). Effluent samples are collected at the chlorine contact chamber exit for reuse on the golf course.

\subsection{Biochemical Oxygen Demand}

Removal of 5-day total biochemical oxygen demand $\left(\mathrm{tBOD}_{5}\right)$, a parameter used to judge treatment performance was tested. The plant consistently removed tBOD to below the limits required despite a wide range of influent tBOD concentrations (Figures 6.1 and 6.2). RWQCB effluent discharge limits require that effluent recycled for irrigation has a monthly average of 10 $\mathrm{mg} / \mathrm{L}$ and no single measurement above $30 \mathrm{mg} / \mathrm{L}$. 


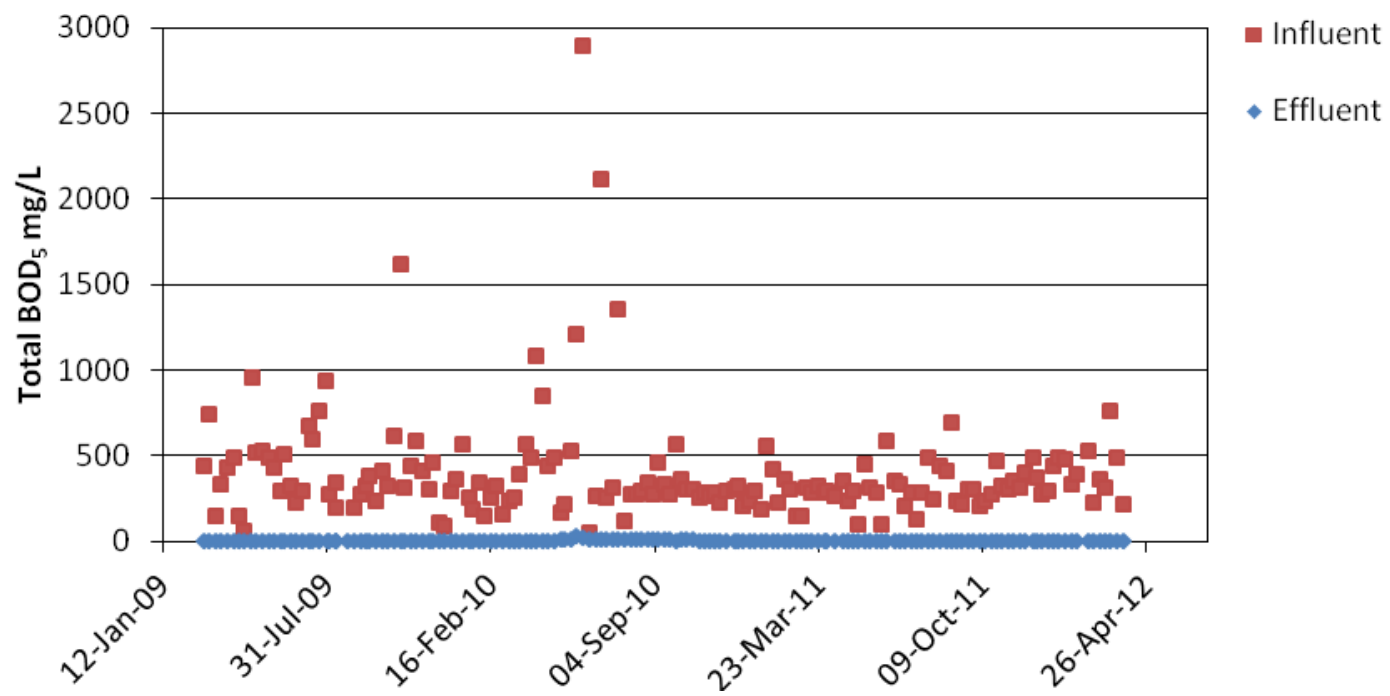

Figure 6.1a: Total $\mathrm{BOD}_{5}$ in the influent and effluent of the WWWTP from March 2009 through March 2012, as reported in monthly reports to the RWQCB.

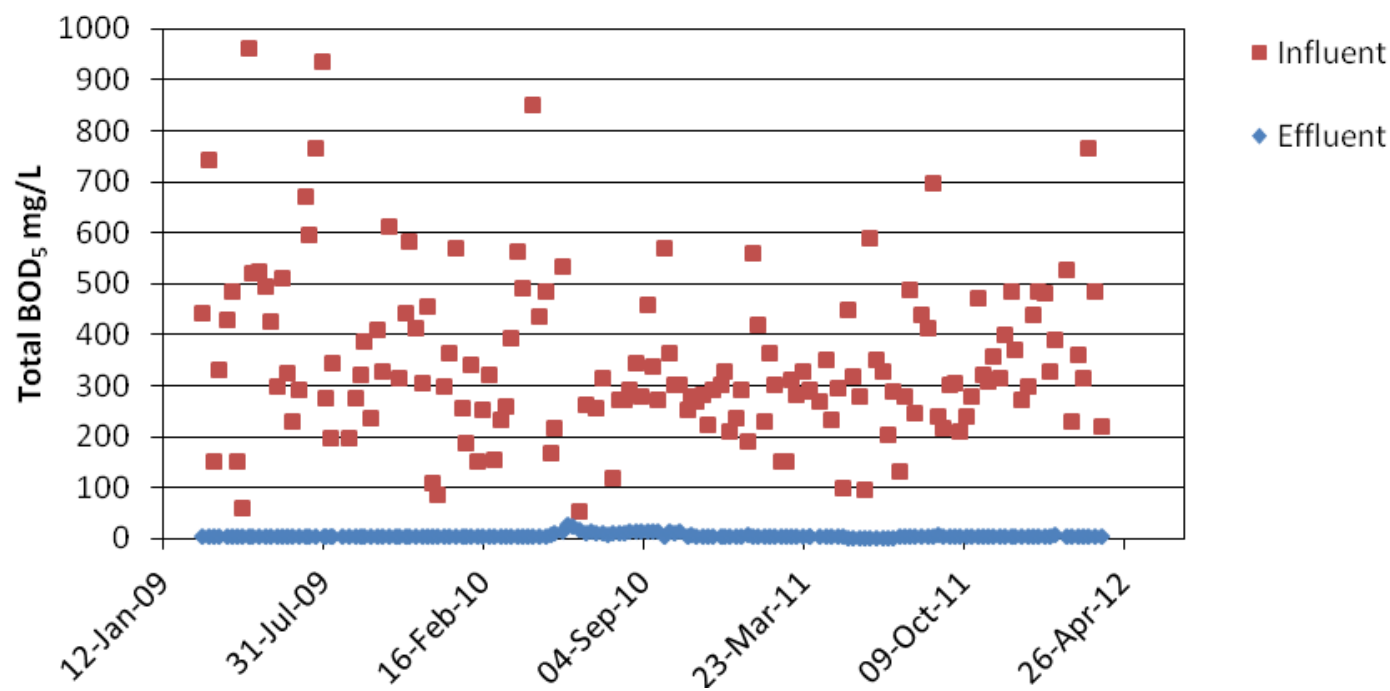

Figure 6.1b: Total $\mathrm{BOD}_{5}$ in the influent and effluent of the WWWTP from March 2009 through March 2012, as reported in monthly reports to the RWQCB. Y-axis scale has been changed to omit the highest measurements in order to show more detail in the typical influent range. 


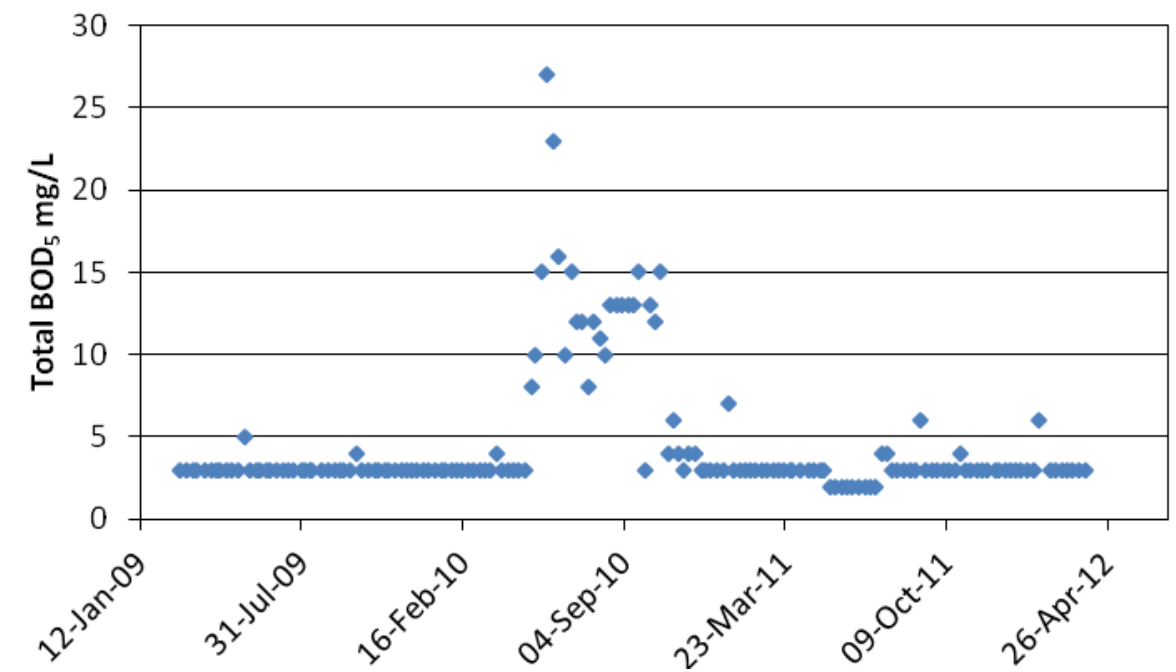

Figure 6.1c: Total $\mathrm{BOD}_{5}$ concentration of plant effluent from January 2009 to March 2012. The increase in tBOD effluent concentration was reported by the operators to be the result of acetic acid addition to the microfilter effluent in the chlorine contact basin for $\mathrm{pH}$ control.

Most influent $\mathrm{BOD}_{5}$ concentrations were less than $1,000 \mathrm{mg} / \mathrm{L}$, with an average of $400 \mathrm{mg} / \mathrm{L}$. Variability of influent concentration was considerable, with an average (arithmetic mean) tBOD concentration of $400 \mathrm{mg} / \mathrm{L}$, a standard deviation of $330 \mathrm{mg} / \mathrm{L}$, and a median concentration of 315 $\mathrm{mg} / \mathrm{L}$. Seasonal patterns in tBOD concentration are not apparent. From approximately February 2010 to September 2010, some $\mathrm{BOD}_{5}$ readings were far greater than the average. No explanations for this increase are given in the monthly reports. Because only tBOD was measured, it was not possible from the permit reporting to determine the effects of season, for example, on soluble BOD removal. Effluent tBOD was consistently below $5 \mathrm{mg} / \mathrm{L}$. Many exceptions to this pattern occur between May and October 2010 (Figure 6.1b). Many tBOD concentrations in this period are above $10 \mathrm{mg} / \mathrm{L}$, which is above the mean effluent limit. According to the permit report notes provided to the RWQCB, this increase in tBOD is the result of acetic acid added to water before chlorination for $\mathrm{pH}$ control. Due to the citric acid interference, the effluent tBOD data between May and October 2010 will be omitted from the 
subsequent analysis in this thesis. Excluding the months when citric acid was added, average effluent tBOD effluent was $3 \mathrm{mg} / \mathrm{L}$ with a standard deviation of $0.8 \mathrm{mg} / \mathrm{L}$.

The high performance of the plant can be attributed to the consistent moderate climate, long pond hydraulic residence times, low influent tBOD loading, and microfiltration.

\subsection{Total Suspended Solids}

Overall TSS concentrations in the WWWTP were lowered from high levels typical of municipal waste to low levels as required by the RWQCB. In treatment ponds, total suspended solids (TSS) of wastewater origin are removed via settling, but algal TSS are created. Final removal of TSS was accomplished at WWWTP by the microfilters.

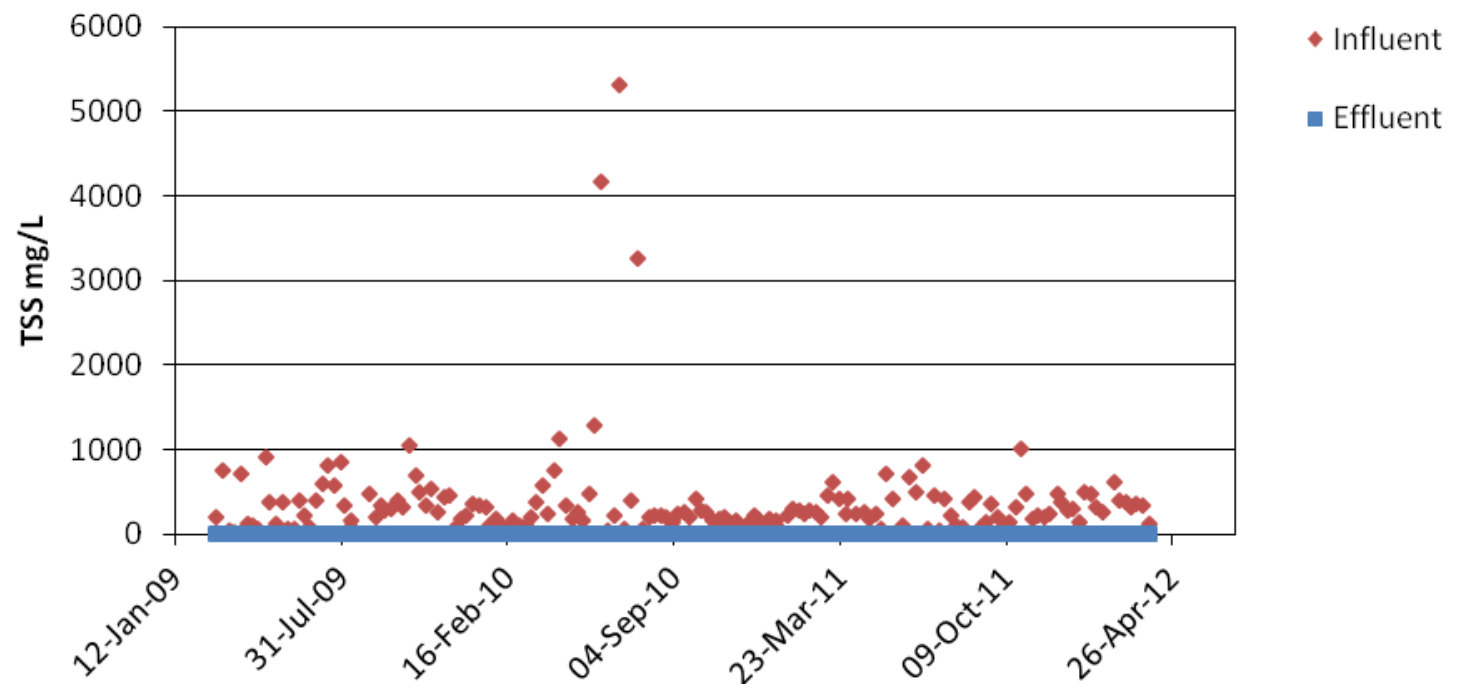

Figure 6.2a: TSS influent and effluent of the WWWTP from March 2009 through March 2012, as reported in monthly reports to the RWQCB. 


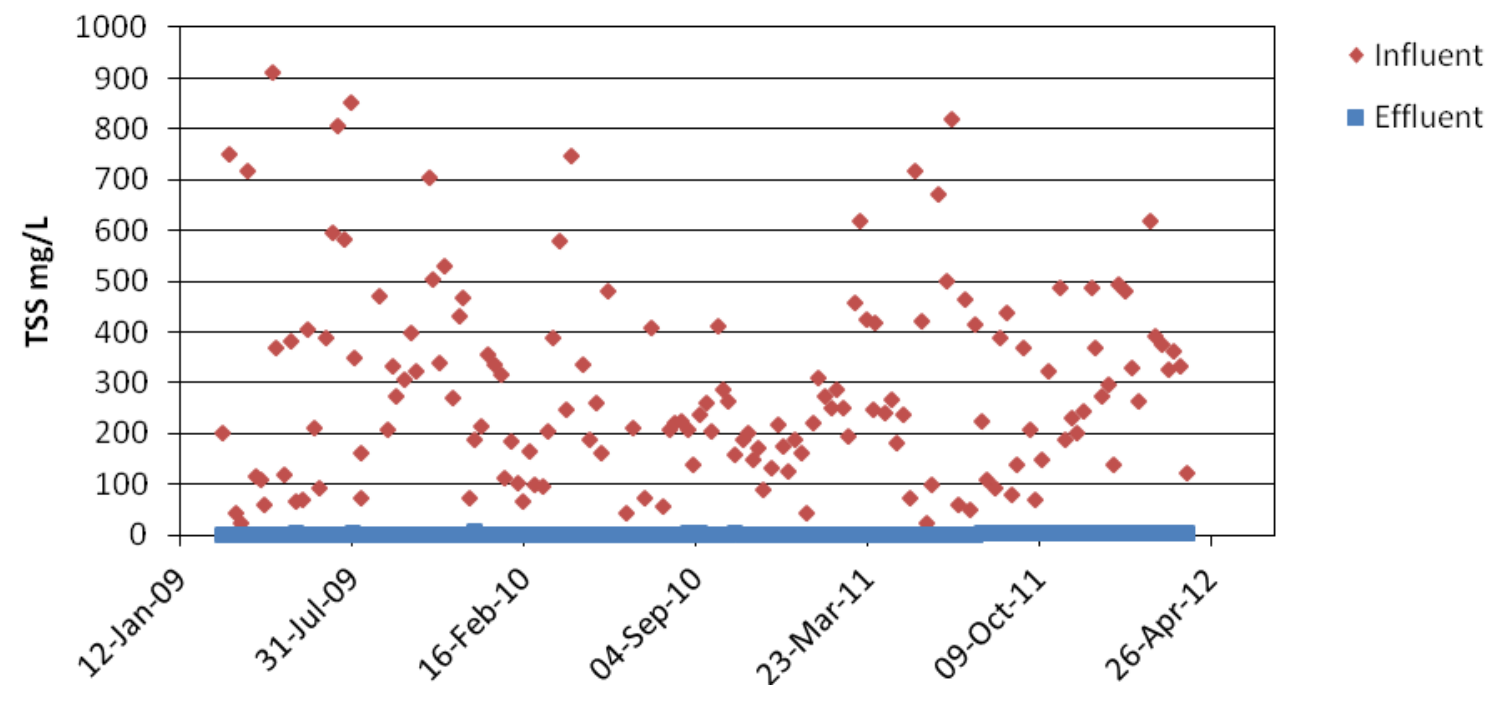

Figure 6.2b: TSS influent and effluent of the WWWTP from March 2009 through March 2012, as reported in monthly reports to the RWQCB.

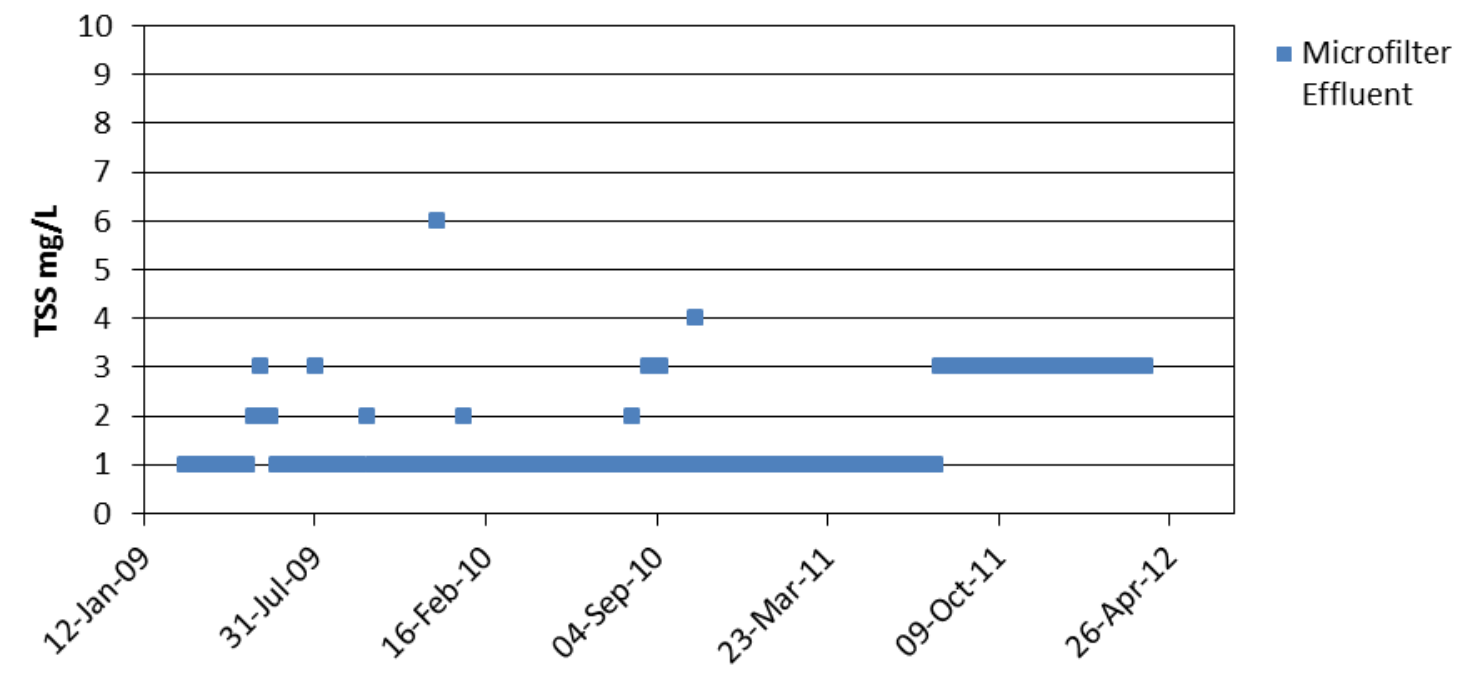

Figure 6.2c: TSS effluent of the WWWTP from March 2009 through March 2012, as reported in monthly reports to the RWQCB.

The periods of elevated TSS and tBOD concentrations in the effluent generally coincide (Figure 6.2c). The influent concentration spikes had no apparent effect on effluent quality. Like influent tBOD concentrations, TSS concentrations do not follow any seasonal patterns. The majority of influent concentrations fall between 50 and $500 \mathrm{mg} / \mathrm{L}$. The mean TSS influent 
concentration was $385 \mathrm{mg} / \mathrm{L}$, the standard deviation is $593 \mathrm{mg} / \mathrm{L}$, and the median is $256 \mathrm{mg} / \mathrm{L}$. TSS levels at the WWWTP are typical of medium to high strength municipal wastewater (Metcalf et al. 1991). Even when influent concentrations were uncharacteristically high, the microfilters were capable of removing TSS to an average of $1.6 \mathrm{mg} / \mathrm{L}$ and a standard deviation of $1 \mathrm{mg} / \mathrm{L}$.

\subsection{Dissolved Oxygen}

Dissolved oxygen (DO) is measured by the operators at the effluent well directly after the chlorine contact chamber. DO is subject to seasonal changes (Figure 6.3). Colder winter weather corresponds to a higher concentration of DO in the water, and warmer weather corresponds to lower DO levels. Low valleys consistently occur during August and high peaks during January. In between these months, DO levels gradually rise or fall. This pattern is typical of DO of water treatment ponds (Metcalf et al. 1991).

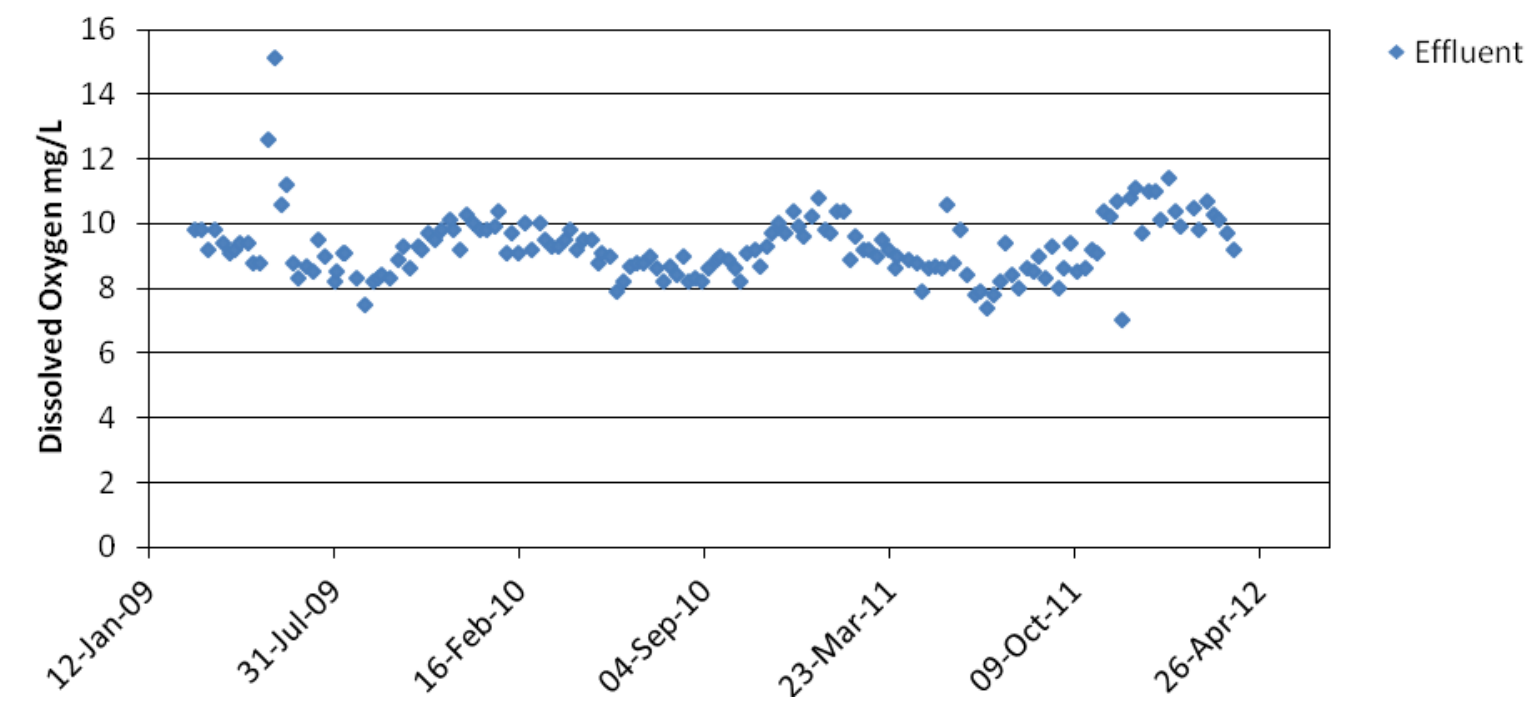

Figure 6.3: Effluent dissolved oxygen concentration at the WWWTP from March 2009 through March 2012, as reported in monthly reports to the RWQCB. 


\section{$6.4 \mathrm{pH}$}

pH was between 6.5 and 8.4 throughout the study period, except for one low value (4.9) and one high value (Figure 6.4). Effluent $\mathrm{pH}$ averaged 7.97. There have been several recorded violations that have been corrected by the operator. By comparing Figure 6.4 to Figure $6.2 \mathrm{a}$, pond $\mathrm{pH}$ fluctuation does not appear to affect tBOD removal. The plant operators installed a pump for citric acid dosing to correct high $\mathrm{pH}$ in April 2010. When this was applied to effluent discharge, the tBOD increased as can be seen in Figure 6.2a.

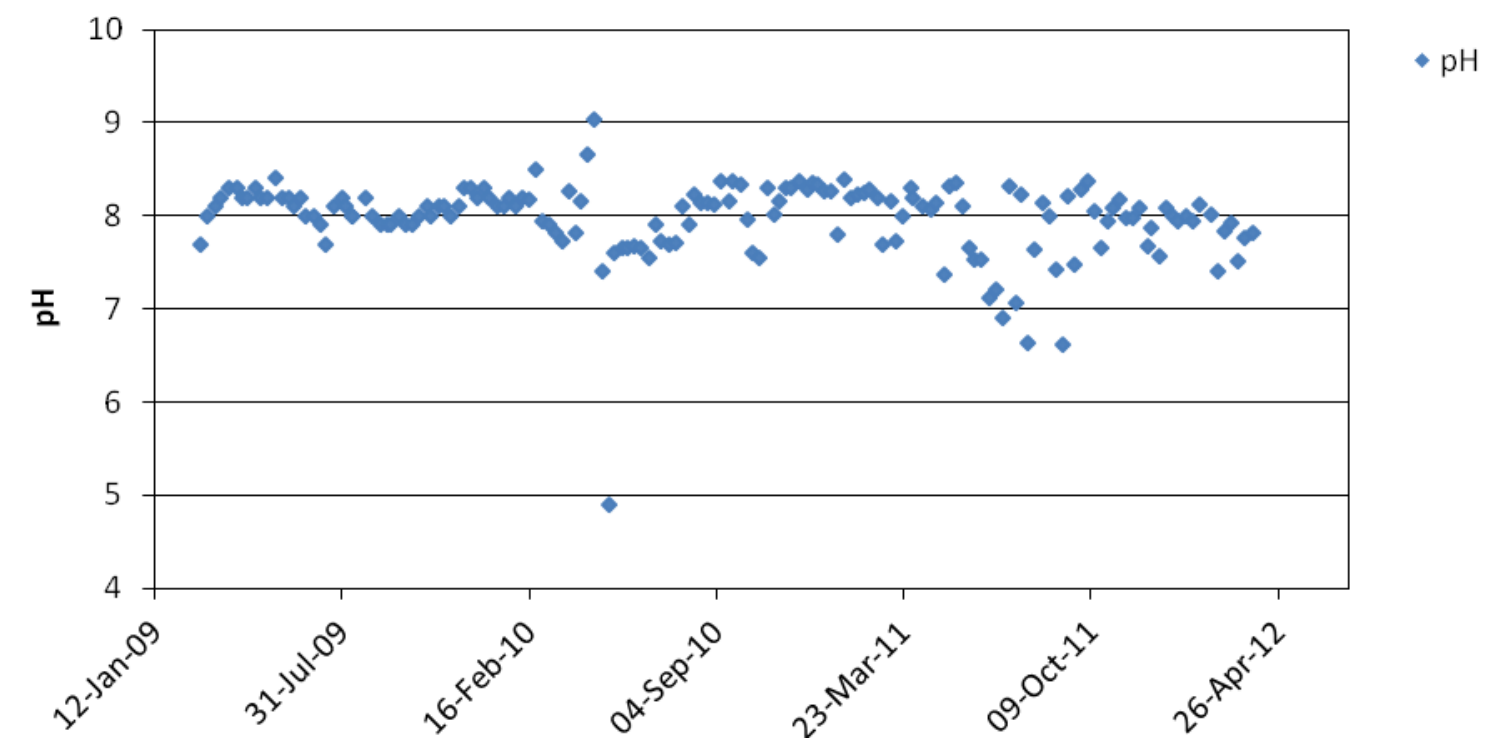

Figure 6.4: Effluent $\mathrm{pH}$ of the WWWTP from March 2009 through March 2012, as reported in monthly reports to the RWQCB.

\subsection{Temperature}

Temperature of the treatment pond varied from $15{ }^{\circ} \mathrm{C}$ in the summers and $10^{\circ} \mathrm{C}$ or below in the winter (Figure 6.5). This relatively small variation in temperature is common to the area of Nipomo California. Temperature data were compiled by CIMIS station 202 Nipomo California. Location of station is in the nearby Monarch Dunes Golf Course. 


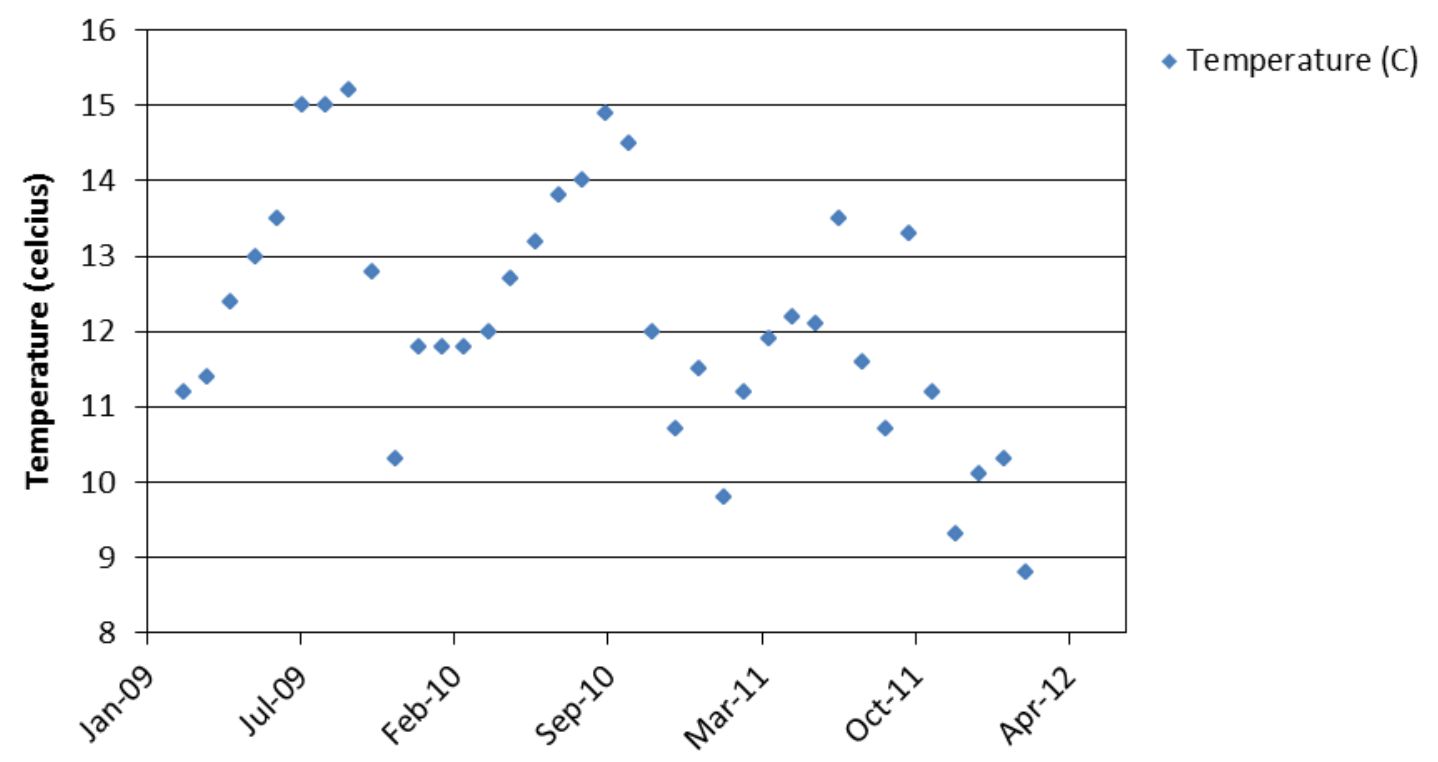

Figure 6.5: Monthly ambient temperature recordings from CIMIS Station 202 in Nipomo California.

Regional temperature effects biological activity in treatment ponds. Algae respond to temperature as well as light to aid in the addition of dissolved oxygen to the pond system. Extreme temperature will limit the biological activity of the treatment pond.

\subsection{Insolation}

Insulation or fog in the area was also recorded and compiled by the CIMIS station 202 in Nipomo. 


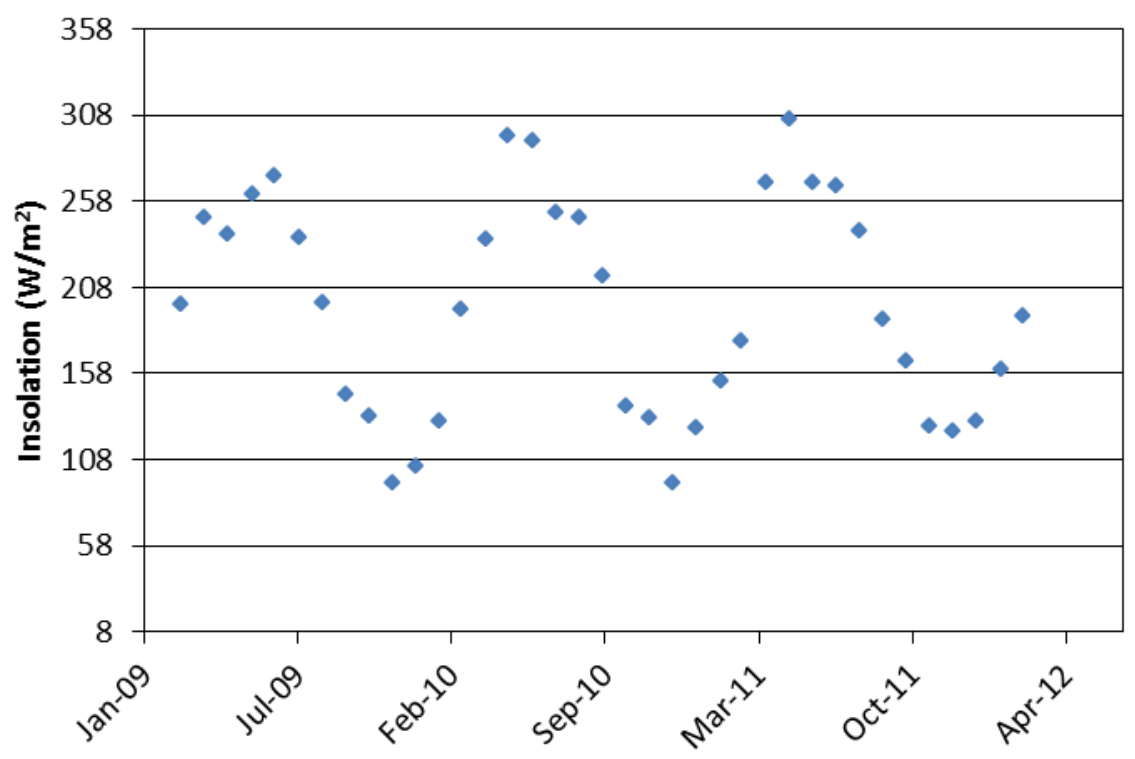

Figure 6.6: Insulation monthly recordings from CIMIS station 202 in Nipomo California.

Fog in Nipomo was very consistent and predictable. Variation between 310 and $105 \mathrm{~W} / \mathrm{m}^{2}$ is consistent between March 2009 and March 2012. Fog will limit sunlight to the area. and decrease the rate at which algae can add dissolved oxygen to the wastewater ponds.

\subsection{Analysis of Historical Data Conclusion}

Biological oxygen demand, total suspended solids, dissolved oxygen, and $\mathrm{pH}$ have shown that since March 2009, the WWWTP is producing effluent that regularly meets the standards set by the RWQCB. 
Table 6.1: Summary of effluent characteristics of the WWWTP (tBOD 5 , TSS, DO and $\mathrm{pH}$ from March 2009 to March 2012 and comparison to regulations set by the RWQCB.

\begin{tabular}{cccc}
\hline Constituent & $\begin{array}{c}\text { Regulatory Limit } \\
\text { (monthly average) }\end{array}$ & $\begin{array}{c}\text { Average } \\
\text { (March 2009- } \\
\text { March-2011) }\end{array}$ & Standard Deviation \\
\hline $\mathrm{tBOD}_{5}$ & $10 \mathrm{mg} / \mathrm{L}$ & 3.0 & 0.8 \\
$\mathrm{TSS}$ & $10 \mathrm{mg} / \mathrm{L}$ & 1.6 & 1.0 \\
$\mathrm{DO}$ & $\mathrm{NA}$ & 9.3 & 1.0 \\
$\mathrm{pH}$ & $6.5-8.4$ & 7.97 & 0.42 \\
\hline
\end{tabular}




\section{CHAPTER 7: WATER QUALITY ANALYSIS: A CLOSER LOOK}

In addition to data collected by the wastewater treatment plant operators, samples were collected on approximately 20 dates between September 2011 and April 2012 and analyzed at Cal Poly. The samples were collected weekly as described in the methods section. In summary, samples were collected at the following locations: inlet of the plant, after each pond, after the microfilter, and at the microfilter backwash outlet to Pond A. Samples were tested for 5-day total carbonaceous soluble BOD, TSS/VSS, total ammonia nitrogen, and alkalinity. Cal Poly laboratory quality control requirements were met for only 20 weeks of 30 weeks of sampling. This section covers the performance of each pond and the microfilter with regards to the acceptable water quality measures.

\subsection{Biological Oxygen Demand}

Figure 7.1a shows clearly that even after the first pond, $\mathrm{csBOD}_{5}$ concentration decreases dramatically to below the regulated limits. Since effluent values cannot be easily discerned from the graph, listed here is the final effluents values for Pond A, B, C, and the microfilter, chronologically from September 2011 to March 2012. 


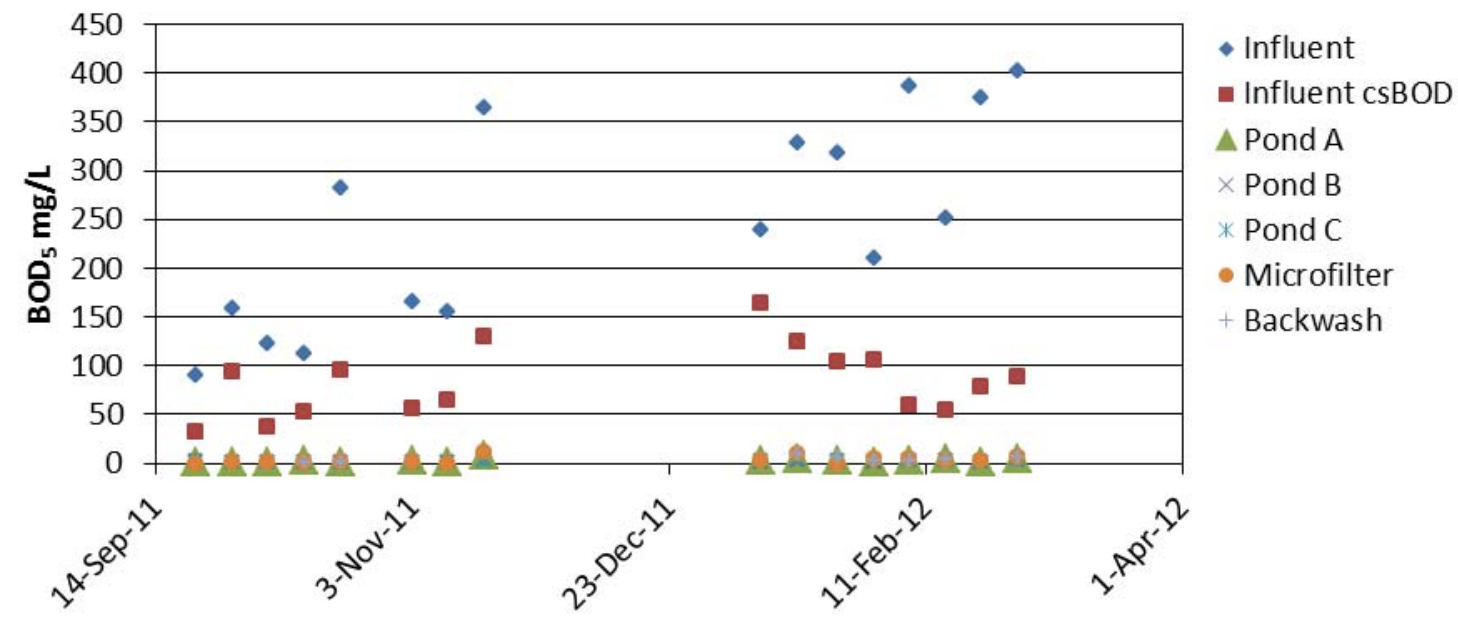

Figure 7.1a: $\operatorname{csBOD}_{5}$ at various locations at the WWWTP from September 2011 through March 2012. Locations include influent (total $\mathrm{BOD}_{5}$ ), influent (carbonaceous soluble $\mathrm{BOD}_{5}$ ), Pond $\mathrm{A}$ effluent, Pond B effluent, Pond C effluent, microfilter effluent, and the microfilter backwash outlet to Pond A.

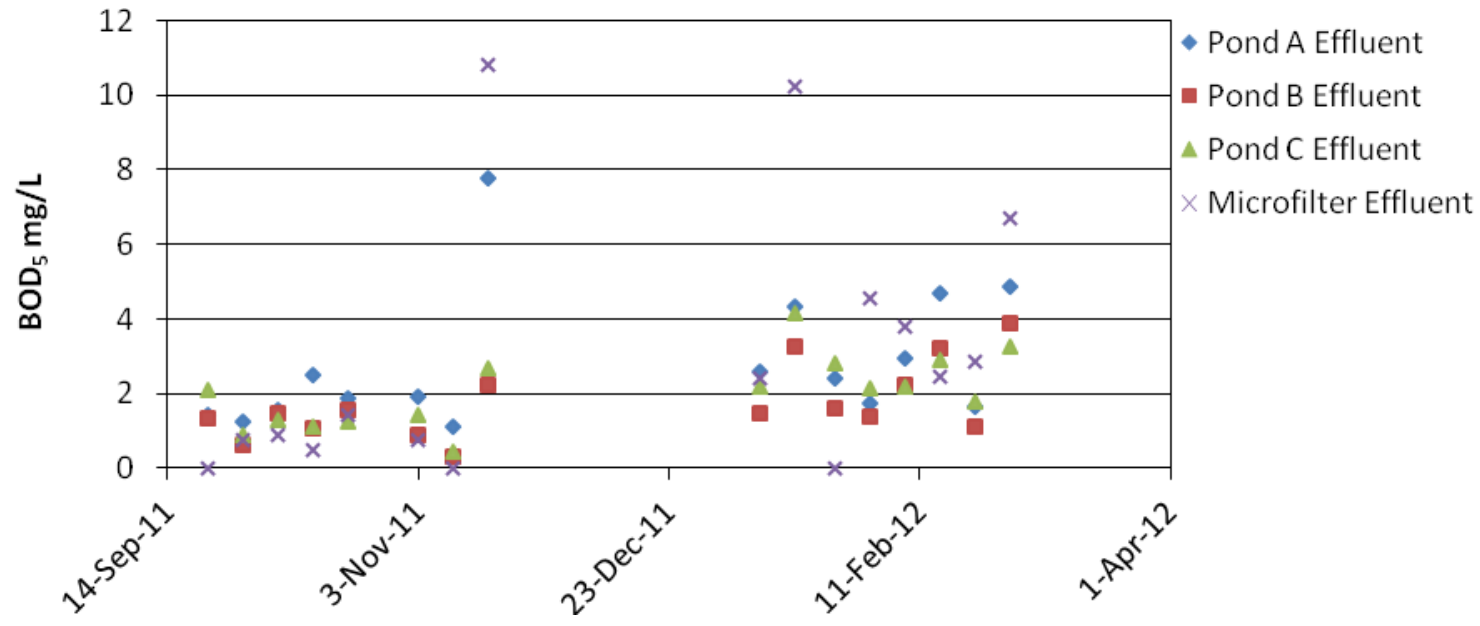

Figure 7.1b: Soluble carbonaceous $\mathrm{BOD}_{5}$ at various locations at the WWWTP from September 2011 through March 2012. Locations include Pond A effluent, Pond B effluent, Pond C effluent, and microfilter effluent. 
Table 7.1: Data of $\operatorname{csBOD}_{5}$ for Pond A, B, C, and the microfilter from September 2011 to March 2012.

\begin{tabular}{cccc}
\hline Pond A & Pond B & Pond C & Microfilter \\
\hline 1.4 & 1.34 & 2.10 & Non-detect \\
1.125 & Non-detect & Non-detect & Non-detect \\
1.56 & 1.45 & 1.28 & Non-detect \\
2.5 & 1.08 & 1.13 & Non-detect \\
1.87 & 1.56 & 1.25 & Non-detect \\
1.91 & Non-detect & 1.42 & 1.41 \\
1.11 & Non-detect & Non-detect & Non-detect \\
7.76 & 2.21 & 2.67 & Non-detect \\
2.6 & 1.48 & 2.2 & 10.83 \\
4.32 & 3.26 & 4.41 & 2.41 \\
2.43 & 1.62 & 2.82 & Non-detect \\
1.73 & 1.39 & 2.15 & 4.54 \\
2.95 & 2.24 & 2.19 & 3.81 \\
4.67 & 3.21 & 2.88 & 2.44 \\
1.67 & 1.12 & 1.8 & Average: 3.01 \\
4.86 & 3.89 & 3.25 & \\
\hline Average: 2.79 & & & 2.87 \\
\hline & & & 2.04 \\
\hline
\end{tabular}

No pattern could be discerned in $\operatorname{csBOD}_{5}$ concentration throughout the treatment system. Concentrations did not decrease consistently with each treatment unit. Instead $\operatorname{csBOD}_{5}$ shows similar levels throughout the WWWTP (Figure 7.1b). On multiple occasions the microfilter 
concentration is higher than concentration in the ponds. The lack of pattern is probably due to analytical uncertainty caused by the concentrations being near the detection limit of the method. Also, it may even be argued that with a residence time of 140 days, Pond A is the only pond necessary for the level of treatment required at current flow.

Table 7.2: Summary of $\operatorname{csBOD}_{5}$ data collected from September 2011 to March 2012. Note that the detection limit for BOD is $1 \mathrm{mg} / \mathrm{L}$.

\begin{tabular}{ccccccc}
\hline Parameter & Limit & Location & Average & High & Low & Std Dev. \\
\hline & & Influent & 83.6 & 162.1 & 32.0 & 36.3 \\
& & Pond A effluent & 2.79 & 7.76 & 1.11 & 1.80 \\
BOD & $10 \mathrm{mg} / \mathrm{L}$ & Pond B effluent & 1.73 & 3.89 & Non-detect & 1.0 \\
& & Pond C effluent & 2.04 & 4.14 & Non-detect & 0.97 \\
& & Microfilter effluent & 3.01 & 10.83 & Non-detect & 3.5 \\
& & Final tBOD effluent & 3.00 & 8.00 & 2.00 & 0.8 \\
\hline
\end{tabular}

The kinetic parameters of csBOD removal by the WWWTP ponds were estimated using a simple model. Each pond was modeled as a separate "continuous-flow stirred tank reactor" (CSTR). The equations below represent the removal kinetics of one CSTR-like treatment pond and the removal efficiency of the pond.

$$
S=\frac{S u}{1+h t} \quad E=\frac{S o-S}{S o} \times 100 \%
$$

Where $\mathrm{S}=\operatorname{csBOD}_{5}$ concentration in $\mathrm{mg} / \mathrm{L}$

So $=$ initial $\operatorname{csBOD}_{5}$ concentration in $\mathrm{mg} / \mathrm{L}$

$\mathrm{k}=$ rate constant

$\mathrm{t}=$ retention time

$\mathrm{E}=$ efficiency 
The initial and final $\operatorname{csBOD}_{5}$ concentrations, retention times, and resulting $\mathrm{k}$ values and efficiencies are summarized in Table7.3. Initial concentrations were found in Table 7.2.

Table 7.3: Summary of kinetic parameters and soluble carbonaceous $\mathrm{BOD}_{5}$ removal efficiency determined from the average data collected during September 2011 to March 2012.

\begin{tabular}{cccccc}
\hline & \multicolumn{3}{c}{ Data } & \multicolumn{2}{c}{ Resulting Parameters } \\
\hline Pond & $\mathbf{S}_{\mathbf{0}}(\mathbf{m g} / \mathbf{L})$ & $\mathbf{S ~ ( m g / L )}$ & $\mathbf{t}$ (days) & $\mathbf{k ~ ( \text { day } ^ { - 1 } )}$ & $\mathbf{E ~ ( \% )}$ \\
$\mathbf{A}$ & 248 & 2.79 & 140 & 0.63 & 98.9 \\
$\mathbf{B}$ & 2.79 & 1.73 & 84 & 0.007 & 38 \\
$\mathbf{C}$ & 1.73 & 2.04 & 70 & $<0$ & $<0$ \\
\hline
\end{tabular}

Effluent concentrations from Pond A are already below the discharge limit, confirming that only Pond A is necessary for the treatment of the current load from the Woodlands community.

Pond B performed much poorer than Pond A with a removal parameter k of $0.007 \mathrm{day}^{-1}$ and efficiency of $38 \%$. The fact that $\operatorname{csBOD}_{5}$ concentration in Pond C increased suggests that it is also unnecessary for treatment under the current load conditions. However, the existence of Ponds $\mathrm{B}$ and $\mathrm{C}$ is justified to meet typical areal BOD loading guidelines at build-out.

\subsection{Suspended Solids}

Total suspended solids and volatile suspended solids concentrations during September 2011 through March 2012 are shown in Figure 7.3. The gaps in the data series were due to analytical batches that did not pass laboratory quality control. In general TSS and VSS decreased as the water traveled from Pond A to B to C (Figure 7.3 and 7.4). Microfilter concentrations were 
consistently undetectable. The general trend of solids in the ponds is that the solids increased from winter to spring, presumably due to algal growth.

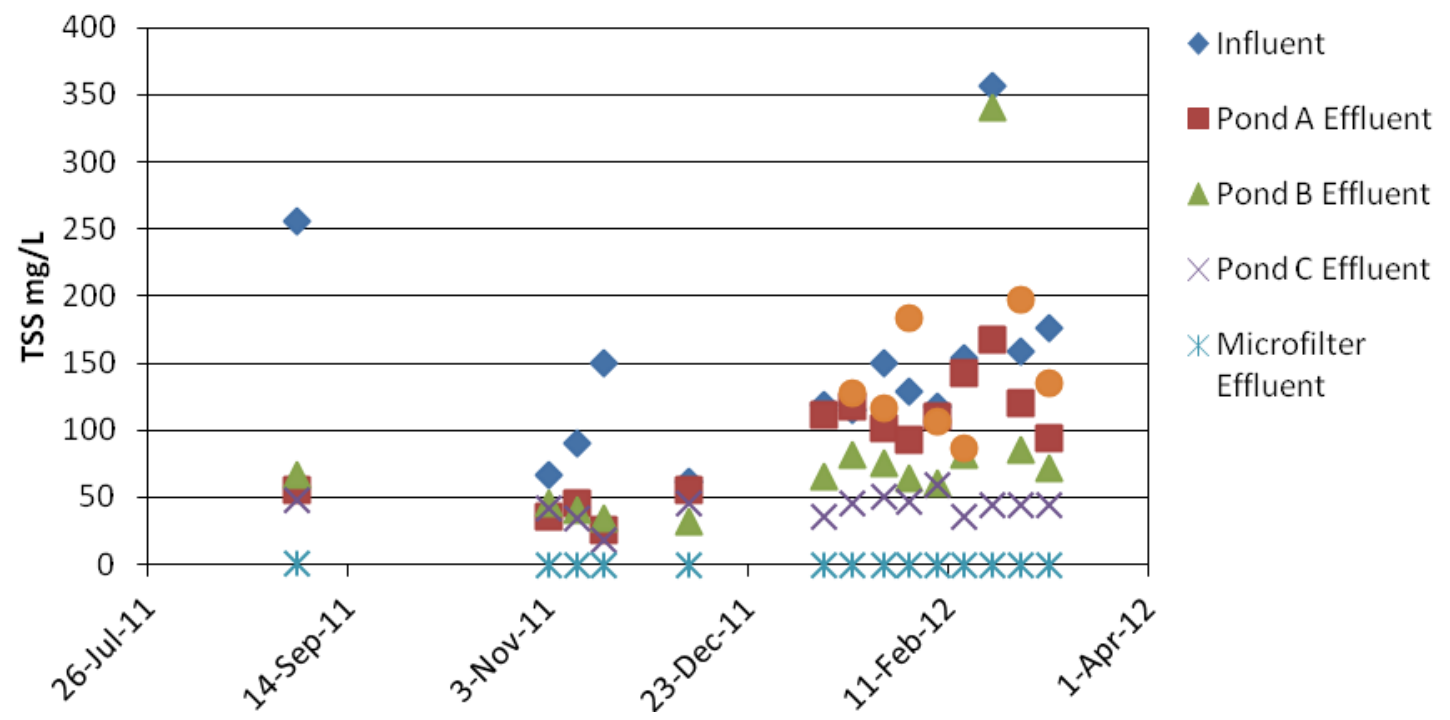

Figure 7.2: TSS at various locations at the WWWTP from September 2011 through March 2012. The sample locations were the Influent, Pond A effluent, Pond B effluent, Pond C effluent, and microfilter effluent.

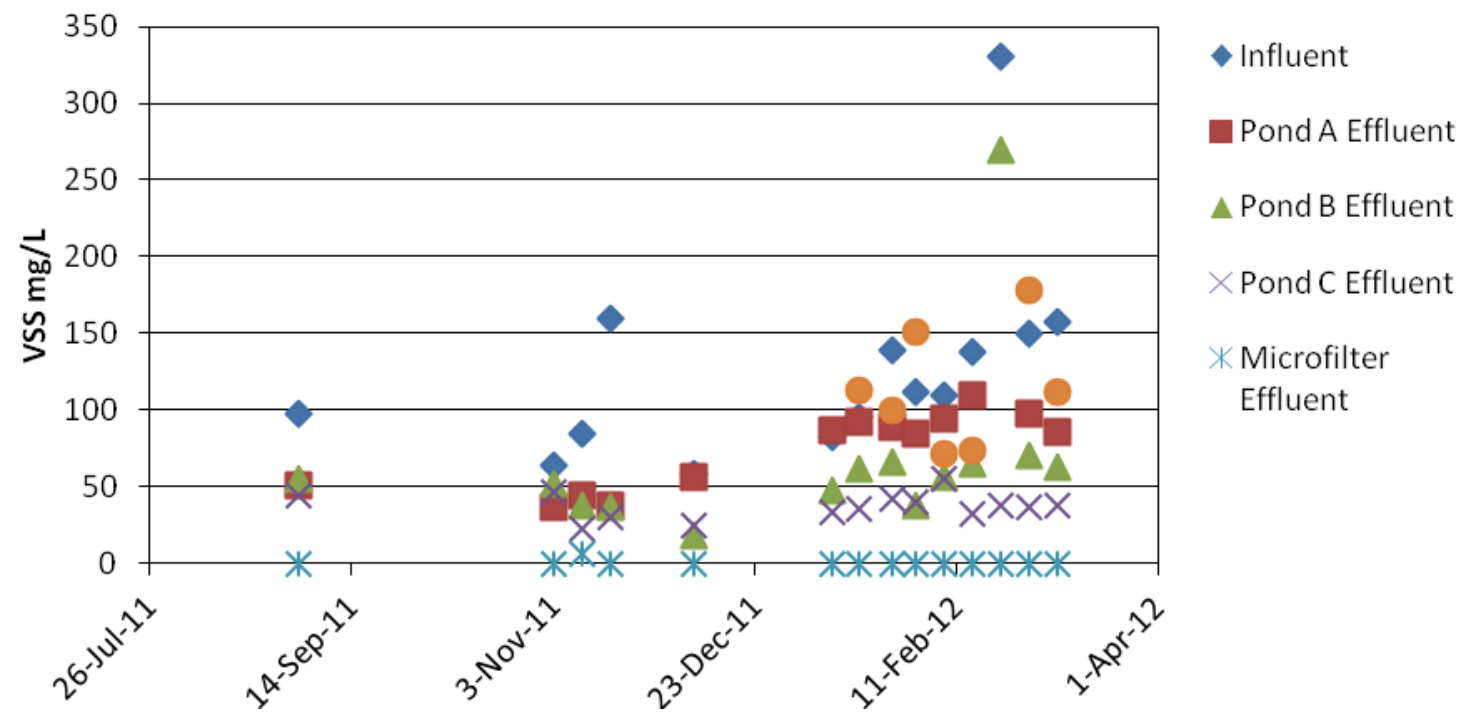

Figure 7.3: VSS at various locations at the WWWTP from September 2011 through March 2012. The sample locations include Influent, Pond A effluent, Pond B effluent, Pond C effluent, and microfilter effluent 
Table 7.4: Summary of TSS data collected from September 2011 to March 2012.

\begin{tabular}{|c|c|c|c|c|c|c|}
\hline Parameter & Limit & Location & Average & High & Low & Std Dev. \\
\hline & & Influent & 150.1 & 357 & 62 & 76.8 \\
\hline & & Pond A effluent & 91.2 & 168 & 26 & 41.9 \\
\hline \multirow[t]{4}{*}{ TSS } & $10 \mathrm{mg} / \mathrm{L}$ & Pond B effluent & 81.5 & 340 & 32 & 76.4 \\
\hline & & Pond C effluent & 42.4 & 59 & 18 & 9.6 \\
\hline & & $\begin{array}{c}\text { Microfilter } \\
\text { effluent }\end{array}$ & .02 & .31 & 0 & 0.08 \\
\hline & & Final effluent & 1.57 & 6 & 1 & 0.095 \\
\hline
\end{tabular}

\subsection{Total Ammonia Nitrogen (TAN)}

Nutrient removal is not monitored at the wastewater treatment plant because there is no regulatory limit on nutrients for discharged wastewater. However, total ammonia nitrogen (TAN) was monitored for the present thesis.

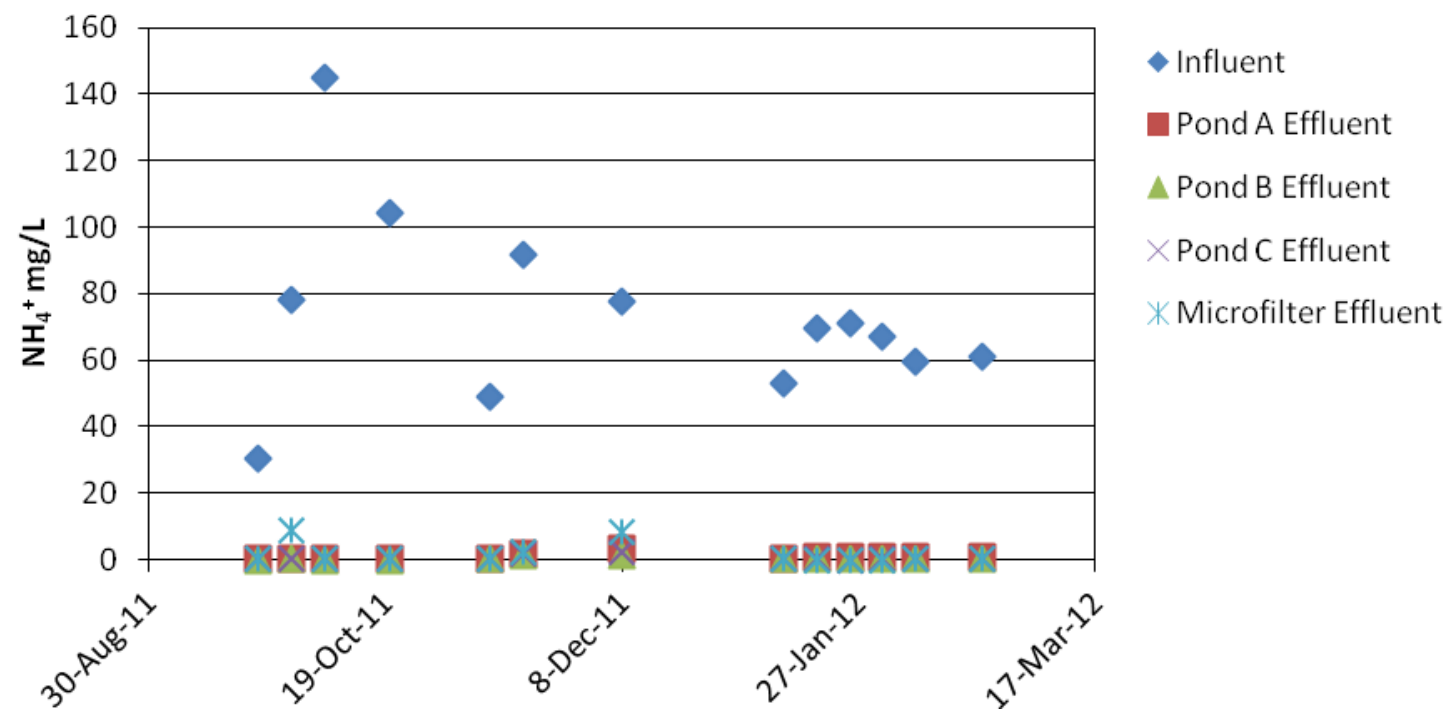

Figure 7.4: Total ammonia nitrogen (TAN; $\mathrm{NH}_{3}+\mathrm{NH}_{4}{ }^{+}$) at various locations at the WWWTP from September 2011 through March 2012. Locations include Influent, Pond A effluent, Pond B effluent, Pond C effluent, and microfilter effluent. 
The ponds at WWWTP decrease the average TAN concentrations from an average of $68.5 \mathrm{mg} / \mathrm{L}$ to less than $1 \mathrm{mg} / \mathrm{L}$. The possible routes of TAN removal include ammonia volatilization, ammonia assimilation in microbial biomass especially in algae, and nitrification.

Table 7.5: Summary of TAN data collected from September 2011 to March 2012.

\begin{tabular}{ccccccc}
\hline Parameter & Limit & Location & Average & High & Low & Std Dev. \\
& & Influent & 73.7 & 145 & 30.5 & 28.5 \\
& & Pond A effluent & 0.80 & 3.44 & 0.05 & 1.0 \\
TAN & N/A & Pond B effluent & 0.3 & 1.43 & 0.01 & 0.5 \\
& & Pond C effluent & 0.43 & 2.24 & 0.04 & 0.74 \\
& & Microfilter effluent & 1.61 & 9.07 & 0.03 & 3.2 \\
& & Final effluent & $\mathrm{n} / \mathrm{a}$ & $\mathrm{n} / \mathrm{a}$ & $\mathrm{n} / \mathrm{a}$ & $\mathrm{n} / \mathrm{a}$ \\
& & & & & &
\end{tabular}

\subsection{Alkalinity}

Influent alkalinity appeared to follow a seasonal pattern and is reduced in the pond system. Alkalinity was reduced in Pond A and did not change substantially in the locations that followed (Figure 7.6). Once in the pond system, alkalinity does not change from pond to pond, indicating that BOD treatment or biological activity of the ponds does not affect the alkalinity as time and progresses. Comparing Figure 7.6 and Figure 6.8 shows that as $\mathrm{pH}$ decreases due to seasonal changes, alkalinity also decreased. 


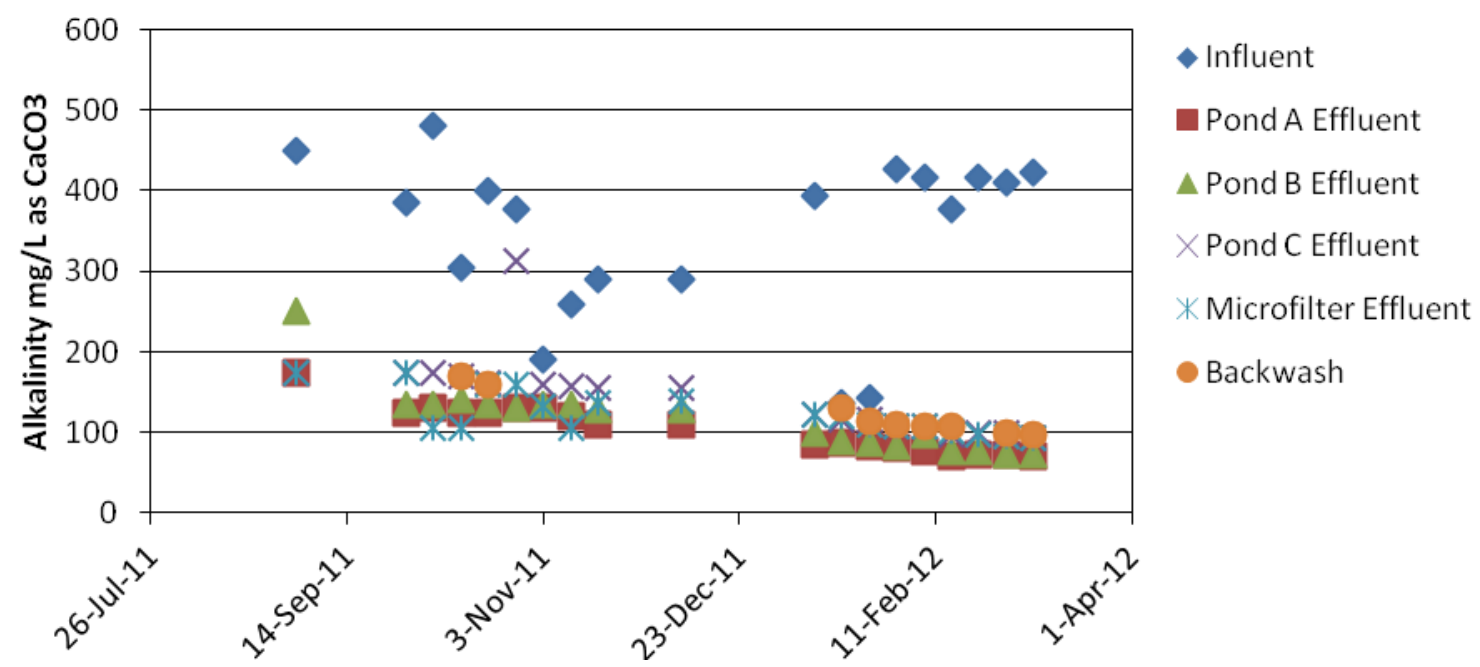

Figure 7.5: Alkalinity as $\mathrm{mg} / \mathrm{L} \mathrm{CaCO}_{3}$ at various locations at the WWWTP from September 2011 through March 2012. Locations include Influent, Pond A effluent, Pond B effluent, Pond C effluent, and microfilter effluent.

Table 7.6: Summary of ALK data collected from September 2011 to March 2012.

\begin{tabular}{ccccccc}
\hline Parameter & Limit & Location & Average & High & Low & Std Dev. \\
\hline \multirow{2}{*}{ ALK } & Influent & 345.9 & 480 & 137 & 102.4 \\
& Nond A effluent & 104.1 & 175 & 70 & 29.2 \\
& & Pond B effluent & 116.2 & 250 & 73 & 41.3 \\
& Pond C effluent & 145.2 & 312.5 & 93 & 50.6 \\
& & Microfilter effluent & 123.5 & 175 & 93 & 27.0 \\
& & Final effluent & $\mathrm{n} / \mathrm{a}$ & $\mathrm{n} / \mathrm{a}$ & $\mathrm{n} / \mathrm{a}$ & $\mathrm{n} / \mathrm{a}$ \\
& & & & & \\
\end{tabular}

\subsection{Sludge Production}

Non-biodegradable settleable solids accumulate in treatment ponds. However, the sludge production of normally operating domestic wastewater treatment ponds becomes a problem only after many years of operation (Nelson 2004). The sludge production of the Woodlands wastewater treatment plant was expected to be minimal because of the low load to the pond 
system. Sludge buildup at the Woodlands ponds was measured by taking sludge depth measurements in 22 locations in the three ponds. The measurements were made by FRM staff. A diagram of these locations and their corresponding sludge depth buildup is shown in Figure 7.6.

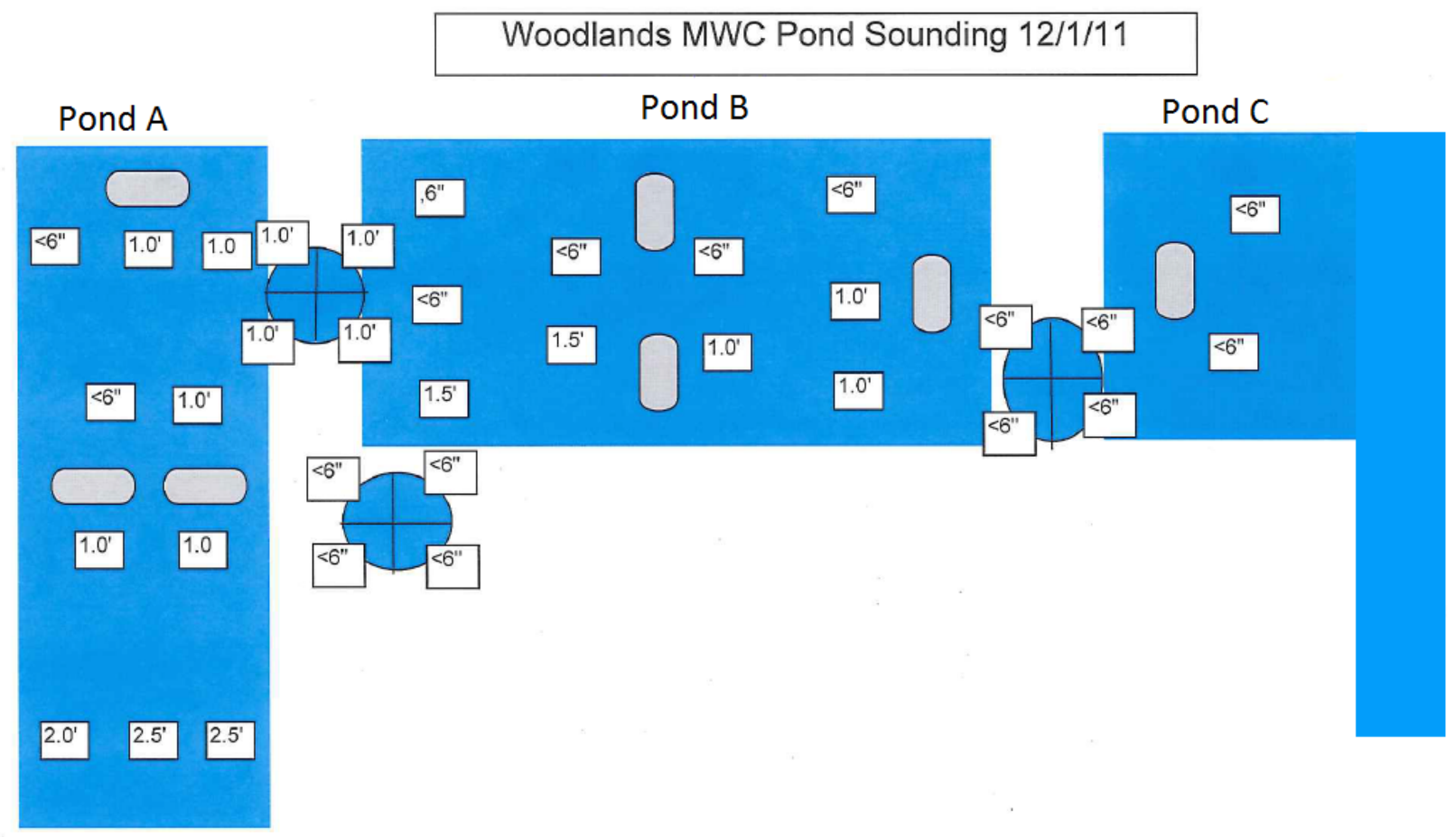

Figure 7.6: Diagram of sludge depth in feet at 22 locations in the pond system at the Woodlands Wastewater Treatment Plant. The circles represent locations of rotor aerators. Diagram supplied by FRM.

Sludge buildup in the pond system averaged about one foot overall. Influent wastewater enters Pond $\mathrm{A}$ at the lower left hand corner of the image in Figure 7.6 and flows upward. More sludge was observed at this point near the influent, as expected because a digester zone was been constructed by installing a vinyl sheet piling curtain that separates approximately the first third of Pond A from the rest. This barrier limits the turbulence to the area occupied by the aerators, minimizing re-suspension and dispersion of settled waste. The digester zone contains approximately 2.5 feet of solids buildup, indicating that the curtain wall was successful in trapping sludge in the digester zone. Outside of the digester zone, one foot or less of sludge has 
accumulated in Pond A. Similarly, Pond B has a digester zone at the inlet of the pond, but sludge has not accumulated here more than anywhere else in Pond B. Pond B uniformly had between 0.5 and 1.5 feet of sludge depth. Pond $\mathrm{C}$ had even less solids accumulation. Sludge accumulation rate for the aerobic and anaerobic (digester) portions of the treatment ponds were found by averaging the sludge depths (Figure 7.6) and dividing by 3 years. Sludge rates were compared to a range of typical sludge accumulation rates (Nelson 2004).

Table 7.7: Measured sludge accumulation rates compared to typical ranges in the WWWTP system from March 2009 to March 2012.

\begin{tabular}{cccc} 
& Pond & $\begin{array}{c}\text { Sludge Accumulation } \\
\text { Rate (in/yr) }\end{array}$ & Typical Range \\
\hline Aerobic & A & 3.44 & $0.27-3.35$ \\
& B & 3.44 & \\
\hline Anaerobic & C & 2 & $2.0-4.70$ \\
& A & 4.66 & \\
\hline
\end{tabular}

Sludge rates in the aerobic regions of ponds A and B are slightly higher than the high end of typical values, and also at the high end of the typical range for anaerobic ponds (Table 7.6). At the rate suggested by Table 7.6, and ignoring the need for treatment volume, Ponds A and B would completely fill in with sludge in 52 years and Pond C in 99 years.

\subsection{Algal Species}

The pond system relies partly on algae to provide the oxygen used by aerobic heterotrophic bacteria, which contribute to BOD removal. Variability of algal species in the Woodlands treatment system was variable. Large populations of the following species were observed in the 
ponds. These species represent the largest populations of algae within Ponds A, B, and C, as the variation of species population between ponds is minimal. The main species present in the Woodlands pond system are listed and pictured below along with micrographs of each.

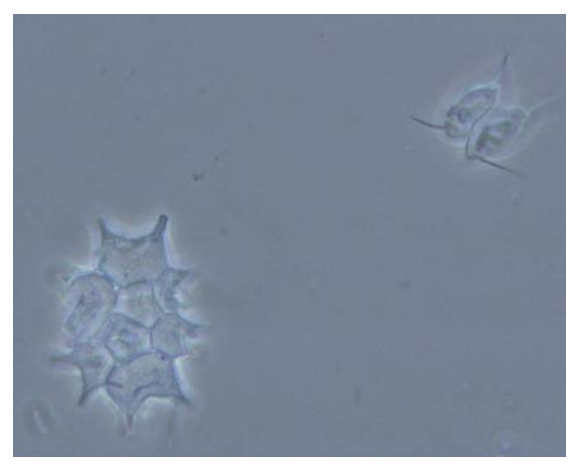

Pediastrum and Scenedesmus 1000x

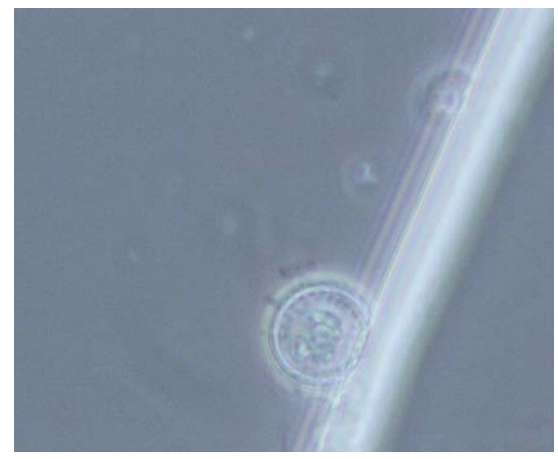

Cyclotella 1000x

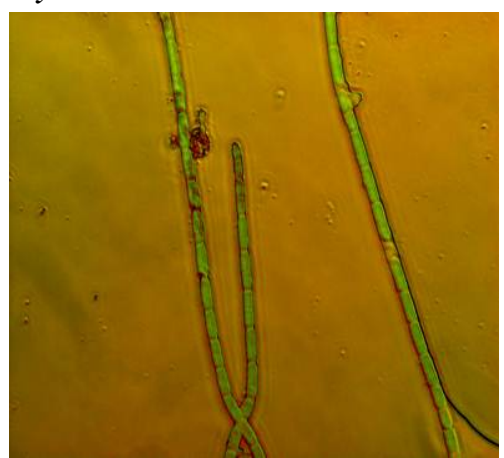

Cladophora 400x

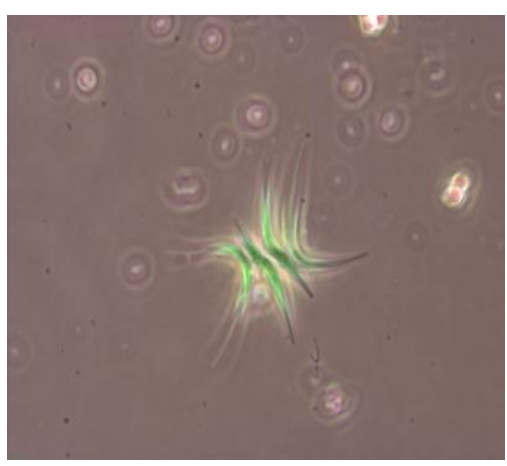

Ankistodesmus 100x

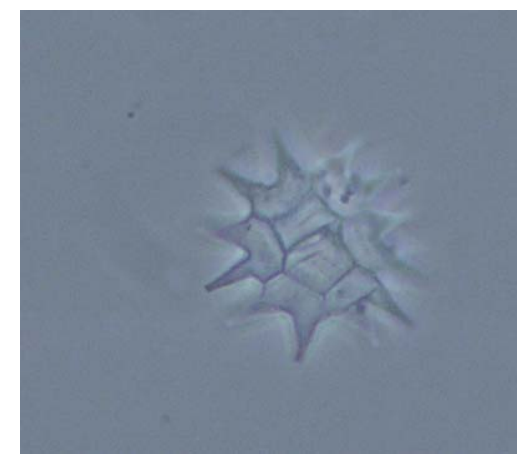

Pediastrum 1000x

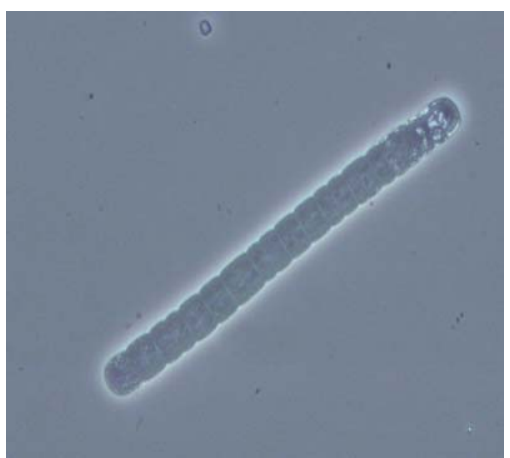

Oscillatoria $1000 \mathrm{x}$

Figure 7.7: Tentative identification of algae present in the effluent of Pond C on June 5, 2012. 


\subsection{Microfiltration}

Influent solids load on microfilters increases the fouling rate of the membranes. To evaluate microfilter efficiency and possible fouling this fouling, microfilter effluent samples and Pond C effluent samples were collected and tested for approximately 20 weeks (Figure 7.8).

The average influent TSS concentration of the microfilters was $42.5 \mathrm{mg} / \mathrm{L}$ (Pond C effluent), and the microfilter effluent concentration was $1.6 \mathrm{mg} / \mathrm{L}$ with a standard deviation of $1 \mathrm{mg} / \mathrm{L}$ which is $96 \%$ removal. These values were found using the value of 1 for those values recorded as $<1$. The detection limit reported in the monthly RWQCB reports changed. Before August 2011, undetectable levels were recorded as $<1 \mathrm{mg} / \mathrm{L}$. After August 2011, undetectable levels are recorded as $<3 \mathrm{mg} / \mathrm{L}$. There is no recorded reason for the difference in recording conventions.

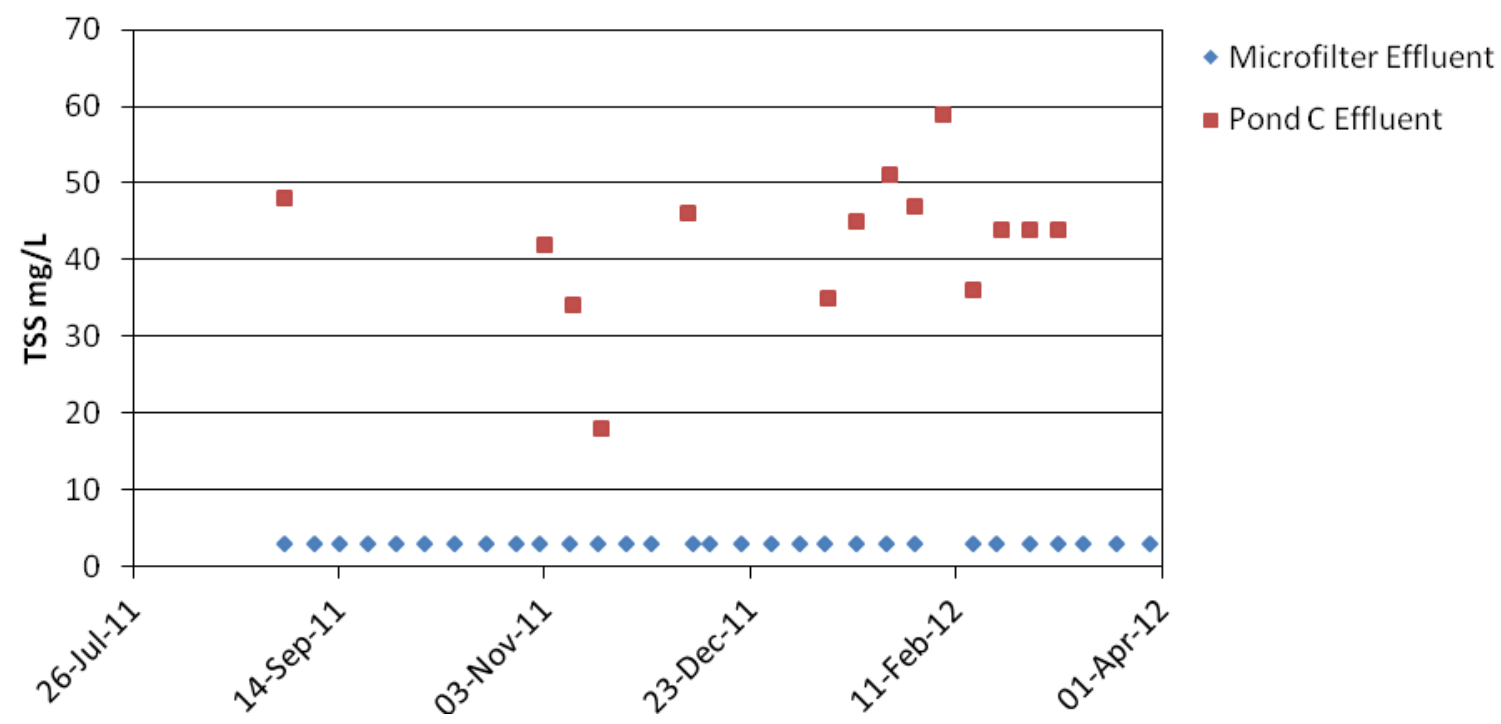

Figure 7.8: TSS influent and effluent of the WWWTP microfilters from September 2011 through March 2012, as recorded in monthly reports to the RWQCB. All data points shown as 1 $\mathrm{mg} / \mathrm{L}$ were recorded as $<1 \mathrm{mg} / \mathrm{L}$ in the monthly report. 


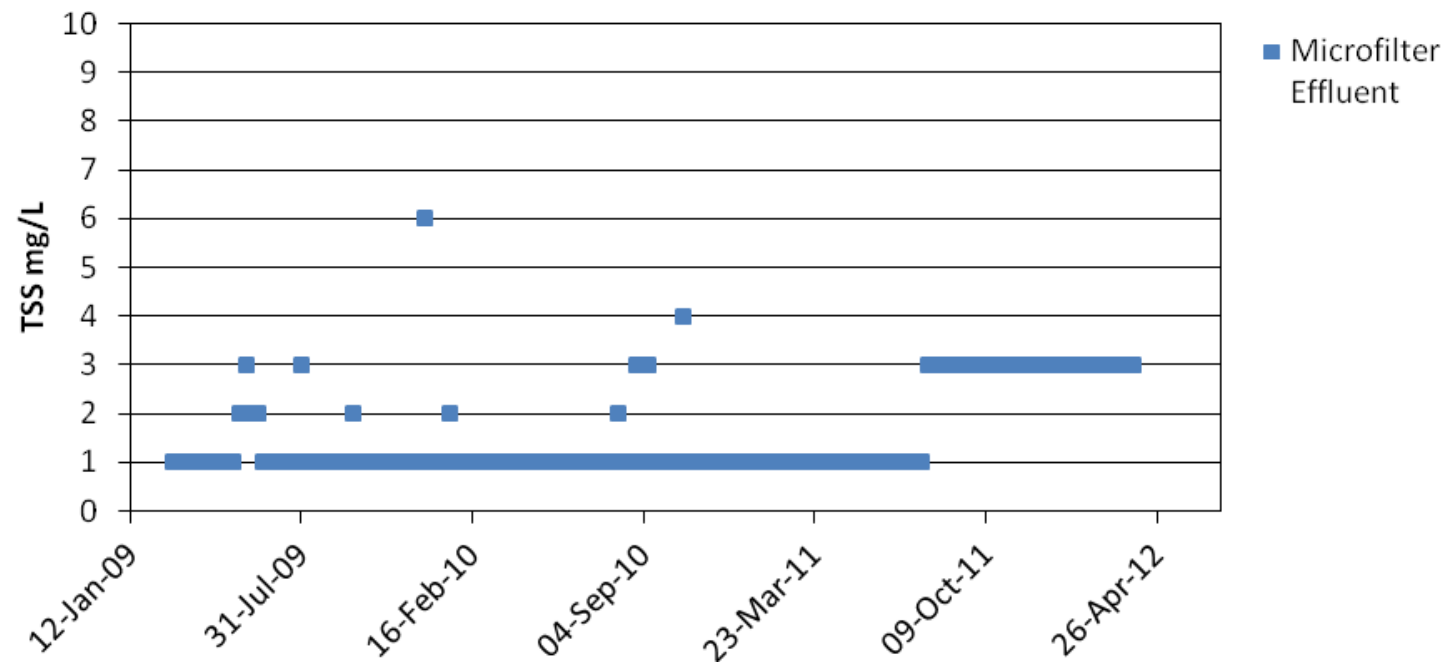

Figure 7.9: TSS effluent of the WWWTP microfilters from March 2009 through March 2012, as reported in monthly reports to the RWQCB. All data points shown as $1 \mathrm{mg} / \mathrm{L}$ were reported as $<1 \mathrm{mg} / \mathrm{L}$ in the monthly reports.

Attempts were made to evaluate fouling based on pressure drops. However, numerical data were impossible to download from the pressure recording system that monitors microfilter operation. However, by observation of the recorded pressure readings on the datalogger monitor, it was seen that normal operating pressure was regularly between 2 and 4 psi. Small fluctuations were observed within this range. During summertime, operating pressure was elevated but returns to 2.5-3.0 psi after a chemical cleaning. Since chemical cleaning is conducted on an as-needed basis, it is the responsibility and judgment of the plant operations manager to initiate a chemical cleaning. Even though backwashes and chemical cleanings are performed regularly, permanent fouling of the membranes is expected eventually. However, for the three years that the Woodlands treatment plant has been operating, no permanent increase in headloss has been observed. Daily load on the microfilters was found to be $80.9 \mathrm{~L} / \mathrm{m}^{2}$ of membrane and $3 \mathrm{~g}$ $\mathrm{TSS} / \mathrm{m}^{2}$ of membrane each day. Flow to the filter membrane fell in at the high end of typical values of $30-170 \mathrm{~L} / \mathrm{m}^{2} /$ day, for the microfiltration processes (MWH 2005). 


\section{CHAPTER 8: ELECTRICITY USE}

\subsection{Overall Energy Use}

The major pieces of electrical equipment on the PG\&E meter at the WWWTP were the following Items: (1) influent grinder and auger, (2) a recirculation pumps, (3) pond aerators, (4) Pond $\mathrm{C}$ lift pump to the microfilter, (5) two chemical dosing pumps, (6) microfilter influent pressure pump, (7) controls for all mechanical units, and (8) the effluent pump. Total energy consumption and cost for the entire plant was determined from utility bills (Table 8.1) and used to assess overall energy efficiency of the WWWTP. Billing data from PG\&E shows that the total energy consumed by the treatment plant was $214,680 \mathrm{kWh}$ during 2011 , which cost $\$ 36,998$. The annual average inflow, based on the monthly RWQCB reports, was 25,000 gpd or 9.125 MG per year. In 2011, based on the 9.125 MG per year flow, the energy intensity was $23,500 \mathrm{kWh}$ per MG treated, and the cost of electricity for this treatment was $\$ 4,100$ per MG $(\$ 0.173 / \mathrm{kWh})$. These results are discussed and compared to conventional treatment at the end of this section.

Table 8.1: WWWTP energy consumption and cost during 2011 (Source: PG\&E bills).

\begin{tabular}{ccc}
\hline Month & kWh & Cost \\
\hline Jan-11 & 17,400 & $\$ 2,555.12$ \\
Feb-11 & 21,960 & $\$ 3,223.93$ \\
Mar-11 & 16,560 & $\$ 2,459.76$ \\
Apr-11 & 19,680 & $\$ 3,013.72$ \\
May-11 & 19,560 & $\$ 3,875.09$ \\
Jun-11 & 17,280 & $\$ 3,425.46$ \\
Jul-11 & 13,800 & $\$ 2,736.68$ \\
Aug-11 & 18,000 & $\$ 3,566.20$ \\
\hline
\end{tabular}




\begin{tabular}{ccc}
\hline Sep-11 & 17,520 & $\$ 3,471.93$ \\
Oct-11 & 16,320 & $\$ 3,235.48$ \\
Nov-11 & 17,760 & $\$ 2,637.97$ \\
Dec-11 & 18,840 & $\$ 2,796.65$ \\
Total & $\mathbf{2 1 4 , 6 8 0}$ & $\$ \mathbf{3 6 , 9 9 7 . 9 9}$ \\
\hline
\end{tabular}

Table 8.2: Total WWWTP energy data summary for 2011.

\begin{tabular}{cc}
\hline Energy consumption (kWh/year) & 214,680 \\
Cost (dollars/year) & 36,998 \\
Flow (MG/Year) & 9.125 \\
Energy intensity (kWh/MG) & 23,500 \\
Cost (gallons/dollar) & 250 \\
\hline
\end{tabular}

\subsection{Aeration Energy Use}

The treatment ponds are aerated daily to increase the concentration of dissolved oxygen in the ponds. Figure 3.3 shows the location of the aerators (Item 3) in the pond system. DO meters positioned throughout the ponds continuously monitor the oxygen levels in the ponds. When the concentration drops below the values noted (Table 8.3), the aerators turn on. When the dissolved oxygen has increased in the ponds sufficiently, the aerators turn off. The whole system is controlled automatically by computers on site at the treatment plant. The pond aerators have a combined nameplate power rating of 57.5 HP (Table 8.1). Although the aerators may consume more electricity than any other component at the plant, their operation times are not recorded. An estimate of aerator energy consumption is calculated by difference in a later section. The energy use of the other equipment on the list is estimated in the follow sections. 
Table 8.3: Summary of aerator motor nameplate power and operating settings in each pond at the WWWTP.

\begin{tabular}{cccccc}
\hline & \multicolumn{2}{c}{ Motor Nameplate Power } & \multicolumn{2}{c}{ Dissolved Oxygen Trigger Levels } \\
\hline Aerator & Pond A & Pond B & Pond C & Turn On (mg/L) & Turn Off (mg/L) \\
\hline $\mathbf{1}$ & $10 \mathrm{HP}$ & $7.5 \mathrm{HP}$ & $7.5 \mathrm{HP}$ & 2.0 & 2.5 \\
$\mathbf{2}$ & $10 \mathrm{HP}$ & $7.5 \mathrm{HP}$ & none & 2.0 & 2.3 \\
$\mathbf{3}$ & $7.5 \mathrm{HP}$ & $7.5 \mathrm{HP}$ & none & 2.0 & \\
Total Each & $27.5 \mathrm{HP}$ & $22.5 \mathrm{HP}$ & $7.5 \mathrm{HP}$ & & \\
Total All & $57.5 \mathrm{HP}$ & & & & \\
\hline
\end{tabular}

\subsection{Estimated Energy Use by Equipment}

The grinder and auger (Item 1) at the treatment plant influent operates based on flow and is low compared to build-out of the treatment plant. It is considered to consume a negligible amount of power at the WWWTP.

A recirculation pump (Item 2) maintains the water level of Ponds A and B. The pump is 460 Volts, 7 amps, and 5 HP, and operates 8 hours per day, returning water from the outlet of Pond B to Pond A. If the motor was specified using typical electrical engineering factors, the following equation can be used to roughly estimate power consumption based on motor nameplate information (pers. comm., T. Lundquist).

$$
\text { Power Estimate }=\mathrm{V} * \mathrm{~A} * 3^{1 / 2} * \mathrm{PF} * \mathrm{SF} * \operatorname{Load}
$$

Where the power estimate is in Watts.

$\mathrm{V}$ is the voltage

$\mathrm{A}$ is the amperage

$\mathrm{PF}$ is an assumed power factor of 0.85 
$\mathrm{SF}$ is the service factor assumed to be 0.80

Load factor is 1 for constant pump operation.

$$
\mathrm{P}=(460) *(7) * 3^{1 / 2 *}(0.85) *(0.80) *(1)=3,793 \mathrm{~W}
$$

$3,793 \mathrm{~W}$ for $8 \mathrm{hrs} /$ day is $11,075 \mathrm{kWh} / \mathrm{yr}$.

Item 3 is the aerator. We will solve for the energy consumed by the aerators in this section.

For the microfilter influent lift station pump from Pond C (Item 4), we assume a flow rate equal to that of the microfilter: $100 \mathrm{gpm}$ or $0.0063 \mathrm{~m}^{3} / \mathrm{sec}$. The elevation gain was determined to be approximately 16 feet or $5 \mathrm{~m}$. Friction losses are not considered in this power approximation.

$$
\mathrm{P}=\mathrm{Q} \gamma \mathrm{H} / \mathrm{e}
$$

Where $\mathrm{P}=$ power in watts

$\mathrm{Q}$ is the flowrate in $\mathrm{m}^{3} / \mathrm{sec}$

$\gamma$ is the specific gravity in $\mathrm{N} / \mathrm{m}^{3}$

$\mathrm{H}$ is the vertical lift of the water

$\mathrm{e}$ is the efficiency of the pump, assumed to be 0.7

$\mathrm{P}=\left(0.0063 \mathrm{~m}^{3} / \mathrm{sec}\right) *\left(9806 \mathrm{~N} / \mathrm{m}^{3}\right) *(5 \mathrm{~m}) / 0.7=441 \mathrm{~W}$

$441 \mathrm{~W}$ for $72 \mathrm{hr} / \mathrm{wk}$ of microfiltration is $1,652 \mathrm{kWh} / \mathrm{yr}$.

Chemical dosing pumps (Item 5) are considered to be negligible. 
The Pall Aria AP-4 microfilter system uses a centrifugal pump (Item 6: G\&L Pumps Model No. $65 \mathrm{Hk} 6,20 \mathrm{HP}, 460 \mathrm{~V}, 23 \mathrm{~A}$; these values used in the equation below) for influent and backwash pumping. The microfilter is typically in operation for 72 hours each week. Using the same equation for power as Item 2, we can solve for an estimation of the microfilter energy use.

$$
\text { Power Estimate }=\mathrm{V} * \mathrm{~A} * 3^{1 / 2} * \mathrm{PF} * \mathrm{SF} * \mathrm{Load}
$$

Where the power estimate is in Watts.

$\mathrm{V}$ is the voltage

A is the amperage

$\mathrm{PF}$ is an assumed power factor of 0.85

SF is the service factor assumed to be 0.80

Load factor is 1 for constant microfilter operation.

$$
\mathrm{P}=(460) *(23) * 3^{1 / 2} *(0.85) *(0.80) *(1)=12,400 \mathrm{~W}
$$

$12.4 \mathrm{~kW}$, for 72 hours per week of microfilter operation is $42,854 \mathrm{kWh} /$ year.

Controls for the mechanical units (Item 7) are considered to be negligible.

For the effluent pump (Item 8), we assume a flow rate equal to that of the microfilter: $100 \mathrm{gpm}$ or $0.0063 \mathrm{~m}^{3} / \mathrm{sec}$. Elevation gain was determined to be about 60 feet or approximately $19 \mathrm{~m}$. For this estimate of power usage, we neglect friction losses.

$$
\mathrm{P}=\mathrm{Q} \gamma \mathrm{H} / \mathrm{e}
$$

Where $\mathrm{P}=$ power in watts

$\mathrm{Q}$ is the flowrate in $\mathrm{m}^{3} / \mathrm{sec}$

$\gamma$ is the specific gravity in $\mathrm{N} / \mathrm{m}^{3}$ 
$\mathrm{H}$ is the vertical lift of the water

e is the efficiency of the pump, assumed to be 0.7

$\mathrm{P}=\left(0.0063 \mathrm{~m}^{3} / \mathrm{s}\right) *\left(9806 \mathrm{~N} / \mathrm{m}^{3}\right)^{*}(19 \mathrm{~m}) / 0.7=1676 \mathrm{~W}$

$1676 \mathrm{~W}$ for $72 \mathrm{hr} / \mathrm{wk}$ of effluent pump operation is $6,275 \mathrm{kWh} / \mathrm{yr}$.

The energy required for the aerators can be estimated with the following equation based on the equipment list in the first paragraph of this chapter:

Aerator energy $=$ Total energy use - Grinder/auger - Recirculation pump - Pond C lift pump - Chemical dosing pumps - Microfilter influent pump - Controls - Effluent pump Assuming that the auger and grinder unit, chemical dosing pumps, and the controls have negligible energy use, the equation for annual aerator energy use simplifies to the following:

Aerator energy $=$ Total energy use - Recirculation pumps - Pond C lift pumpMicrofilter influent pump - Effluent pump

Aerator energy $=214,680 \mathrm{kWh}-11,075 \mathrm{kWh}-1,652 \mathrm{kWh}-42,854 \mathrm{kWh}-6,275 \mathrm{kWh}$ $=152,824 \mathrm{kWh}$

The treatment pond aerators require $152,824 \mathrm{kWh} / \mathrm{yr}$ or approximately $71 \%$ of the total plant energy consumption.

Table 8.4: Aerator and microfilter energy estimates and costs at $\$ 0.173 / \mathrm{kWh}$ per year during the months of March 2009 and March 2012.

Aerator Microfilter Total

$\begin{array}{cccc}\begin{array}{c}\text { Annual Energy } \\ \text { Consumption } \\ (\mathrm{kWh} / \mathrm{yr})\end{array} & 152,824 & 42,854 & 195,678 \\ \text { Cost }(\$ / \mathrm{yr}) & 26,439 & 7,371 & 33,810\end{array}$




\subsection{Efficiency}

To compare the WWWTP to other methods of wastewater treatment, a study conducted by PG\&E in 2003 (Benschine et al. 2003) of several typical wastewater treatment plants with activated sludge treatment processes will be used as a baseline. These plants used activated sludge for $\mathrm{BOD}_{5}$ removal and various conventional methods for TSS removal. Discharge requirements were less strict than those at the WWWTP. The PG\&E study considered five typical activated sludge plants around the country and determined the energy costs of the activated sludge processes. The energy values explored in this section regarding the PG\&E study include only the activated sludge process. The study determined an average treatment efficiency of $0.0013 \mathrm{kWh}$ per gallon treated $(1,395 \mathrm{kWh} / \mathrm{MG})$. Using the average WWWTP electricity cost of 17 cents per $\mathrm{kWh}$ taken from the PG\&E billing table, a power cost for the average activated sludge plant was 0.024 cents per gallon $(\$ 237 / \mathrm{MG})$. Table 8.4 compares the WWWTP and the activated sludge plants involved in the PG\&E study.

Table 8.5: Summary of the performance of WWWTP and those treatment plants included in the study by PG\&E (Benschine et al. 2003).

\begin{tabular}{cccc}
\hline & Ponds & Pall Aria AP Microfilter & Activated sludge \\
\hline Average Flow & 19,370 gal/day & 13,740 gal/day & $14 \mathrm{MGD}$ \\
Energy intensity & 24,065 & 8,545 & 1,395 \\
$(\mathrm{kWh} / \mathrm{MG})$ & & & 237 \\
Cost $(\$ / \mathrm{MG})$ & 4,139 & 1,470 & \\
\hline
\end{tabular}

The plants using activated sludge for $\mathrm{BOD}_{5}$ removal use about 20 times less energy and cost less to operate than the WWWTP. However, the vast difference in scale between the activated sludge plants and the WWWTP make the comparison imperfect. Discharge requirements at WWWTP are also much more stringent than those required of the activated sludge plants. 
Weekly averages and maxima are required to be three times lower at the WWWTP than at the activated sludge plants used in the PG\&E study. Since BOD treatment limits are achieved after Pond A, aeration performed after Pond A is not contributing to BOD removal. It might, however, be affecting Pond C TSS concentrations. Loading conditions of the WWWTP are much lower than those used in the PG\&E study. Higher loading conditions at the WWWTP are expected to raise treatment flow and lower treatment cost per MG. Future higher loading to the WWWTP will most likely increase the efficiency of the plant. Lowering the aeration is also recommended to lower the cost of treatment operation. 


\section{CHAPTER 9: CONCLUSIONS}

Based on the present study, the following points can be concluded about the WWWTP regarding the performance and conditions of the plant.

1. The ponds alone treated $\mathrm{tBOD}_{5}$ to well below the limit of $10 \mathrm{mg} / \mathrm{L}$ (Table 9.1). The pond system provided the required tBOD removal given the current low wastewater load.

2. The plant treated TSS to below the limit of $10 \mathrm{mg} / \mathrm{L}$ (Table 9.1). Treatment ponds reduced TSS to $42.5 \mathrm{mg} / \mathrm{L}$. The microfiltration unit was able to handle the Pond C TSS load, lowering TSS to $1.5 \mathrm{mg} / \mathrm{L}$ without excessive cleaning or fouling.

3. $\mathrm{pH}$ has on occasion fallen outside the limit set by the RWQCB but was corrected by the next monthly report.

4. Total ammonia nitrogen was decreased to an average of $1.61 \mathrm{mg} / \mathrm{L}$.

5. Sludge accumulated at a rate at the high end of typical for aerobic treatment ponds. However, this result is for the first 3 years of operation and, in the longer term, sludge consolidation may decrease this rate.

6. The microfiltration unit has experienced no observable permanent fouling since operation commenced. The TSS loading rate on the microfilters averaged 3.44 gram per $\mathrm{m}^{2}$ membrane surface per day of operation, and flux averaged $80.9 \mathrm{~L} \mathrm{per}^{2}$ per day of operation.

7. The WWWTP is under-loaded. At the current flow rates, the WWWTP treats municipal wastewater with 20 times greater electrical intensity than traditional large activated sludge plants (Table 8.4). At build-out, the Woodlands community will provide higher waste loads, and the WWWTP should perform at better efficiencies to provide 
unrestricted reuse-quality treatment wastewater. A reduction in aerator use may increase the efficiency of treatment at the WWWTP considerably.

When build-out occurs, a greater understanding of the performance of a microfiltration system following an algae pond system can be obtained. Because the influent flow is so low, comparisons to larger facilities is unreliable. When a more accurate comparison to larger systems is available, the use of treatment ponds and microfiltration to produce reusable water can be greater understood and applied for the greater sustainability of the world's water supply.

Table 9.1: Treatment pond and microfilter performance of $\mathrm{BOD}_{5}$ and TSS and associated electrical costs of operation at the WWWTP from March 2009 and March 2012.

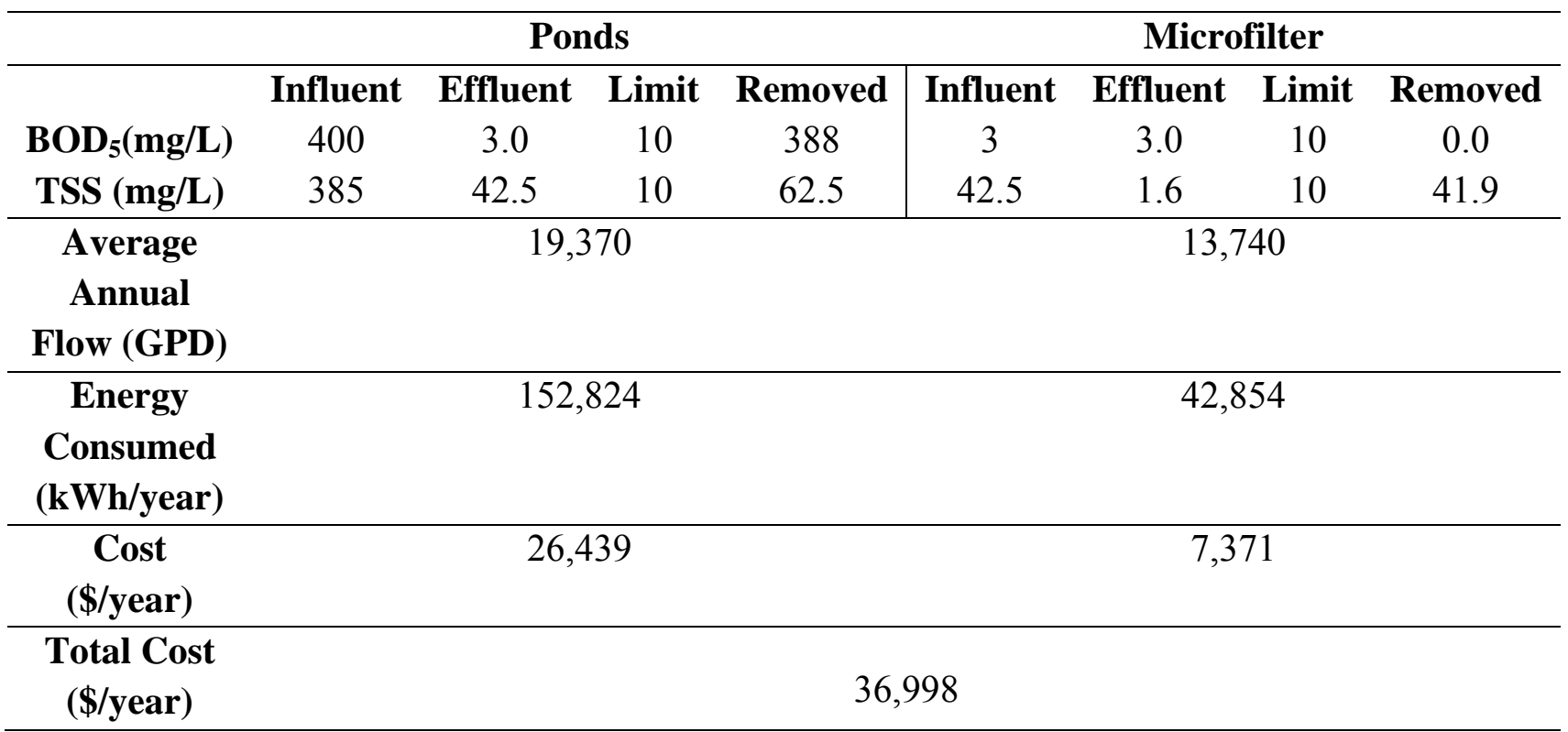




\section{REFERENCES}

Ahn, K., and K. Song. "Treatment of Domestic Wastewater Using Microfiltration for Reuse of Wastewater1." Desalination 126.1-3 (1999): 7-14. Print.

Benschine, Kathy, Stephen Fok, Carol Harty, Jayne Ng, and Patsy Dugger. Municipal Wastewater Treatment Plant: A Baseline Study. Rep. SAN FRANCISCO: M/J Industrial Solutions, (2003). Print.

"Bidorbuy Mobile Site - Powered by Kayako Fusion Help Desk Software." Bidorbuy Mobile Site Powered by Kayako Fusion Help Desk Software. N.p., n.d. Web. 26 Aug. 2012. $<$ http://support.bidorbuy.co.za/index.php?/Knowledgebase/Article/View/158/2/bidorbuy-mobilesite>.

Fabris, R., E. Lee, C. Chow, V. Chen, and M. Drikas. "Pre-treatments to Reduce Fouling of Low Pressure Micro-filtration (MF) Membranes." Journal of Membrane Science 289.1-2 (2007): 231-40. Print.

Farnsworth, Richard K., and Edwin S. Thompson. Mean Monthly, Seasonal, and Annual Pan Evaporation for the United States. Washington, D.C.: U.S. Dept. of Commerce, National Oceanic and Atmospheric Administration, National Weather Service, (1983). Print.

Good Water Company Santa Fe: Products/Green Options." Good Water Company Santa Fe: Products/Green Options. N.p., n.d. Web. 15 Nov. 2012. $<$ http://goodwatercompany.com/Products/Green_Options/index.html

Grönlund, Erik, Anders Klang, Stefan Falk, and Jörgen Hanæus. "Sustainability of Wastewater Treatment with Microalgae in Cold Climate, Evaluated with Emergy and Socio-ecological Principles." Ecological Engineering 22.3 (2004): 155-74. Print. 
Hatt, J.w., E. Germain, and S.j Judd. "Precoagulation-microfiltration for Wastewater Reuse." Water Research (2011). Print.

Herzberg, Moshe, David Berry, and Lutgarde Raskin. "Impact of Microfiltration Treatment of Secondary Wastewater Effluent on Biofouling of Reverse Osmosis Membranes." Water Research 44 (2009): 167-76. Print.

Ho, Chia-Chi, and Andrew L. Zydney. "Effect of Membrane Morphology on the Initial Rate of Protein Fouling during Microfiltration." Journal of Membrane Science 155.2 (1999): 261-75. Print..

Lim, A. "Membrane Fouling and Cleaning in Microfiltration of Activated Sludge Wastewater." Journal of Membrane Science 216.1-2 (2003): 279-90. Print.

Metcalf and Eddy, Franklin L. Burton, and George Tchobanoglous. Wastewater Engineering: Treatment, Disposal, and Reuse. New York: McGraw-Hill, (1991). Print.

MWH, and John C. Crittenden. Water Treatment Principles and Design. Hoboken, N.J: J. Wiley, 2005. Print.

Nelson, K. "Sludge Accumulation, Characteristics, and Pathogen Inactivation in Four Primary Waste Stabilization Ponds in Central Mexico." Water Research 38.1 (2004): 111-27. Print.

Nohmi, Fuji T., and Kawasaki T. Yamada. Polyvinylidene Flouride Type Resin Hollow Filament Microfilter and Process For Producing the Same. Asahi Kasei Kogyo Kabushiki Kaisha, assignee. Patent 4399035. 16 Apr. 1981. Print.

Oswald, William J., and Harold B. Gotaas. "Photosynthesis in Sewage Treatment." American Society of Civil Engineers (1955): 73-105. Print. 
Oswald, William J., Clarence G. Golueke, and Robert W. Tyler. "Integrated Pond Systems for Subdivisions." Water Pollution Control Federation (1966): 1289-304. Print.

Oswald, William J. "Advanced Integrated Wastewater Pond Systems." ASCE Convention San Francisco (1990): 73-81. Print.

US. EPA (2003). Clean Watersheds Needs Survey 2000 Report to Congress, U.S. Environmental Protection Agency.

US. EPA. Membrane Filtration Guidance Manual: Overview and Summary (2005). Print.

Wang, D., K. Li, and W. K. Teo. "Preparation and Characterization of Polyvinylidene Fluoride (PVDF) Hollow Fiber Membranes." Journal of Membrane Science 163 (1999): 211-20. Print.

Xing, W., H. H. Guo, A. Listowski, and P. Cullum. "Optimization of an Integrated Sponge-Granular Activated Carbon Fluidized Bed Bioreactor as Pretreatment to Microfiltration in Wastewater Reuse." Bioresource Technology 113 (2012): 214-18. Print. 


\section{APPENDIX}

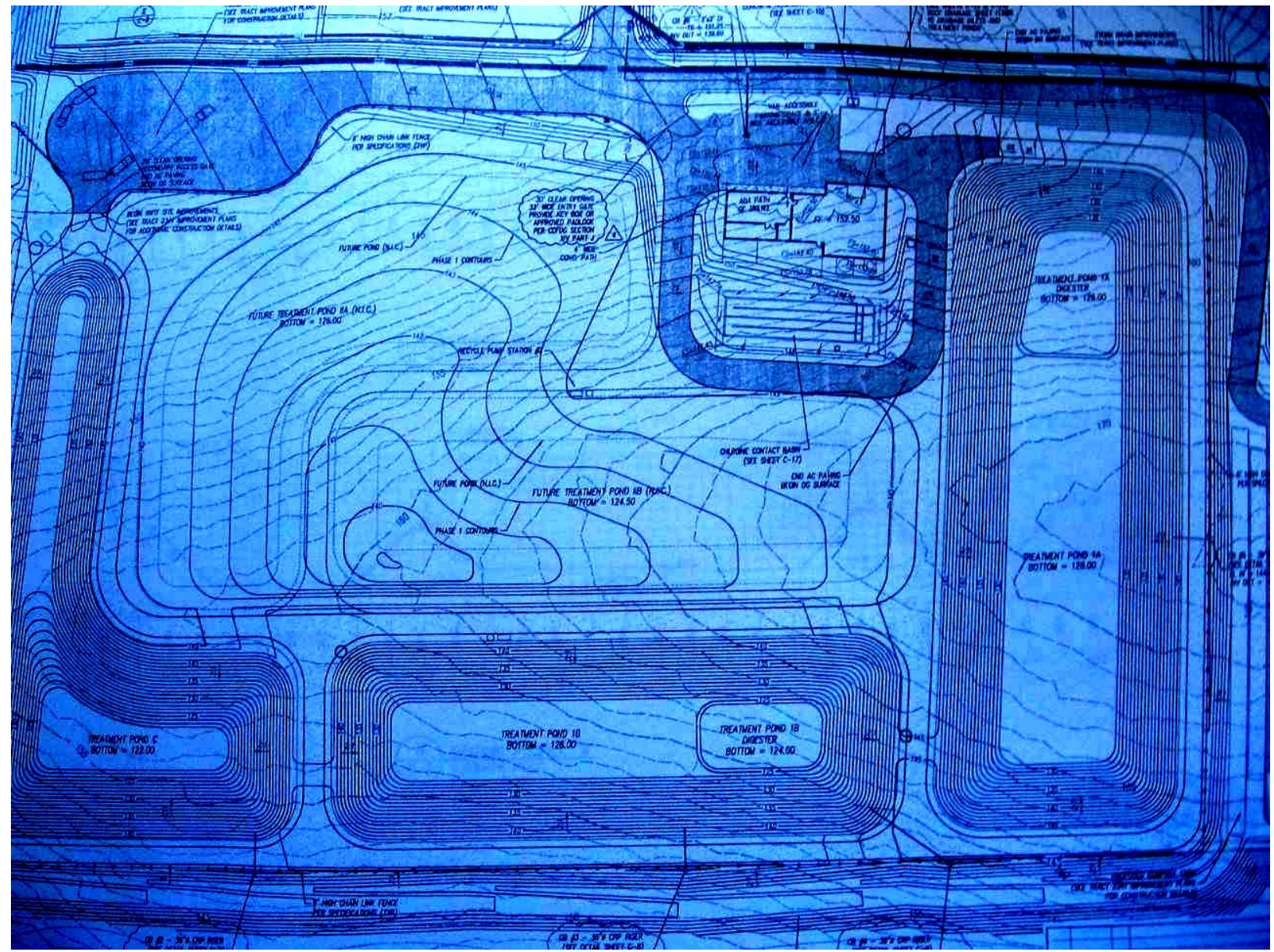

Figure A.1: Topographical plan view Woodlands Wastewater Treatment Plant. 


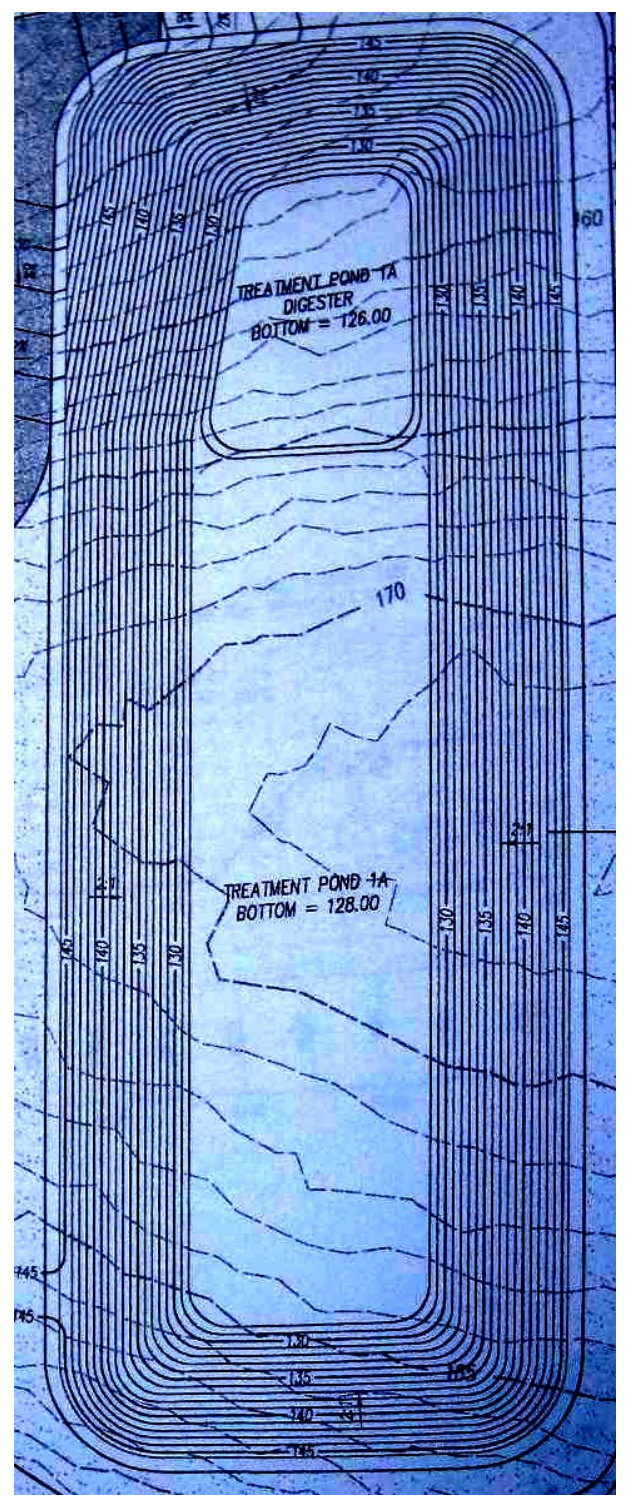

Figure A.2: Elevation plan view of Pond A. Digester floor and pond floor elevations are displayed on image 


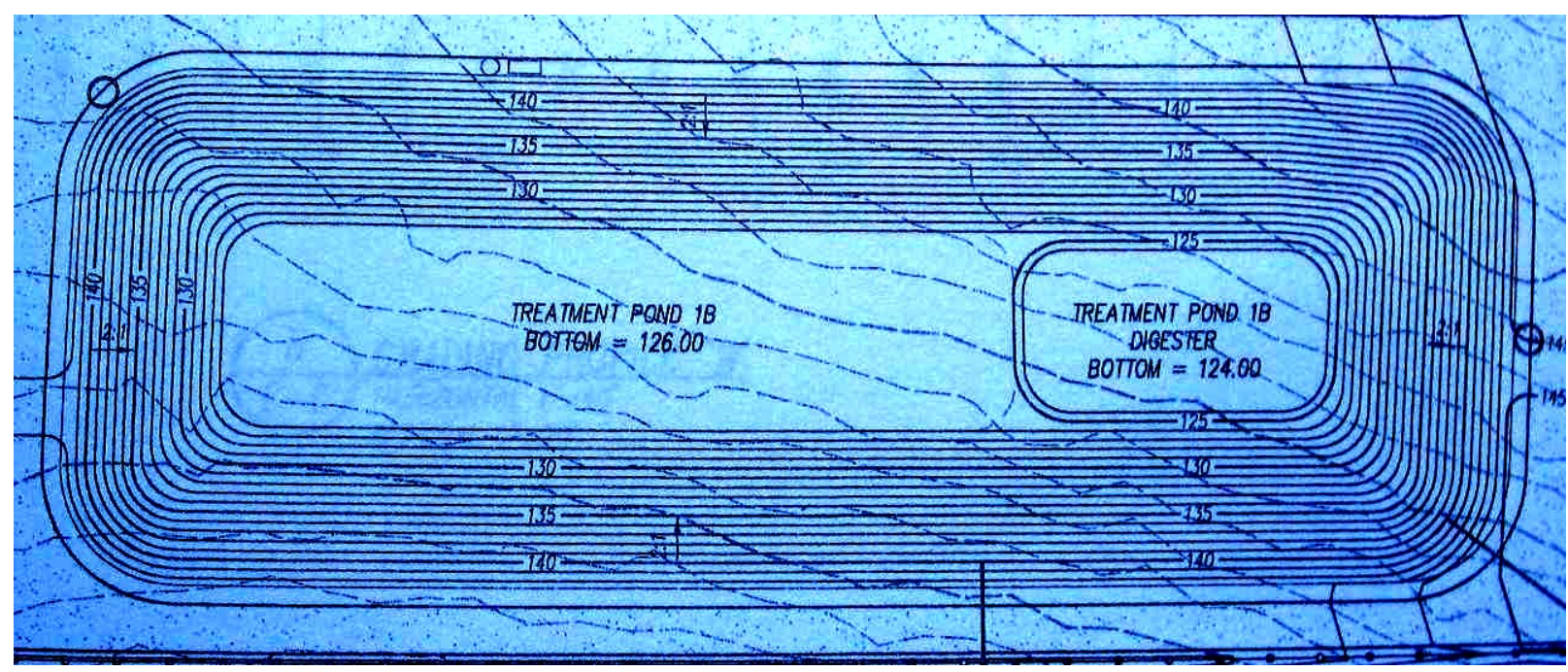

Figure A.3: Elevation plan view of Pond B. Digester floor and pond floor elevations are displayed on image 


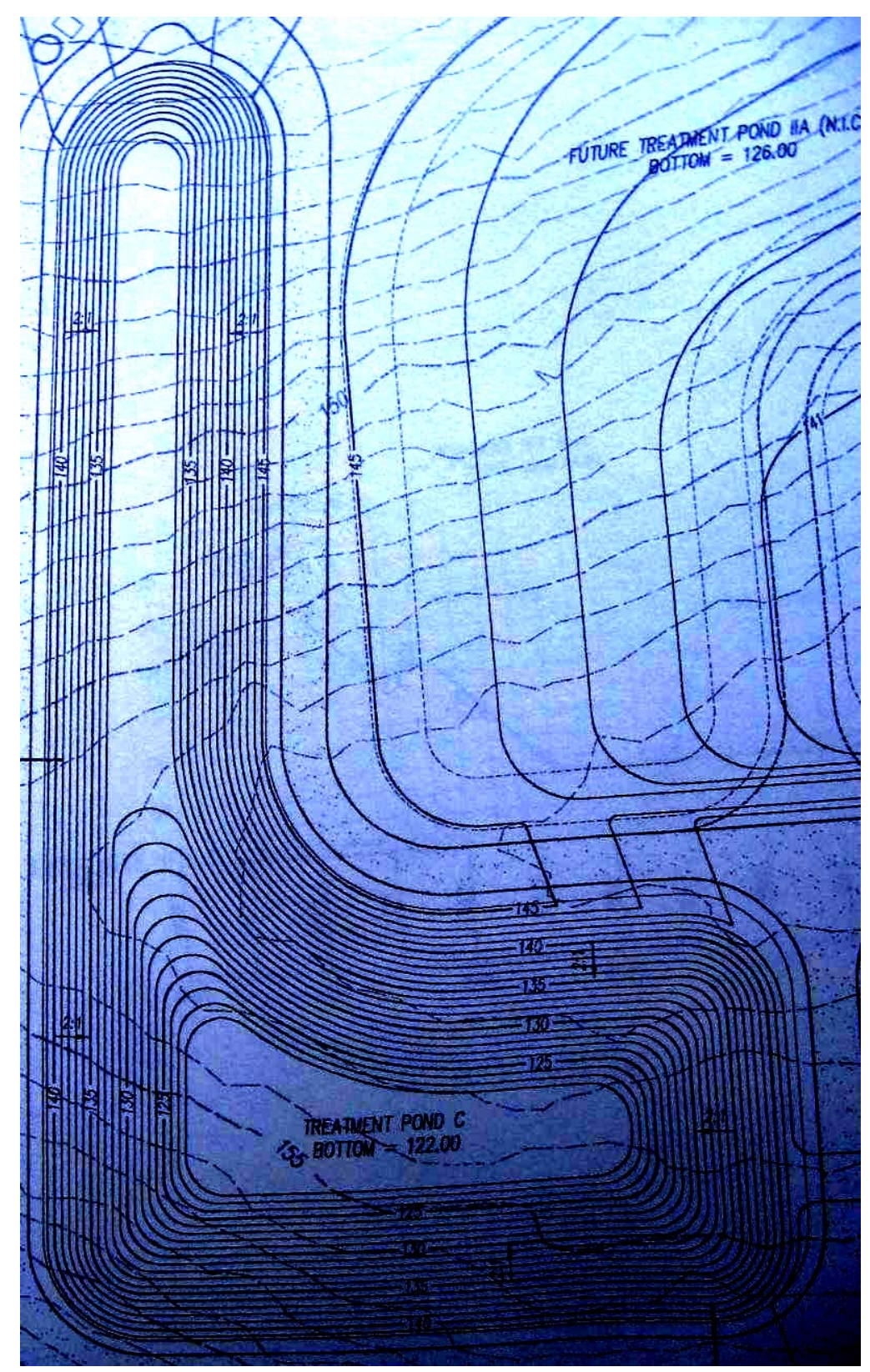

Figure A.4: Elevation plan view of Pond C. Pond floor elevations is displayed on image 


\section{PALL Water Processing}

Pall Aria AP-Series Water Treatment Systems Pall Aria"AP-Series Water Treatment Systems are specifically designed to meet the drinking water treatment requirements of small communities. Aria systems use uniquely designed Pall Microza* membrane modules in a hollow fiber configuration to remove the following contaminants from surface and ground water sources:

- Turbidity

- Bacteria

- Cysts and Oocysts

- Iron and Manganese

- Arsenic

Each $0.1 \mu \mathrm{m}$ hollow fiber module provides high active surface area (538ft $\left.{ }^{2}-50 \mathrm{~m}^{2}\right)$. The hollow fiber modules in the Aria system are highly permeable resulting in high water production rates.

Pall's dedication to simplified process design and control logic has produced a family of systems that are characterized by:

- Full Systern NSF 61 Certification

- Long Service Life Hollow Fiber Membranes

- Operator Friendly Control Interface

- Simple Clean-In-Place Operation

- High Recovery

- Low Cost of Operation

- Easily Installad Modular Skids

- Compact System Footprint

- ISO 9000 Certified Manufacturing

- Optional Auxiliary Equipment

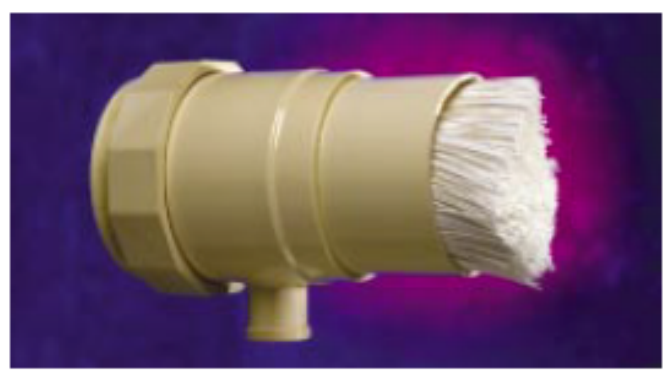

View of Hollow Fiber Membrane Module Cut-away.
Pall Aria ${ }^{\mathrm{sM}}$ AP-Series Water Treatment Systems

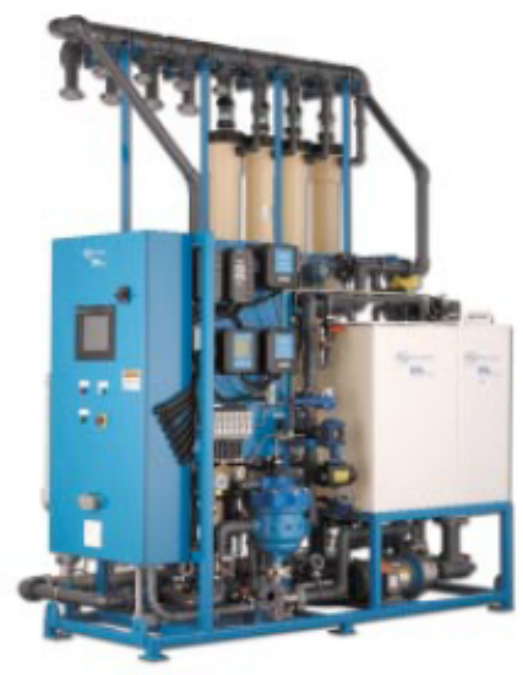

Pall Aria Water Troatment System with control panel and modules.

Aria AP-Series System Performance

Pall Microza membrane systems have been approved for potable water supply. The Aria hollow fiber membrane system was the first to receive a "full systern" certification in accordance with ANSI / NSF 61 Specifications.

Extensive testing has been done across the USA including:

- University of New Hampshire - Stoney Creek, VA

- Croton Reservoir, NY

- Westover, PA

- Highland Reservoir, PA

- Caney, KS

- Meeteetse Reservoir, WY

- Kerriville, CA

- Oregon Parks Department

- Basalt, UT

- North Slope Borough WTP, AK • Crested Butte, CO

- Youngs River, OR

- Hobart, NY

Site testing confirmed Pall Aria Water Treatment Systems meet or exceed EPA standards for safe drinking water, such as the requirement of the Surface Water Treatment Rule (as amended December 16, 1998).

Micraza is a trademank of Asahi Kesei Corporation.

Filtration. Separation. Solution. sa

Figure A.5: Pall Aria AP-4 data sheet 
Table 1: Pall Membrane Microbial and Particulate Removal

\begin{tabular}{ll}
\hline Contaminants & Typical Removal" \\
\hline Giardia & $>6 \mathrm{log}$ \\
Cryptosponidium & $>6 \mathrm{log}$ \\
MS2 coliphage or & $0.5-3 \mathrm{log}$ \\
bacteriophage & \\
Turbidity & $<0.1 \mathrm{NTU}$ \\
\hline
\end{tabular}

"Based on third party testing

Aria AP-Series System Specifications

Aria AP-Series System Components

Standard system components consist of 1 to 60 membrane modules, a feed tank, one feed pump, one reverse filtration pump, manual orvoff and automatic valving, filtrate flow meter, pressure and temperature sensors, and PLC control.

Aria AP-Series System Operation

Maximum Inlet Pressure to Module: 45 psi ( 3 bar)

Maximum Operating Temperature: $104^{\circ} \mathrm{F}$ (40 $\mathrm{C}$ )
Aria AP-Series System Specifications

Module Housing: PVC, ABS or other

Gasket: EPDM

Potting Material: Silicone and Epoxy or Urethane

Panel: NEMA 4

Tanks: Polyethylene

Piping: Lover Manifold and Air: Stainless Steel

(other piping: PVC)

Hollow Fiber Membrane: PVDF

Pumps: Horizontal Stainless Steel Centrifugal

Systern Service

Remote monitoring of system performance available as an online service. On-site service and maintenance contract also available.

Table 2: Standard Filtration Skid Specifications

\begin{tabular}{|c|c|c|c|}
\hline $\begin{array}{l}\text { Model } \\
\text { Number }\end{array}$ & $\begin{array}{l}\text { Maximum } \\
\text { Number } \\
\text { of Modules }\end{array}$ & $\begin{array}{l}\text { Maximum } \\
\text { Flow Rate } \\
\text { (gpm [m²/hr] }\end{array}$ & $\frac{\text { Footprint }(\mathbb{L} \times W \times H) \text { (Foet) }}{\text { Installed }}$ \\
\hline $\mathrm{AP}-1$ & 2 & $3-25[1-7]$ & $6 \times 2.8 \times 9.7$ \\
\hline $\mathrm{AP}-2$ & $B$ & $10-50[2.3-12]$ & $8 \times 4.1 \times 9.9$ \\
\hline$A P-3$ & 10 & $25-175[6-40]$ & $10 \times 6.9 \times 10.3$ \\
\hline $\mathrm{AP}-3 \mathrm{x}$ & 20 & $25-175[6-40]$ & (1) $22.9 \times 5.7 \times 10.8$ \\
\hline $\mathrm{AP}-4$ & 36 & $50-350[15-80]$ & (1) $24 \times 6.8 \times 10.8$ \\
\hline $\mathrm{AP}-6$ & 60 & $200-700$ [45-150] & (1) $27 \times 17 \times 10.8$ \\
\hline
\end{tabular}

Process Flow Diagram for the Pall Aria AP-Series Water Treatment System

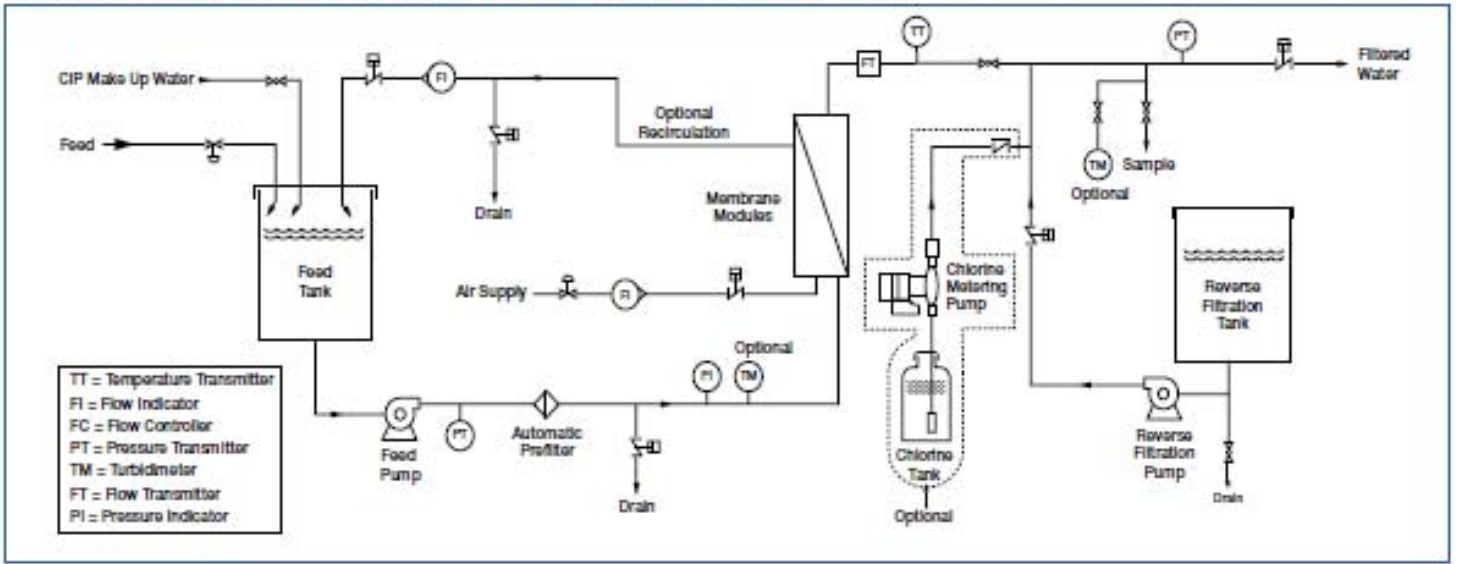

\section{PALL Water Processing}

Pall Corporation

2200 Northern Boulevard

East Hills, Naw York 11548-1289

888.873. 7255 toll free

516.484.5400 phone

516.484 .3696 fax

800.684 .7255 Select-A-FAX

516.942.0523 Select-A-FAX outside the USA

Filtration, Soparation, Solution.w

\section{Visit us on the Web at www.pall.com}

Pall Corporation has oflices and plants throughout the wond in locatione lncluang:

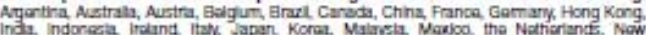

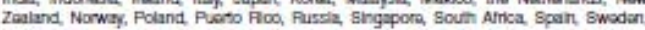

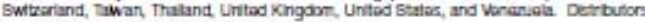
aro locatod in al major ndeatrial anas of the wotd.

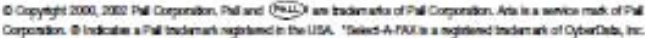

Figure A.6: Pall Aria AP-4 data sheet 